\title{
Guidelines
}

\section{An Update of Comprehensive Evidence-Based Guidelines for Interventional Techniques in Chronic Spinal Pain. Part I: Introduction and General Considerations}

Laxmaiah Manchikanti, MD, Frank J.E. Falco, MD², Vijay Singh, MD³, Ramsin M. Benyamin, MD4, Gabor B. Racz, MD5, Standiford Helm II, MD6, David L. Caraway, MD7, Aaron K. Calodney, MD, Lee T. Snook, MD ${ }^{9}$, Howard S. Smith, MD ${ }^{10}$, Sanjeeva Gupta, MD ${ }^{11}$, Stephen P. Ward, MD, FRCA, FFPMRCA ${ }^{12}$, Jay S. Grider, DO, PhD ${ }^{13}$, and Joshua A. Hirsch, MD ${ }^{14}$

From: ${ }^{\text {Pain }}$ Management Center of Paducah, Paducah, KY, and

University of Louisville, Louisville, KY; ${ }^{2}$ Mid Atlantic Spine \& Pain Physicians of Newark, Newark, DE, and Temple University Hospital, Philadelphia, PA; ${ }^{3}$ Spine Pain Diagnostics Associates, Niagara, WI; ${ }^{4}$ Millennium Pain Center, Bloomington, IL, and University of Illinois, Urbana-Champaign, IL; ${ }^{5}$ Texas Tech University Health Sciences Center, Lubbock, TX; ${ }^{6}$ The Helm Center for Pain Management, Laguna Hills, CA; 7St. Mary's Pain Relief Center, Huntington, WV; ${ }^{8}$ Neurocare Network, Tyler, TX; ${ }^{9}$ Metropolitan

Pain Management Consultants, Inc, Sacramento, CA; ${ }^{\circ} \mathrm{Alb}$ bany Medical College, Albany, NY; Bradford Teaching Hospitals

NHS, Foundation Trust, Bradford, United Kingdom; ${ }^{12}$ Brighton

and Sussex University Hospitals, NHS Trust, United Kingdom; and ${ }^{13}$ UK Healthcare Pain Services,

University of Kentucky, Lexington, KY; ${ }^{14}$ Massachusetts General

Hospital, and Harvard Medical School; Boston, MA.

Additional author affiliations and conflics of interest on P.S3O

Address Correspondence: Laxmaiah Manchikanti, M.D. 2831 Lone Oak Road

Paducah, Kentucky 42003 E-mail: drlm@thepainmd.com :

Disclaimer: There was no external funding in the preparation of this manuscript.

Conflict of interest: None.

Manuscript received: 01-10-2013 Accepted for publication: 02-12-2013

Free full manuscript: www.painphysicianjournal.com
In 2011, the Institute of Medicine (IOM) re-engineered its definition of clinical guidelines as follows: "clinical practice guidelines are statements that include recommendations intended to optimize patient care that are informed by a systematic review of evidence and an assessment of the benefit and harms of alternative care options." This new definition departs from a 2-decade old definition from a 1990 IOM report that defined guidelines as "systematically developed statements to assist practitioner and patient decisions about appropriate health care for specific clinical circumstances." The revised definition clearly distinguishes between the term "clinical practice guideline" and other forms of clinical guidance derived from widely disparate development processes, such as consensus statements, expert advice, and appropriate use criteria. The IOM committee acknowledged that for many clinical domains, high quality evidence was lacking or even nonexistent. Even though the guidelines are important decisionmaking tools, along with expert clinical judgment and patient preference, their value and impact remains variable due to numerous factors.

Some of the many factors that impede the development of clinical practice guidelines include bias due to a variety of conflicts of interest, inappropriate and poor methodological quality, poor writing and ambiguous presentation, projecting a view that these are not applicable to individual patients or too restrictive with elimination of clinician autonomy, and overzealous and inappropriate recommendations, either positive, negative, or non-committal. Consequently, a knowledgeable, multidisciplinary panel of experts must develop guidelines based on a systematic review of the existing evidence, as recently recommended by the IOM.

Chronic pain is a complex and multifactorial phenomenon associated with significant economic, social, and health outcomes. Interventional pain management is an emerging specialty facing a disproportionate number of challenges compared to established medical specialties, including the inappropriate utilization of ineffective and unsafe techniques

In 2000, the American Society of Interventional Pain Physicians (ASIPP) created treatment guidelines to help practitioners. There have been 5 subsequent updates. These guidelines address the issues of systematic evaluation and ongoing care of chronic or persistent pain, and provide information about the scientific basis of recommended procedures. These guidelines are expected to increase patient compliance; dispel misconceptions among providers and patients, manage patient expectations reasonably; and form the basis of a therapeutic partnership between the patient, the provider, and payers.

Key words: Evidence-based medicine (EBM), comparative effectiveness research (CER), clinical practice guidelines, systematic reviews, meta-analysis, interventional pain management, evidence synthesis, methodological quality assessment, clinical relevance, recommendations.

Pain Physician 2013; 16:S1-S48 
H ealth care research, practice, and policy focus on improving the organization, delivery, and outcomes of care (1). Critical to achieving these objectives is the need for guidance based on currently available knowledge generated through research, in combination with professional experience and consideration of each individual patient (2-15). Thus, the emphasis on evidence synthesis and development of guidelines continues to grow. In 2011, the Institute of Medicine (IOM) re-engineered its definition of clinical guidelines (16). According to the new definition, "clinical practice guidelines are statements that include recommendations intended to optimize patient care that are informed by a systematic review of evidence and an assessment of the benefits and harms of alternative care options." The new definition departs from a 1990 IOM report, which defined guidelines as, "systematically developed statements to assist practitioner and patient decisions about appropriate health care for specific clinical circumstances" (17).

The new definition provides a clear distinction between the term "clinical practice guideline" and other forms of clinical guidance derived from widely disparate development processes, such as consensus statements, expert advice, and appropriate use criteria. In addition, the new definition also underscores systematic review and both benefits and harms assessment as essential components of clinical practice guidelines. Although the IOM committee recognized that other forms of clinical guidance may have value, addressing the other forms was considered to be beyond the scope of the report on clinical practice guidelines. In addition, the IOM committee also has acknowledged that, for many clinical domains, high quality evidence is lacking or even non-existent. Consequently, they recommended that, despite such constraints, guideline developers should still be able to produce trustworthy clinical practice guidelines if their development reflects the committee standards as described by the IOM (16).

While guidelines, along with expert clinical judgment and patient preference, are important decisionmaking tools, their value and impact remain variable due to numerous factors $(1,2)$. For example, a population-based assessment of performance on 439 recommendations for 30 conditions spanning preventive, acute, and chronic care services found that only $55 \%$ of patients in the United States received recommended care (18). In addition, the lack of adherence to practice guidelines continues to be identified worldwide across different conditions and settings of care (19-25).
Indeed, any group of individuals can designate itself as an evidence-based medicine (EBM), comparative effectiveness research (CER), or guideline group. Different groups have reviewed the same procedure or problem in interventional pain management and reached vastly different conclusions (15,25-56). Consequently, it is clear that the process of preparation of EBM or CER manuscripts and guidelines is inadequately monitored, and replication, which is the distinguishing characteristic of scientific knowledge and an essential test of the validity of any scientific statement, is essentially impossible. Multiple factors influencing guideline development include the nature of the newly recommended practice or technology itself; characteristics of health care providers; organizational capacity to collect, adapt, share, and apply evidence; system-level environmental factors; and policies dictated by governmental agencies and the insurance community $(57,58)$. These factors, however, are considered to be manifestations of the downstream of guideline development. Consequently, the application of single and combined interventions has been recommended to address these barriers and improve compliance with guideline recommendations, even though their impact can be variable and inconsistent $(2,12,13,15,59)$. Other factors are intrinsic to guidelines and perhaps best addressed at the time of guideline development. These include bias due to various conflicts of interest, variable methodological quality, inappropriate or poor writing, and ambiguous presentation, projecting a view that these are not applicable to individual patients or too restrictive, with reduction or elimination of clinician autonomy and inappropriate overzealous recommendations. The volume of guidelines currently available may be overwhelming, particularly given that recommendations for the same clinical indication may be inconsistent across different guidelines due to individual biases and conflicts of interests $(1,2,60-62)$. The IOM provided guidance for trustworthy guidelines (16), noting that they should be:

- Based on a systematic review of the existing evidence

- Developed by a knowledgeable, multidisciplinary panel of experts and representatives from key affected groups

- Considerate of important patient subgroups and patient preferences, as appropriate

- Based on an explicit and transparent process that minimizes distortions, biases, and conflicts of interest

- Clear in their explanation of the logical relation- 
ships between alternative care options and health outcomes, and provide ratings of both the quality of evidence and the strength of recommendations

- $\quad$ Reconsidered and revised as appropriate when important new evidence warrants modifications of recommendations.

As a result, researchers, clinicians, professional organizations, and governments in the United States and other countries are looking for a sensible approach to health care with practicable and replicable EBM and CER. Multiple frameworks have been developed to improve the ability to implement clinical guidelines by developing national and international standards (63-71). Even so, there are conflicting opinions about whether guidelines are a solution to rationing or politics disguised as science (63). According to Saarni and Gylling (64), EBM is often seen as a scientific tool for quality improvement, even though its application requires consideration of scientific facts along with value judgments and the cost of different treatments. Thus, guideline development depends on whether we approach the problem from the perspective of individual patients, doctors, or public health administrators. The EBM exerts a fundamental influence on certain key aspects of medical professionalism. Thus, each segment has its own interpretation and agenda, often seemingly based on factors other than science and best care for the patient. The actual value of evidence is related to the application and circumstances in which and for whom it will be used. It is also essential to remember that the value of evidence is only as good as the type of evidence reviewed, the methodology utilized, the knowledge and experience of the reviewers, and many other factors, including bias, self-interest, and financial factors. EBM begins with the assertion that it is a shift in medical paradigms and is about solving clinical problems (63). In order for clinicians to interpret the results of clinical research effectively, a formal set of rules must complement medical training and common sense (63). Thus, knowing the tools of evidence-based practice is necessary, but not sufficient, for delivering the highest quality of patient care. It therefore continues to be a challenge for EBM, CER, and interventional pain management to better integrate new scientific innovations with the timehonored craft of caring for the sick (63). Even though some have characterized EBM as a stick by which policymakers and academicians beat clinicians (65-67), there is an extensive role for EBM, CER, and clinical guidelines based on EBM in interventional pain management $(2,6$ -
$9,15,25-31)$. EBM is commonly defined as "the conscientious, explicit, and judicious use of current best evidence in making decisions about the care of individual patients" (63). The term is loosely used and can include conducting a statistical meta-analysis of accumulated research, promoting randomized clinical trials (RCTs), supporting uniform reporting styles for research, or having a personal orientation toward critical self evaluations (59). EBM was initially defined as counter to clinical experience, while more recent definitions have emphasized the complementary character of both and have aimed to improve clinical experience with better evidence (64).

In contrast, CER is defined as "the generation and synthesis of evidence that compares the benefits and harms of alternate methods to prevent, diagnose, treat, and monitor a clinical condition or to improve the delivery of care" (30).

The influence of EBM and clinical guidelines on clinical practice and health policy is enormous. However, the process of guideline development has been, and remains, essentially unregulated (68-72). Sniderman and Furberg (72) have examined the sources of guideline authority; identified major limitations of the present process; addressed the issue of conflict of interest, both for the individuals who staff the committees and the organizations that govern them; and provided suggestions for reform that may help improve the management of the process. It has been stated that critics of EBM mostly come from within the medical professions (59). In addition to the many scientific challenges related to creating sound guidelines when evidence is weak, Sniderman and Furberg (72) stress the destructive effects of standards at the local level. Consequently, in an age of mandated cost control, managed care, and resource limitation, many practitioners "in the trenches" believe that, instead of revolutionizing care, EBM threatens to bring about stagnation, bland uniformity, and denial of coverage, and has been derogatorily characterized as "cookbook medicine" (59). Ironically, EBM may also result in a lower standard of safety and economy by de-skilling practitioners and increasing costs. In contrast, supporters tend to see EBM and guidelines as a panacea for the problems of rising costs, and the inequity and variability plaguing the health care field (59). Supporters contend that individual clinicians using EBM will be able to draw upon the objective experience of many researchers working with accepted scientific standards of evidence. Thus, this evidence is related to an assessment of the 
patient's circumstances and the practitioner's clinical experience, improving efficacy by allowing providers to divert scarce resources away from ineffective clinical practices and toward practices whose effectiveness has been conclusively demonstrated. Consequently, the specific clinical recommendations that are contained within the practice guidelines must have been systematically developed by panels of experts who have access to the available evidence, have an understanding of the clinical problem, and have clinical experience with the subject procedure and the relevant research methods to make considered judgments. These panels are expected to be objective and to produce recommendations that are unbiased, up-to-date, and free from conflicts of interest.

The notion that EBM promises to create better informed patients and clinicians by offering collectively agreed upon and publicly available information about treatment options is contradicted by a significant proportion of physician providers. In practice, EBM clinical practice guidelines are created by a small group of interested parties. Even so, there has been an explosion in the development of clinical practice guidelines, as well as the literature focusing on EBM and CER, all of which is unregulated and unchecked.

Appropriately developed guidelines must incorporate validity, reliability, reproducibility, clinical applicability and flexibility, clarity, development through a multidisciplinary process, scheduled reviews, and documentation $(17,33,73,74)$. When appropriately applied, rigorously developed guidelines have the potential to reduce undesirable practice variation, reduce the use of services that are of minimal or questionable value, increase utilization of services that are effective but underused, and target services to those populations most likely to benefit $(2-11,14,16,75-93)$.

In fact, the IOM committee on clinical practice guidelines (16) described 8 standards for developing trustworthy clinical practice guidelines, including transparency, conflict of interest, group composition, clinical practice guidelines-systematic review interception, articulation of recommendations, external review, and updating. Furthermore, the committee has focused increased attention on aspects of conflicts of interest, such as details of guideline development group exclusions; aspects of guideline group composition, including training of patient and consumer representatives in evidence appraisal, the specific nature of working relationships between systematic review teams and clinical pain guideline developers; critical steps in establishing evidence foundation for clinical recommendations and rating recommendations strength; external review of clinical practice guidelines including specifying mechanisms for ensuring public stakeholder comment; and elements essential to clinical practice guideline updating, including ongoing monitoring and review of the clinical guideline-relevant scientific literature and factors indicating the need for updates. Unlike many development methodologies, which are specific to a particular guideline development, entity, and clinical problem, the 8 standards described by the IOM provide sufficient flexibility to be applicable to all guideline development groups, whether evidence in a particular clinical area is lacking or abundant.

Finally, many barriers to evidence-based interventional pain management research exist. They include numerous factors, such as funding, time, infrastructure, patient preference, ethical issues, and, additionally, barriers associated with specific attributes related to researchers, methodologies, or interventions. It has been demonstrated that poorly or inadequately performed RCTs and meta-analysis can give rise to incorrect results and thus fail to inform clinical practice or revise policies (94-99). The same issues apply to interventional pain management. These barriers can be overcome by training, not only academicians, but also practitioners, in research methodology and data interpretation to ensure that trials are conducted correctly and evidence is adequately synthesized and disseminated. In a recent systematic review (100), multiple barriers to a general practitioner's use of EBM were illustrated. Another systematic review (101) compared the insufficient evidence for clinical practice published in 2004 by Cochrane reviews with current evidence in 2011. After analyzing 1,128 completed systematic reviews, only $45 \%$ concluded that the intervention studies were likely to be beneficial, of which only $2 \%$ recommended no further research. In total, $45 \%$ of the reviews reported that the evidence was neither beneficial nor harmful, of which $0.8 \%$ did not recommend further studies and $0.4 \%$ recommended no further research. Consequently, it was concluded that only a small number of the Cochrane collaboration systematic reviews support clinical interventions with no need for additional research.

Varma et al (102) described common pitfalls in the application of EBM, along with the reasoning behind them. The authors concluded that it is impossible to answer every potential clinical question through RCTs. Consequently, assumptions, rational thinking, logic, and reasoning are used to make recommendations. However, 
these methods may interfere with the judicious application of EBM, and may result in logical fallacies. Furthermore, the authors described that extrapolations of study content and confusing associations with causation are common pitfalls in the application of the EBM process. In addition, personal bias can be another barrier, since it may be difficult to modify despite the evidence and because keeping up with the medical literature in a busy practice can be daunting. Rosner (103) described numerous problems besetting EBM. He pointed out that the canonical pyramid of EBM excludes numerous sources of research information, such as basic research, epidemiology, and health services research. Models of EBM commonly used by third party payers have ignored clinical judgment and patient values and expectations, which together form a tripartite and more realistic guideline to effective clinical care. Compounding these issues is the fact that enhanced placebo treatments and experimentation may obscure treatment effects commonly seen in actual practice. In addition, poor systematic reviews, which comprise a significant portion of published EBM, are prone to subjective bias in their inclusion criteria and methodological scoring, which has been shown to skew outcomes. Finally, Rhee and Daramola (104) provided reassurance that there is no need to fear EBM, as it aims only to apply the best available evidence gained from the scientific method to clinical decision-making. The authors explain that, while the notion of EBM seems noble in its purpose, there are still some apprehensions and misconceptions among physicians, especially those in a predominantly surgical field. Consequently, this may also apply to interventional pain management. Developing a sophisticated understanding of the inherent biases and limitations of EBM will become increasingly important for the researcher and practicing physician as they strive to improve the rigor of their studies and produce noteworthy scientific evidence that improves health outcomes.

Recently, multiple manuscripts have described the development of clinical practice guidelines, along with the development of international standards and the updating of clinical practice guidelines $(69,70,105)$. Woolf et al (105) once again described that clinical practice guidelines are one of the foundations of efforts to improve health care. Guideline development methodology has progressed, both in terms of methods and necessary procedures, since they authored a manuscript about the topic in 1999 (106). In addition, the context for guideline development has changed with the emergence of guideline clearinghouses and large-scale guideline pro- duction organizations, such as the Agency for Healthcare Research and Quality (AHRQ) (11) and the National Institute for Health and Clinical Excellence (NICE) (107). The authors discussed issues related to identifying and synthesizing evidence: deciding what type of evidence and outcomes to include in guidelines; integrating values into a guideline; incorporating economic considerations; synthesizing, grading, and presenting evidence; and moving from evidence to recommendations (105). These recommendations are similar to the statements made by the IOM (16). In addition, there has also been a movement toward international standards for clinical practice guidelines (70). The development of guidelines within coordinated programs can facilitate the achievement of quality standards by enabling the efficient sharing of resources and expertise (108). International collaboration offers additional opportunities to enhance guideline development. Standards for guideline development can help organizations assume that recommendations are evidence-based and can help users identify high-quality guidelines. Several groups, such as the IOM (16), the World Health Organization (WHO) (109), NICE (107), the Scottish Intercollegiate Guideline Network (SIGN) (110), the National Health and Medical Research Council (NHMRC) (111), many medical societies, and others, have proposed standards for guideline developers. It is also noteworthy that the IOM's recent reports identifying criteria for trustworthy clinical practice guidelines and systematic reviews $(16,112)$ have received both praise and criticism. Much of the concern about the IOM's criteria centers on the feasibility of implementing the long list of criteria and the application of these criteria to diverse settings (113). The same criticism applies to the international network of various guidelines where clinicians, patients, and other stakeholders struggle with numerous and sometimes contradictory guidelines of variable quality (108). Qaseem et al (70) proposed a set of key components for guideline development addressing panel composition, the decision-making process, conflicts of interest, guideline objectives, development methods, evidence review, basis of recommendation, ratings of evidence and recommendations, guideline review, the updating process, and funding.

Alonso-Coello et al (69) published insight from an international survey in reference to updating clinical practice guidelines. This appears to be the first study to describe the process of updating clinical practice guidelines. They concluded that there is an urgent need to develop rigorous international standards for updating 
clinical practice guidelines and minimizing the duplication of efforts internationally.

\subsection{Definitions}

\subsection{Chronic Pain}

Chronic pain is defined as a complex and multifactorial phenomenon with pain that persists 6 months after an injury and/or beyond the usual course of an acute disease or a reasonable time for a comparable injury to heal, that is associated with chronic pathologic processes that cause continuous or intermittent pain for months or years, that may continue in the presence or absence of demonstrable pathology and may not be amenable to routine pain control methods with healing never occurring $(42,114)$.

\subsection{Interventional Pain Management}

The National Uniform Claims Committee (NUCC) (115) defined interventional pain management as the discipline of medicine devoted to the diagnosis and treatment of pain and related disorders by the application of interventional techniques in managing subacute, chronic, persistent, and intractable pain, independently or in conjunction with other modalities of treatments.

\subsection{Interventional Techniques}

The Medicare Payment Advisory Commission (MedPAC) (116) described interventional techniques as minimally invasive procedures, such as needle placement of drugs in targeted areas, ablation of targeted nerves, and some surgical techniques, such as discectomy and the implantation of intrathecal infusion pumps and spinal cord stimulators.

\subsection{Evidence-based Medicine}

EBM is defined as a conscientious, explicit, and judicious use of current best evidence in making decisions about the care of individual patients (64).

\subsection{Comparative Effectiveness Research}

Comparative effectiveness research is defined as the generation and synthesis of evidence that compares the benefits and harms of alternative methods to prevent, diagnose, treat, and monitor a clinical condition or to improve the delivery of care (117).

\subsection{Clinical Practice Guidelines}

In 2011, the IOM committee on clinical practice guidelines defined clinical practice guidelines as state- ments that include recommendations intended to optimize patient care that are informed by a systematic review of evidence and an assessment of the benefits and harms of alternative care options (16).

\subsection{Systematic Reviews and Meta-analyses}

A systematic review is defined as "the application of scientific strategies that limit bias by the systematic assembly, critical appraisal, and synthesis of all relevant studies on a specific topic" $(118,119)$.

The IOM described a systematic review as a scientific investigation that focuses on a specific question and uses explicit, prespecified scientific methods to identify, select, assess, and summarize the findings of similar but separate studies (112).

Meta-analysis, in contrast to a systematic review, is the statistical pooling of data across studies to generate a summary (pooled estimates of effects) (119).

The IOM defines meta-analysis as the progression of a systematic review to include quantitative synthesis, depending on the available data (112).

\subsection{Randomized Controlled Trials}

An RCT is defined as any research study that randomly assigns human participants or groups of humans to one or more health-related interventions versus a placebo to evaluate the effects on health outcomes (120-122).

\subsection{Observational Studies}

An observational study is defined as an etiologic or effectiveness study, a cross-sectional study, a case series, a case-control design, a design with historical controls, or a cohort design (123).

\subsection{Diagnostic Studies}

A diagnostic study is a study of diagnostic accuracy, in which results from one or more tests are compared with the results obtained with the reference standard on the same subject (124).

\subsection{Basic Considerations of Guidelines for Interventional Techniques}

\subsection{Purpose}

Evidence-based clinical practice guidelines for interventional techniques in the management of chronic spinal pain are statements developed to improve the quality of care, patient access, treatment outcomes, appropriateness of indicated and medically necessary care, 
and efficiency and effectiveness, as well as achieve cost containment by improving the cost-benefit ratio (42).

\subsection{Focus}

These updated and revised guidelines focus on a range of interventions that are the essential elements of the effective management of chronic spinal pain.

\subsection{Objectives}

The objectives of the American Society of Interventional Pain Physician's (ASIPP) updated guidelines for interventional techniques are to provide a set of recommendations that can support existing and future guidelines by:

The objectives of ASIPP's updated guidelines for interventional techniques are to provide a set of recommendations that can support existing and future guidelines by:

- $\quad$ Providing strategies to manage chronic spinal pain and/or its consequences in the general populations to improve the quality of clinical care

- Providing recommendations that are generally acceptable to a wide range of specialties and agencies

- Developing methods that are sound and transparent and highlight areas where deficiencies in knowledge merit further research;

- Utilizing a process that is valid, reliable, reproducible, clinically applicable, and flexible, in conjunction with a scheduled review

- Systematically assessing the clinical and cost effectiveness of treatments and management strategies with an evidence-based approach through the use of systematic reviews, existing evidence-based guidelines, and individual clinical studies

- Increasing compliance, dispelling misconceptions, contributing to appropriate patient expectations, and facilitating an enhanced relationship between patients, physicians, and payers.

\subsection{Population and Preferences}

The population covered by these guidelines includes all patients suffering from chronic spinal pain who are eligible to undergo commonly utilized and effective interventional technique(s). The treatment plan, evidence, patient preferences, and risk-benefit ratio must all be taken into consideration.

\subsection{Implementation and Review}

The following dates for implementation and review were established:
- $\quad$ Effective date - January 1, 2013

- $\quad$ Expiration date - December 31, 2015

- $\quad$ Scheduled review - April 2014

\subsection{Application}

While these guidelines may be applied by any specialty, they are specifically intended for use by interventional pain physicians. These guidelines do not constitute inflexible treatment recommendations. It is expected that a provider will establish a plan of care on a case-by-case basis, taking into account an individual patient's medical condition, personal needs, and preferences, and the physician's experience. Based on an individual patient's needs, treatment different from that outlined here could be warranted. Consequently, these guidelines do not represent a "standard of care."

The goal of these guidelines is to provide practitioners and payers with information to determine whether the available evidence supports the notion of a "standard" for interventional techniques. "Standard" refers to what is applicable to the majority of patients, with a preference for patient convenience and ease of administration without compromising treatment efficacy or safety. It is essential to recognize the difference between "standard" and "standard of care," as utilized as a legal definition.

\subsection{Rationale for Development of Interventional Techniques Guidelines}

\subsection{Chronic Pain}

Chronic pain is defined by the International Association for the Study of Pain (IASP) as "pain that persists beyond an expected time frame for healing (125)." Recognizing the complexity of chronic pain, ASIPP defines chronic pain as, "pain that persists 6 months after an injury and beyond the usual course of an acute disease or a reasonable time for a comparable injury to heal, that is associated with chronic pathologic processes that cause continuous or intermittent pain for months or years, that may continue in the presence or absence of demonstrable pathologies; may not be amenable to routine pain control methods; and healing may never occur" $(42,114)$. Based on multiple regulations and definitions, "chronic" may be considered to be continued pain after 90 days.

The IOM report on relieving pain in America (126) noted that, not only is the magnitude of pain in the United States astounding, with more than 100 million Americans with pain that persists for weeks to years, 
but that estimated financial costs range from $\$ 560$ billion to $\$ 630$ billion per year, with Americans constituting only $4.5 \%$ of the global population. Freberger et al (127), in an evaluation of North Carolina households conducted in 1992 and repeated in 2006, showed a significant and rapid overall increase for low back pain of $162 \%$, from $3.9 \%$ in 1992 to $10.2 \%$ in 2006 . These findings have been echoed in numerous studies. Hoy et al (128-130), in multiple publications evaluating spinal pain, showed variable prevalence with a significant recurrence of $24 \%$ to $80 \%$; a significant increase in prevalence as the population ages. Studies of the prevalence of low back and neck pain $(131,132)$ and its impact in the general population have shown $23 \%$ of patients reporting Grade II to IV low back pain with a high pain intensity and disability compared to $15 \%$ with neck pain (Fig. 1). In addition, the age-related prevalence of persistent pain has been shown to be more common in the elderly when associated with functional limitations and difficulty in performing daily life activities. Chronic persistent low back and neck pain is seen in $25 \%$ and $60 \%$ of patients, respectively, one year or longer after the initial episode.
Chronic pain is often confused with chronic pain syndrome (114). Chronic pain syndrome has been defined as a complex pain condition with physical, psychological, emotional, and social components. Even though both chronic pain and chronic pain syndrome can coexist and are defined in terms of duration and the persistence of the sensation of pain and the presence or absence of psychological and emotional components, they are 2 separate entities. Unlike chronic pain, chronic pain syndrome encompasses the added components of certain recognizable psychological and socioeconomic influences and characteristic psychological and sociological behavioral patterns. These features, which to some extent may characterize both conditions, overlap each other in multiple aspects.

Chronic pain is associated with significant economic, societal, and health outcomes (133-173). Leigh et al (143) published 1992 data for occupational injury and illness in the United States, including estimated costs, morbidity, and mortality with 6,500 job-related deaths from injury, 13.2 million non-fatal injuries, 60,300 deaths from disease, and 862,200 illnesses occurring annually in the civilian American workforce, with total

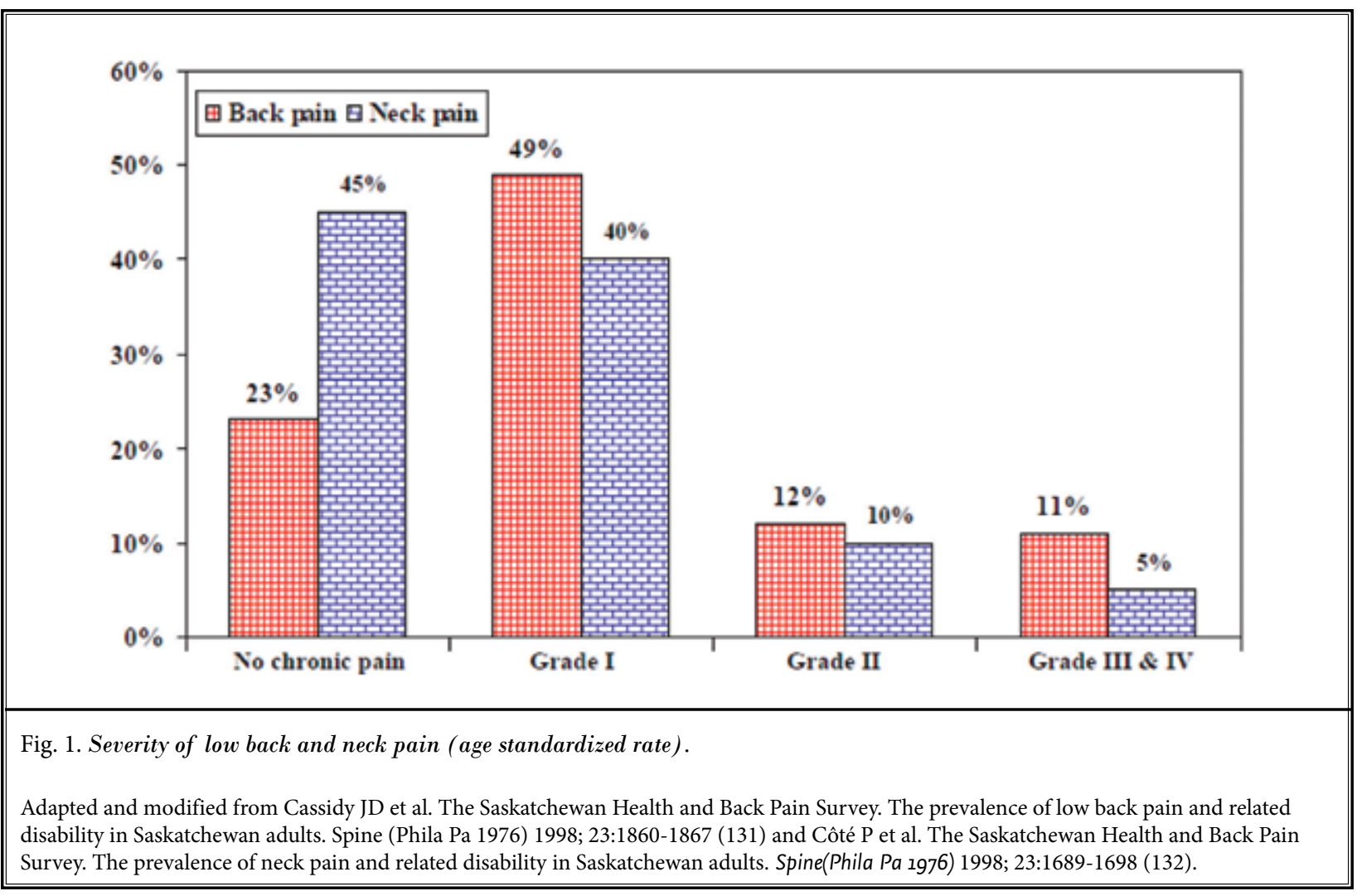


costs of $\$ 171$ billion. Martin et al (133) evaluated 2005 health care expenditures in the United States for treating back and neck problems and reported total expenditures to be approximately $\$ 86$ billion. Leigh (135), in a 2011 publication assessing data from 2007, updated their earlier study evaluating the economic burden of occupational injury and illness in the United States (143), revealing costs of $\$ 290$ billion. Furthermore, disability secondary to spinal pain is enormous (174-180). The proportion of disabled individuals, along with costs related to disability, is increasing in the United States. Disability manifests as physical and psychological impairment in chronic pain patients.

Opioid effectiveness, use, abuse, and related fatalities have been well described $(46,47,181-211)$. Evidence illustrates that opioid prescriptions have been escalating at a rapid rate, and opioid-related fatalities amount to $60 \%$ of deaths from appropriate prescriptions for chronic pain compared to $40 \%$ due to abuse, with all deaths exceeding deaths due to motor vehicle injuries. A direct correlation has been established among opioid-related deaths, treatments, and admissions, along with opioid-related sales. The opioid epidemic has not only been an issue for the United States; it is a global issue as well. Figure 2 illustrates rates of opioid pain reliever overdose deaths from 1999 to 2010 in the United States (212).

\subsection{Interventional Pain Management as an Emerging Specialty}

Increasing health care costs are a major issue across the globe (133-137). The United States spends more on health care than does any other country. Interventional pain management is no exception. Consequently, expenses in managing chronic pain and chronic spinal pain have been escalating. Martin et al (133) estimated that treatment for back and neck pain problems accounted for $\$ 86$ billion in health care expenditures in the United States in 2005. This was associated with a $65 \%$ increase in expenditures; a $49 \%$ increase in the number of patients seeking spine-related care from 1997 through 2006 was the biggest contributor to the increase in expenditures. Rates of imaging, interventional techniques, drug use, chiropractic, physical therapy, alternative complementary therapy, and surgery for spine problems have increased substantially over the past decade $(46,47,54,79-93,147-212)$. Spinal interventional techniques are thus considered one of the major components contributing to increased health care costs among patients with chronic spinal pain (79-93).

As an emerging speciality, interventional pain management faces multiple challenges that may be disproportionate compared to established medical specialities. Due to its emergent nature, interventional pain management is challenged with increasing the ap-

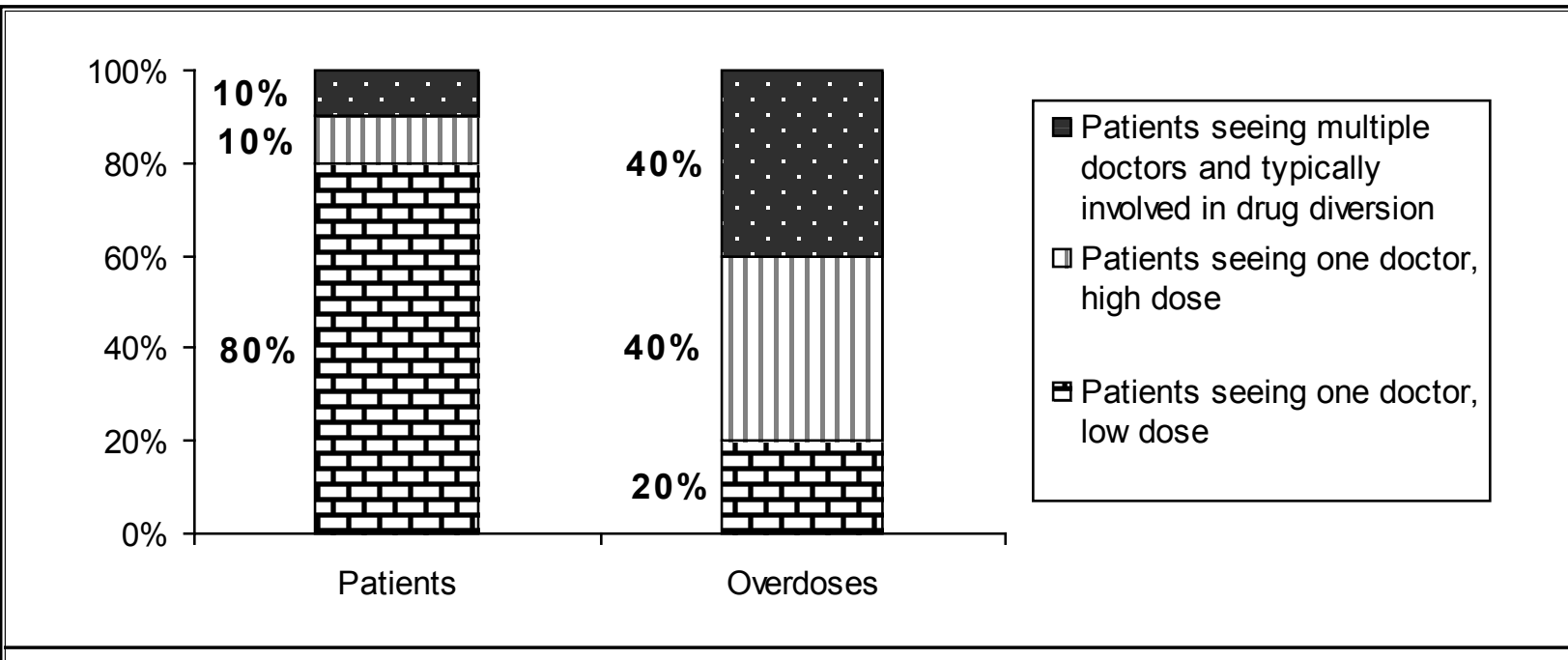

Fig. 2. Percentage of patients and prescription drug overdoses, by risk group - United States.

Source: Centers for Disease Control and Prevention. CDC grand rounds: Prescription drug overdoses - a U.S. epidemic. MMWR Morb Mortal Wkly Rep 2012; 61:10-13 (212). 
propriate utilization of effective safe techniques and identifying potentially inappropriate care that may be ineffective or unsafe. Currently, the available evidence documents a wide degree of variance in the definition and practice of medicine in general and interventional pain management in particular $(2,3,25-49)$. The application of interventional techniques by physicians of different specialties is highly variable for even the most commonly performed procedures and treatable conditions (79-93).

Abbott et al (88), in a descriptive analysis of utilization patterns between 2003 and 2007, reported that the mean number of procedures across all categories performed per patient during the 12-month inclusion period was $4.46 \pm 6.44$. They also reported that neurologists and pain management specialists were the only provider groups in which the mean number of procedures per patient exceeded the overall mean. The highest $10 \%$ of providers, which encompassed those providers performing a mean greater than or equal to 5.08 procedures per patient per year, performed $36.6 \%$ of the total spinal procedures performed. The highest $20 \%$ of providers, which encompassed those providers with a mean greater than or equal to 3.75 , accounted for $57.6 \%$ of all spinal procedures.

Manchikanti et al (87) analyzed spinal interventional pain management techniques utilization trends and Medicare expenditures from 2000 to 2008. They showed that Medicare recipients receiving spinal interventional techniques increased $107.8 \%$ from 2000 through 2008, with an annual average increase of $9.6 \%$; whereas spinal interventional techniques increased $186.8 \%$, an annual average increase of $14.1 \%$ per 100,000 beneficiaries. They concluded that there was an explosive increase in spinal interventional techniques from 2000 to 2008, which tapered off in later years. This assessment also showed that, in 2000, the majority of procedures were performed in hospital outpatient department settings (HOPDs), compared with $15.3 \%$ in ambulatory surgery centers (ASCs) and $24.3 \%$ in-office settings.. However, in 2008, office procedures $(47 \%)$ exceeded both HOPDs (28.3\%) and ASCs (24.7\%). An assessment of the expenses showed that the total allowed charges increased $300 \%$ for ASC settings, $151 \%$ for HOPD settings, and $422 \%$ for in-office settings. In addition, the charges were highest in HOPD settings and lowest in inoffice settings per patient, visit, or procedure. Charges in ASC settings declined $5 \%$ to $25 \%$, whereas in HOPD settings, they increased from $63 \%$ to $88 \%$.

In another paper, Manchikanti et al (79) assessed all interventional techniques except for implantables, continuous epidurals, intraarticular injections, trigger point and ligament injections, peripheral nerve blocks, and vertebroplasty procedures, and reported an overall increase of $228 \%$ for interventional pain management services from 2000 to 2011, and an overall increase of $177 \%$ per 100,000 Medicare beneficiaries. Annual increases with geometric average calculations were $11.4 \%$, ranging from a decrease of $1.4 \%$ to an increase of $30.3 \%$ year to year. This evaluation also showed an increase in epidural injections of $127 \%$ per 100,000 in the Medicare population, $310 \%$ for facet joint interventions and sacroiliac joint blocks, and $111 \%$ for other types of nerve blocks, with a total increase of $177 \%$ per 100,000 in the Medicare population. The number of procedures performed in the Medicare population increased from approximately 1.5 million to 5 million in 2011 (Fig. 3). This translates to approximately 20 million interventional technique procedures per year in the U.S. population. From 2000 to 2011, increases for specialties including interventional pain management, anesthesiology, physical medicine and rehabilitation, and neurology were $199 \%$ per 100,000 in the Medicare population, compared to $98 \%$ for neurological and orthopedic surgery, $166 \%$ for radiologic specialties, $48 \%$ for other physicians, and $246 \%$ for non-physician providers (Fig. 4).

The Office of Inspector General (OIG), Department of Health and Human Services (HHS), has reported startling data: Medicare Part B payments for facet joint injections have increased from $\$ 141$ million in 2003 to $\$ 307$ million in 2006 (89). During the same period, the number of Medicare claims for facet joint injections increased by $76 \%$. They also found that $63 \%$ of facet joint injection services allowed by Medicare in 2006 did not meet the Medicare program requirements, resulting in approximately $\$ 96$ million in improper payments. In addition, Medicare also allowed an additional \$33 million in improper payments for associated facility claims. Regarding errors, $38 \%$ of facet joint injection services had a documentation error, $31 \%$ a coding error, $8 \%$ did not establish medical necessity, and $14 \%$ had overlapping errors. They also showed that approximately 50\% of procedures and most of the coding errors were performed by non-interventional pain physicians.

An OIG report on transforaminal epidural injections titled "Inappropriate Medicare Payments for Transforaminal Epidural Injection Services" reported that 34\% of transforaminal epidural injection services allowed by Medicare in 2007 did not meet Medicare requirements, 


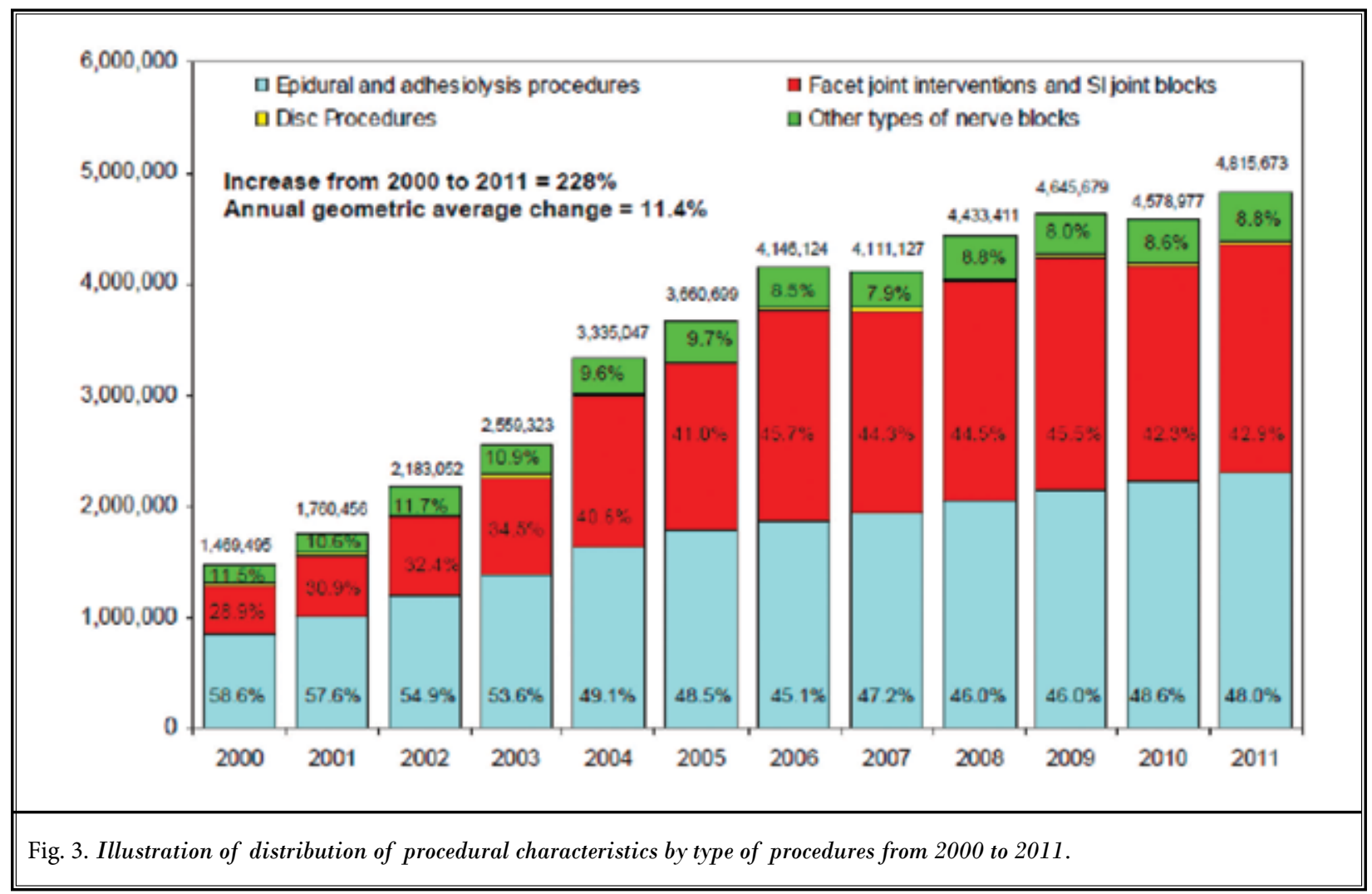

resulting in approximately $\$ 68$ million in improper payments (90). The number of Medicare physician claims for transforaminal epidural injection services increased by $130 \%$ from 2003 to 2007 . Over 295,000 Medicare beneficiaries received transforaminal epidural injection services in 2007. Nineteen percent of transforaminal epidural injection services had a documentation error, which was more likely to occur in office settings. Thirteen percent of transforaminal epidural injection services had a medical necessity error, $8 \%$ had a coding error, and $7 \%$ had overlapping errors.

\subsection{Importance}

Many of the causes of spinal pain and other chronic pain conditions are considered to be either acute recurrent problems characterized by periods of quiescence punctuated by flare-ups, or chronic diseases, like diabetes or hypertension, requiring long-term treatment with ongoing care. The importance of interventional techniques in managing chronic spinal pain has been established based on advances in imaging, neuroanatomic findings, new discoveries in chemical mediation, the development of precision diagnostic and therapeu- tic injection techniques, and reported non-operative treatment successes. Numerous guidelines, systematic reviews, Cochrane Reviews, randomized trials, and observational studies pertaining to all aspects of interventional pain management have been published (2,25-54,213-398). However, most of these are ambiguous and may not be applicable for chronic spinal pain management utilizing contemporary interventional pain techniques. Furthermore, there are quality issues related to the inclusion or exclusion of significant literature, such as observational studies.

Thus, the quality of systematic reviews, guidelines, and policies has been questioned, and concerns have been raised regarding non-applicability across populations, bias, and alleged major shortcomings with potentially harmful health care implications for patients $(2,25-54,399)$. As a result, ASIPP has developed a strict, ongoing process of evidence synthesis and guideline preparation with appropriate updating since 1999 $(25,42,46,47,400-407)$. The interventional techniques guidelines and opioid guidelines developed by ASIPP have been listed on the AHRQ/National Guideline Clearinghouse (NGC) web site $(408,409)$. 


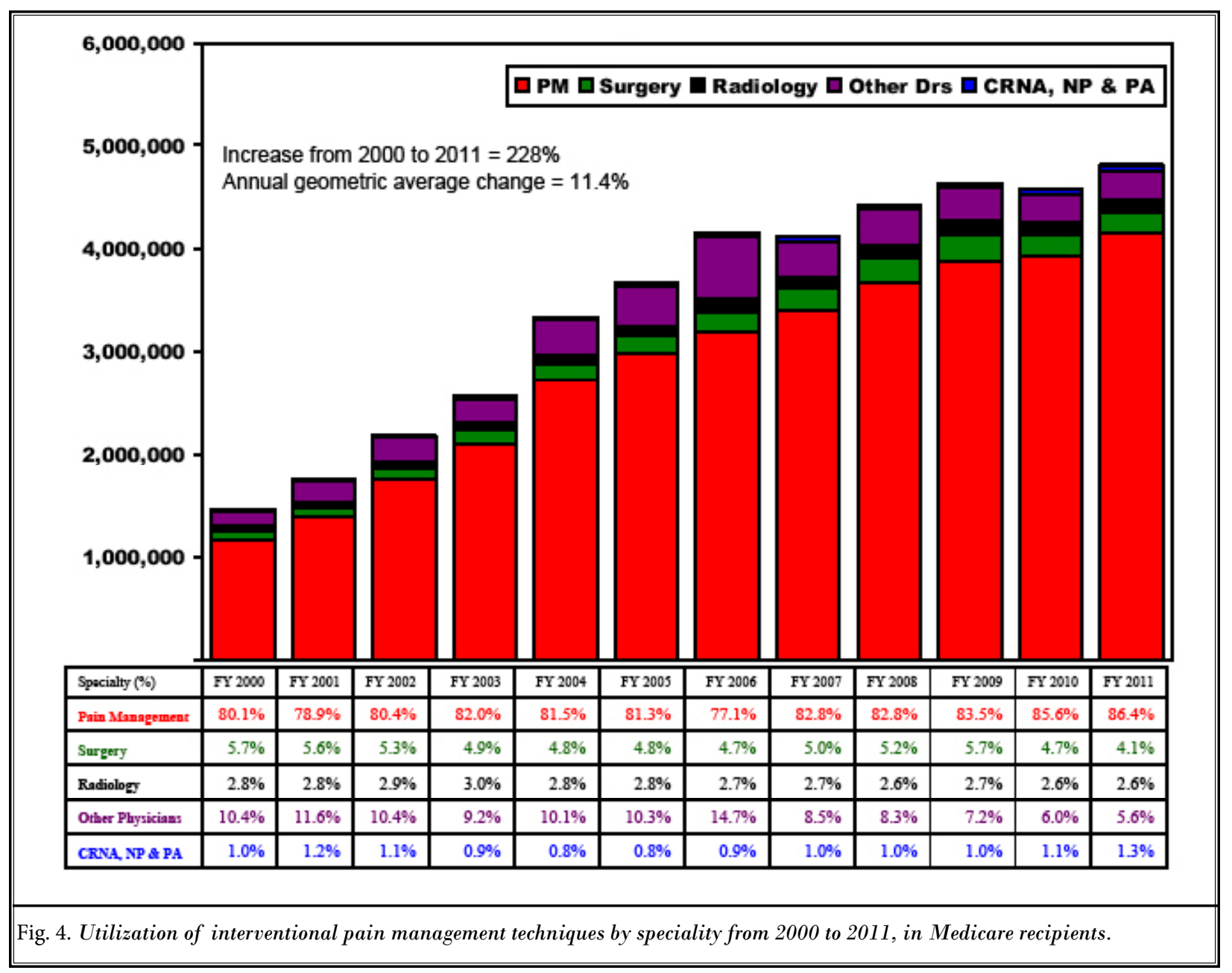

\subsection{Technology}

Diagnostic and therapeutic interventional techniques in the management of chronic spinal pain have been evaluated. These include facet joint interventions, sacroiliac joint interventions, epidural injections, lumbar epidural adhesiolysis, discography and intradiscal therapies, and implantable therapies.

\subsection{Methodology of Guideline Developiment}

In recent years, there have been substantial increases in the number of treatment alternatives available to providers and patients, the proportions of patients receiving interventional pain management services, the volume of studies describing the effectiveness (or ineffectiveness) of those options, guidelines, and systematic reviews
(2,25-54,79-83,213-398). The body of available evidence is becoming more complex, conflicting, and difficult to manage for most providers. Thus, guidelines have become a critical tool for comprehensively summarizing the available literature and organizing it in a format that is accessible to interventional pain management physicians. It has been demonstrated that systematic reviews are outdated after 2-3 years (410-412). Further, assessment and rapid development of systematic reviews have been published (413-416). Due to the wealth of emerging literature, this is especially true for specialties such as interventional pain management, where reviews may be outdated after as little as one year.

\subsection{Essentials of Guideline Development}

Several groups, including IOM, WHO, NICE, and 
NHMRC have provided appropriate guidance in preparing trustworthy guidelines. An additional source, founded in 2002, is Guidelines International Network (G-I-N) - a network of guideline developers composed of 93 organizations and 89 individual members representing 46 countries (414). This organization also has developed a set of key components for guideline development.

\subsubsection{Institute of Medicine Guidance}

While there are numerous guidelines developed by multiple organizations, most suffer from shortcomings in the guideline development process, often compounding the limitations inherent in their scientific evidentiary reference basis (16). The IOM explained that in order to be trustworthy, guidelines must be

- Based on a systematic review of existing evidence

- Developed by a knowledgeable, multidisciplinary panel of experts and representatives from key affected groups

- Considerate of important patient subgroups and patient preferences, as appropriate

- Based on an explicit and transparent process that minimizes distortion, biases, and conflicts of interest

- Clear in their explanation of logical relationships between alternative care options and health outcomes, providing ratings of both the quality of evidence and the strength of recommendations

- Reconsidered and revised as appropriate when important new evidence warrants modifications and recommendations.

The IOM also described the multiple factors commonly undermining the quality and trustworthiness of clinical practice guidelines, including:

- Variable quality of individual scientific studies

- Limitations of systematic reviews upon which clinical guidelines are based

- Lack of transparency of development groups' methodologies, particularly with respect to evidence quality and strength of recommendation appraisals

- Failure to convene multi-stakeholder and multidisciplinary guideline development groups, and resulting non-reconciliation of conflicting guidelines

- Unmanaged conflicts of interest

- Overall failure to use rigorous methodologies during development
In addition, the IOM committee noted that evidence supporting clinical decision-making and clinical practice guideline development relevant to subpopulations, such as patients with comorbidities, the socially and economically disadvantaged, and those with rare conditions, is usually absent. Overall the committee concluded that the quality of clinical practice guideline development processes and guideline developer adherence to quality standards have remained unsatisfactory and unreliable for decades. Non-standardized development results in significant variation in clinical recommendations. Even though the IOM once again depended on unreliable tools and evidence, they have formulated a new definition and also developed standards for trustworthy clinical practice guidelines (CPG). The committee's 8 proposed standards are reproduced herewith (16):

\section{STANDARD 1:}

\section{Establishing transparency}

1.1 The processes by which a CPG is developed and funded should be detailed explicitly and publicly accessible.

\section{STANDARD 2:}

\section{Management of conflict of interest (COI)}

2.1 Prior to selection of the Guideline Development Group (GDG), individuals being considered for membership should declare all interests and activities potentially resulting in $\mathrm{COI}$ with development group activity, by written disclosure to those convening the GDG.

- Disclosure should reflect all current and planned commercial (including services from which a clinician derives a substantial proportion of income), non-commercial, intellectual, institutional, and patient/public activities pertinent to the potential scope of the CPG.

2.2 Disclosure of COls within GDG

- All COI of each GDG member should be reported and discussed by the prospective development group prior to the onset of their work.

- Each panel member should explain how their COI could influence the CPG development process or specific recommendations.

2.3 Divestment

- Members of the GDG should divest themselves of financial investments they or their family members have in, and not participate in marketing activi- 
ties or advisory boards of, entities whose interests could be affected by CPG recommendations.

2.4 Exclusions

- Whenever possible GDG members should not have COI.

- In some circumstances, a GDG may not be able to perform its work without members who have COIs, such as relevant clinical specialists who receive a substantial portion of their incomes from services pertinent to the CPG.

- Members with COls should represent not more than a minority of the GDG.

- The chair or co-chairs should not be a person(s) with COI.

- $\quad$ Funders should have no role in CPG development.

\section{STANDARD 3:}

\section{Guideline development group composition}

3.1 The GDG should be multidisciplinary and balanced, comprising a variety of methodological experts and clinicians, and populations expected to be affected by the CPG.

3.2 Patient and public involvement should be facilitated by including (at least at the time of clinical question formulation and draft CPG review) a current or former patient and a patient advocate or patient/ consumer organization representative in the GDG.

3.3 Strategies to increase effective participation of patient and consumer representatives, including training in appraisal of evidence, should be adopted by GDGs.

\section{STANDARD 4:}

\section{Clinical practice guideline-systematic review intersection}

4.1 CPG developers should use systematic reviews that meet standards set by the Institute of Medicine's Committee on Standards for Systematic Reviews of Comparative Effectiveness Research.

4.2 When systematic reviews are conducted specifically to inform particular guidelines, the GDG and systematic review team should interact regarding the scope, approach, and output of both processes.

\section{STANDARD 5:}

\section{Establishing evidence foundations for and} rating strength of recommendations

5.1 For each recommendation, the following should be provided:
- An explanation of the reasoning underlying the recommendation, including:

- A clear description of potential benefits and harms.

- A summary of relevant available evidence (and evidentiary gaps), description of the quality (including applicability), quantity (including completeness), and consistency of the aggregate available evidence.

- An explanation of the part played by values, opinion, theory, and clinical experience in deriving the recommendation.

- A rating of the level of confidence in (certainty regarding) the evidence underpinning the recommendation.

- A rating of the strength of the recommendation in light of the preceding bullets.

- A description and explanation of any differences of opinion regarding the recommendation.

\section{STANDARD 6:}

\section{Articulation of recommendations}

6.1 Recommendations should be articulated in a standardized form detailing precisely what the recommended action is and under what circumstances it should be performed.

6.2 Strong recommendations should be worded so that compliance with the recommendation(s) can be evaluated.

\section{STANDARD 7:}

\section{External review}

7.1 External reviewers should comprise a full spectrum of relevant stakeholders, including scientific and clinical experts, organizations (e.g., health care, specialty societies), agencies (e.g., federal government), patients, and representatives of the public.

7.2 The authorship of external reviews submitted by individuals and/or organizations should be kept confidential unless that protection has been waived by the reviewer(s).

7.3 The GDG should consider all external reviewer comments and keep a written record of the rationale for modifying or not modifying a CPG in response to reviewers' comments.

7.4 A draft of the CPG at the external review stage or immediately following it (i.e., prior to the final draft) should be made available to the general public for comment. Reasonable notice of impending publication should be provided to interested public stakeholders. 
STANDARD 8:

\section{Updating}

8.1 The CPG publication date, date of pertinent systematic evidence review, and proposed date for future CPG review should be documented in the CPG.

8.2 Literature should be monitored regularly following CPG publication to identify the emergence of new, potentially relevant evidence and to evaluate the continued validity of the CPG.

8.3 CPGs should be updated when new evidence suggests the need for modification of clinically important recommendations. For example, a CPG should be updated if new evidence shows that a recommended intervention causes previously unknown substantial harm, that a new intervention is significantly superior to a previously recommended intervention from an efficacy or harms perspective, or that a recommendation can be applied to new populations.

Finally, the committee derived several recommendations directly relevant to the ultimate effectiveness of the 8 standards in increasing the quality and trustworthiness of CPGs and enhancing health care quality in patient outcomes. Thus, to be trustworthy, a CPG should comply with the proposed standards from 1 to 8 as shown above. The ASIPP guideline development process has followed the majority of these recommendations.

\subsubsection{Guidance from Guidelines International Network}

The G-I-N $(70,414)$ described the following key components of a high-quality and trustworthy guideline as shown in Table 1.

The 11 key components described include multiple aspects similar to other guidance:

- Composition of Guideline Development Group

- Decision-Making Process

- Conflicts of Interest

- Scope of a Guideline

- Methods

- Evidence Reviews

- Guideline Recommendations

- Rating of Evidence and Recommendations

- Peer Review and Stakeholder Consultations

- Guideline Expiration and Updating

- Financial Support and Sponsoring Organization.

Table 1. Key components of high-quality and trustworthy guidelines.

\begin{tabular}{|c|c|}
\hline Component & Description \\
\hline $\begin{array}{l}\text { Composition of Guideline } \\
\text { Development Group }\end{array}$ & $\begin{array}{l}\text { A guideline development panel should include diverse and relevant stakeholders, such as health } \\
\text { professionals, methodologists, experts on a topic, and patients }\end{array}$ \\
\hline Decision-Making Process & $\begin{array}{l}\text { A guideline should describe the process used to reach consensus among the panel members and, if } \\
\text { applicable, approval by the sponsoring organization. This process should be established before the start } \\
\text { of guideline development. }\end{array}$ \\
\hline Conflicts of Interest & $\begin{array}{l}\text { A guideline should include disclosure of the financial and nonfinancial conflicts of interest for members } \\
\text { of the guideline development group. The guideline should also describe how any identified conflicts were } \\
\text { recorded and resolved. }\end{array}$ \\
\hline Scope of a Guideline & A guideline should specify its objective(s) and scope. \\
\hline Methods & A guideline should clearly describe the methods used for the guideline development in detail. \\
\hline Evidence Reviews & $\begin{array}{l}\text { Guideline developers should use systematic evidence review methods to identify and evaluate evidence } \\
\text { related to the guideline topic. }\end{array}$ \\
\hline Guideline Recommendations & $\begin{array}{l}\text { A guideline recommendation should be clearly stated and based on scientific evidence of benefits; harms; } \\
\text { and, if possible, costs. }\end{array}$ \\
\hline $\begin{array}{l}\text { Rating of Evidence and } \\
\text { Recommendations }\end{array}$ & $\begin{array}{l}\text { A guideline should use a rating system to communicate the quality and reliability of both the evidence } \\
\text { and the strength of its recommendations. }\end{array}$ \\
\hline $\begin{array}{l}\text { Peer Review and Stakeholder } \\
\text { Consultations }\end{array}$ & Review by external stakeholders should be conducted before guideline publication \\
\hline $\begin{array}{l}\text { Guideline Expiration and } \\
\text { Updating }\end{array}$ & $\begin{array}{l}\text { A guideline should include an expiration date and/or describe the process that the guideline groups will } \\
\text { use to update recommendations. }\end{array}$ \\
\hline $\begin{array}{l}\text { Financial Support and Sponsoring } \\
\text { Organization }\end{array}$ & $\begin{array}{l}\text { A guideline should disclose financial support for the development of both the evidence review as well as } \\
\text { the guideline recommendations. }\end{array}$ \\
\hline
\end{tabular}

Source: Qaseem A, et al. Guidelines International Network: Toward international standards for clinical practice guidelines. Ann Intern Med 2012; 156:525-531 (70). 


\subsubsection{American Society of Interventional Pain Physicians Guideline Development Process}

ASIPP launched the development of practice guidelines for interventional techniques in the management of chronic pain in 1999 and published the first guideline in 2000 (400). These guidelines were developed to help practitioners by synthesizing the available evidence. The authors stated that these clinical practice guidelines for interventional techniques in the management of chronic pain were professionally developed utilizing a combination of evidence and consensus.

The synthesis of evidence, committee composition, and development process have been revised, refined, and expanded with evaluation at least once every 3 years.

ASIPP guidelines meet all 8 criteria described by the IOM (16). In developing ASIPP guidelines, all aspects from multiple guidelines were considered. ASIPP guidelines also meet the majority of the criteria described by other guidelines.

\subsection{Development of ASIPP Guidelines}

Recommendations of the IOM, which essentially incorporate all other guidance for guideline development, were applied in the preparation of ASIPP guidelines. As all of the guidelines share a similar philosophy, this guideline development process uses the IOM's 8 proposed standards (16).

\subsection{Transparency}

The ASIPP guidelines development process is a project undertaken by the Board of Directors and membership of ASIPP, a not-for-profit organization, to provide a set of recommendations that can support existing and future guidelines to provide appropriate strategies to manage chronic spinal pain and improve the quality of clinical care. Even though ASIPP is an American society, its membership consists of multiple specialties across the globe. The majority of the specialists include interventional pain physicians derived primarily from the specialties of anesthesiology, physical medicine and rehabilitation, and neurology and psychiatry.

There has been no external funding from any type of industry to support the preparation of these guidelines. All participation has been on a voluntary basis. All participants have been requested to provide their COIs.

\subsection{Management of Conflict of Interest}

Conflicts were managed by limiting the involvement of individuals with $\mathrm{COI}$ and re-evaluating the evidence provided by those with $\mathrm{COI}$, even though there was no direct funding received for this project. Consequently, we have also undertaken extensive efforts to avoid direct as well as indirect, internal, and external COI. Prior to inclusion in the guideline development group, all individuals considered for membership declared in writing all interests and activities potentially resulting in $\mathrm{COI}$ with development group activity. Disclosures reflected all current and planned commercial, including services from which a clinician derives a substantial portion of income, non-commercial, intellectual, institutional, and patient/public activities pertinent to the potential scope of the clinical practice guidelines. As there were no significant $\mathrm{COI}$ among the members, there was no necessity for divestment or exclusion. Even then, care was exercised to avoid any conflicts not disclosed by the usual disclosure procedure.

\subsection{Guideline Development Group Composition}

ASIPP convened a multidisciplinary panel of 51 experts in various fields to review the evidence and formulate recommendations for interventional techniques in managing chronic spinal pain. The panel was instructed to answer questions and develop evidence pertaining to important aspects of spinal interventional techniques. Members of the panel were also requested to develop comprehensive systematic reviews on various related subjects in preparation for the development of spinal interventional techniques guidelines (185-313). Other independent systematic reviews were also considered. The panel convened in person on 3 occasions at ASIPP workshops in Memphis, $\mathrm{TN}$, and also had 6 webinars and/or telephone conferences. The majority of participants attended multiple meetings.

The committee provided a broad representation of academic and non-academic clinical practitioners, reflecting a variety of practices and geographic areas, all with interest and expertise in interventional techniques and chronic pain management. The committee formulized the elements of the guideline preparation process, including literature searches, literature synthesis, consensus evaluation, open forum presentations, and formal endorsement by the ASIPP Board of Directors and peer review. However, there were no patients and patient advocates or patient/consumer organizations included in the guideline development process, which may be considered as a deficiency. 


\subsection{Systematic Reviews}

The IOM developed standards for systematic reviews (112). It described the function / purpose of a systematic review as a tool to identify, select, assess, and synthesize the findings of similar but separate studies and to help clarify what is known and not known about the potential benefits and harms of drugs, devices, and other health care services. Systematic reviews can be helpful for clinicians who want to integrate research findings into their daily practices, for patients to make well-informed choices about their own care, and for professional medical societies and other organizations that develop clinical practice guidelines (112). In developing standards for systematic reviews, the IOM committee defined a "standard" as "a process, action, or procedure for performing systematic reviews that is deemed essential to producing scientifically valid, transparent, and reproducible results."

IOM standards for systematic reviews (112) described multiple standards as reproduced here with modifications in numbering to conform to the text in this manuscript.

\subsection{STANDARDS FOR INITIATING A SYSTEMATIC REVIEW}

\section{STANDARD 1.1}

Establish a team with appropriate expertise and experience to conduct the systematic review

1.1.1 Include expertise in the pertinent clinical content areas

1.1.2 Include expertise in systematic review methods

1.1.3 Include expertise in searching for relevant evidence

1.1.4 Include expertise in quantitative methods

1.1.5 Include other expertise as appropriate

\section{STANDARD 1.2}

Manage bias and conflict of interest (COI) of the team conducting the systematic review

1.2.1 Require each team member to disclose potential COI and professional or intellectual bias

1.2.2 Exclude individuals with a clear financial conflict

1.2.3 Exclude individuals whose professional or intellectual bias would diminish the credibility of the review in the eyes of the intended users

\section{STANDARD 1.3}

Ensure user and stakeholder input as the review is designed and conducted

1.3.1 Protect the independence of the review team to make the final decisions about the design, analysis, and reporting of the review

\section{STANDARD 1.4}

Manage bias and COI for individuals providing input into the systematic review

1.4.1 Require individuals to disclose potential COI and professional or intellectual bias

1.4.2 Exclude input from individuals whose $\mathrm{COI}$ or bias would diminish the credibility of the review in the eyes of the intended users

\section{STANDARD 1.5}

Formulate the topic for the systematic review

1.5.1 Confirm the need for a new review

1.5.2 Develop an analytic framework that clearly lays out the chain of logic that links the health intervention to the outcomes of interest and defines the key clinical questions to be addressed by the systematic review

1.5.3 Use a standard format to articulate each clinical question of interest

1.5.4 State the rationale for each clinical question

1.5.5 Refine each question based on user and stakeholder input

\section{STANDARD 1.6}

Develop a systematic review protocol

1.6.1 Describe the context and rationale for the review from both a decision-making and research perspective

1.6.2 Describe the study screening and selection criteria (inclusion/exclusion criteria)

1.6.3 Describe precisely which outcome measures, time points, interventions, and comparison groups will be addressed

1.6.4 Describe the search strategy for identifying relevant evidence

1.6.5 Describe the procedures for study selection

1.6.6 Describe the data extraction strategy

1.6.7 Describe the process for identifying and resolving disagreement between researchers in study selection and data extraction decisions

1.6.8 Describe the approach to critically appraising individual studies 
1.6.9 Describe the method for evaluating the body of evidence, including the quantitative and qualitative synthesis strategies

1.6.10 Describe and justify any planned analyses of differential treatment effects according to patient subgroups, how an intervention is delivered, or how an outcome is measured

1.6.11 Describe the proposed timetable for conducting the review

\section{STANDARD 1.7}

Submit the protocol for peer review

1.7.1 Provide a public comment period for the protocol and publicly report on the disposition of comments

\section{STANDARD 1.8}

Make the final protocol publicly available, and add any amendments to the protocol in a timely fashion

\subsection{STANDARDS FOR FINDING AND ASSESSING INDIVIDUAL STUDIES}

\section{STANDARD 2.1}

Conduct a comprehensive systematic search for evidence

2.1.1 Work with a librarian or other information specialist trained in performing systematic reviews to plan the search strategy

2.1.2 Design the search strategy to address each key research question

2.1.3 Use an independent librarian or other information specialist to peer review the search strategy

2.1.4 Search bibliographic databases

2.1.5 Search citation indexes

2.1.6 Search literature cited by eligible studies

2.1.7 Update the search at intervals appropriate to the pace of generation of new information for the research question being addressed

2.1.8 Search subject-specific databases if other databases are unlikely to provide all relevant evidence

2.1.9 Search regional bibliographic databases if other databases are unlikely to provide all relevant evidence

\section{STANDARD 2.2}

Take action to address potentially biased reporting of research results
2.2.1 Search grey literature databases, clinical trial registries, and other sources of unpublished information about studies

2.2.2 Invite researchers to clarify information about study eligibility, study characteristics, and risk of bias

2.2.3 Invite all study sponsors and researchers to submit unpublished data, including unreported outcomes, for possible inclusion in the systematic review

2.2.4 Handsearch selected journals and conference abstracts

2.2.5 Conduct a web search

2.2.6 Search for studies reported in languages other than English if appropriate

\section{STANDARD 2.3}

Screen and select studies

2.3.1 Include or exclude studies based on the protocol's prespecified criteria

2.3.2 Use observational studies in addition to randomized clinical trials to evaluate harms of interventions

2.3.3 Use two or more members of the review team, working independently, to screen and select studies

2.3.4 Train screeners using written documentation; test and retest screeners to improve accuracy and consistency

2.3.5 Use one of two strategies to select studies: (1) read all full-text articles identified in the search or (2) screen titles and abstracts of all articles and then read the full text of articles identified in initial screening

2.3.6 Taking account of the risk of bias, consider using observational studies to address gaps in the evidence from randomized clinical trials on the benefits of interventions

\section{STANDARD 2.4}

Document the search

2.4.1 Provide a line-by-line description of the search strategy, including the date of every search for each database, web browser, etc.

2.4.2 Document the disposition of each report identified including reasons for their exclusion if appropriate

\section{STANDARD 2.5}

Manage data collection 
2.5.1 At a minimum, use two or more researchers, working independently, to extract quantitative and other critical data from each study. For other types of data, one individual could extract the data while the second individual independently checks for accuracy and completeness. Establish a fair procedure for resolving discrepancies-do not simply give final decision-making power to the senior reviewer

2.5.2 Link publications from the same study to avoid including data from the same study more than once

2.5.3 Use standard data extraction forms developed for the specific systematic review

2.5.4 Pilot-test the data extraction forms and process

STANDARD 2.6

Critically appraise each study

2.6.1 Systematically assess the risk of bias, using predefined criteria

2.6.2 Assess the relevance of the study's populations, interventions, and outcome measures

2.6.3 Assess the fidelity of the implementation of interventions

\subsection{STANDARDS FOR SYNTHESIZING THE BODY OF EVIDENCE}

NOTE: The order of the standards does not indicate the sequence in which they are carried out.

\section{STANDARD 3.1}

Use a prespecified method to evaluate the body of evidence

3.1.1 For each outcome, systematically assess the following characteristics of the body of evidence:

- Risk of bias

- Consistency

- Precision

- Directness

- Reporting bias

3.1.2 For bodies of evidence that include observational research, also systematically assess the following characteristics for each outcome:

- Dose-response association

- Plausible confounding that would change the observed effect

- Strength of association

3.1.3 For each outcome specified in the protocol, use consistent language to characterize the level of confidence in the estimates of the effect of an intervention

\section{STANDARD 3.2}

Conduct a qualitative synthesis

3.2.1 Describe the clinical and methodological characteristics of the included studies, including their size, inclusion or exclusion of important subgroups, timeliness, and other relevant factors

3.2.2 Describe the strengths and limitations of individual studies and patterns across studies

3.2.3 Describe, in plain terms, how flaws in the design or execution of the study (or groups of studies) could bias the results, explaining the reasoning behind these judgments

3.2.4 Describe the relationships between the characteristics of the individual studies and their reported findings and patterns across studies

3.2.5 Discuss the relevance of individual studies to the populations, comparisons, cointerventions, settings, and outcomes or measures of interest

\section{STANDARD 3.3}

Decide if, in addition to a qualitative analysis, the systematic review will include a quantitative analysis (meta-analysis)

3.3.1 Explain why a pooled estimate might be useful to decision makers

\section{STANDARD 3.4}

If conducting a meta-analysis, then do the following:

3.4.1 Use expert methodologists to develop, execute, and peer review the meta-analyses

3.4.2 Address the heterogeneity among study effects

3.4.3 Accompany all estimates with measures of statistical uncertainty

3.4.4 Assess the sensitivity of conclusions to changes in the protocol, assumptions, and study selection (sensitivity analysis)

\subsection{STANDARDS FOR REPORTING SYSTEMATIC REVIEWS}

- STANDARD 4.1

Prepare final report using a structured format

4.1.1 Include a report title 
4.1.2 Include an abstract

4.1.3 Include an executive summary

4.1.4 Include a summary written for the lay public

4.1.5 Include an introduction (rationale and objectives)

4.1.6 Include a methods section. Describe the following:

- Research protocol

- Eligibility criteria (criteria for including and excluding studies in the systematic review)

- Analytic framework and key questions

- Databases and other information sources used to identify relevant studies

- Search strategy

- Study selection process

- Data extraction process

- Methods for handling missing information

- Information to be extracted from included studies

- Methods to appraise the quality of individual studies

- Summary measures of effect size (e.g., risk ratio, difference in means)

- $\quad$ Rationale for pooling (or not pooling) results of included studies

- Methods of synthesizing the evidence (qualitative and meta-analysis)

- Additional analyses, if done, indicating which were prespecified

4.1.7 Include a results section. Organize the presentation of results around key questions. Describe the following (repeat for each key question):

- Study selection process

- $\quad$ List of excluded studies and reasons for their exclusion

- Appraisal of individual studies' quality

- Qualitative synthesis

- Meta-analysis of results, if performed (explain rationale for doing one)

- Additional analyses, if done, indicating which were prespecified

- Tables and figures

4.1.8 Include a discussion section. Include the following:

- Summary of the evidence

- Strengths and limitations of the systematic review

- Conclusions for each key questions

- Gaps in evidence

- Future research needs
4.1.9 Include a section describing funding sources and $\mathrm{COI}$

\section{STANDARD 4.2}

Peer review the draft report

4.2.1 Use a third party to manage the peer review process

4.2.2 Provide a public comment period for the report and publicly report on disposition of comments

\section{STANDARD 4.3}

Publish the final report in a manner that ensures free public access

The IOM Committee concluded that systematic reviews should be used to inform health care decisionmakers about what is known and not known about the effectiveness of health interventions (112). Patients expect that their doctors and other health care providers know what type of treatment to recommend. In reality, however, the evidence that informs current health care decisions is often incomplete and may be biased, and there are no standards in place to ensure that systematic reviews of the evidence are objective, transparent, and scientifically valid (11). Better-quality systematic reviews have the potential to improve the decisions made by clinicians, to better inform patient choice, and to provide a more trustworthy basis for decisions by payers and policy makers.

\subsubsection{Methodology}

Evidence assessment for systematic reviews was based on methodological quality assessment criteria recommended for randomized trials, observational studies, and diagnostic studies (417-437). The methodology utilized in the systematic reviews followed the review process derived from evidence-based systematic reviews and meta-analyses of randomized trials and observational studies $(26,42,123,417,434-437)$, Consolidated Standards of Reporting Trials (CONSORT) guidelines for the conduct of randomized trials (121,438-440), Strengthening the Reporting of Observational Studies in Epidemiology (STROBE) (441-443), Cochrane guidelines $(417,444)$, Standards for Reporting of Diagnostic Accuracy (STARD) studies (422), Quality Assessment of Diagnostic Accuracy Studies (QUADAS) (423), Quality Appraisal of Reliability Studies (QAREL) (425), and Chou and Huffman's guidelines (54). 


\subsubsection{Criteria for Considering Studies}

- $\quad$ Types of Studies

RCTs

Nonrandomized observational studies

Diagnostic accuracy studies

Case reports and reviews for adverse effects

- Types of Patients

- Patients of interest were adults aged at least 18 years with chronic spinal pain of at least 3 months duration.

- Patients must have failed previous pharmacotherapy, exercise therapy, etc., prior to starting interventional pain management techniques.

\section{- Types of Interventions}

Diagnostic and therapeutic spinal interventions appropriately performed with proper technique under image guidance (fluoroscopy, computed tomography [CT], or magnetic resonance imaging [MRI]) were included. Ultrasound-guided interventions or interventions without fluoroscopic or CT guidance were excluded.

\section{- Diagnostic Outcome Measures}

For facet joint and sacroiliac joint interventions:

- The primary outcome measure was pain relief concordant with the type of controlled diagnostic blocks performed.

- The secondary outcome measure was the ability to perform previously painful movements without significant pain or complications.

For discography:

- The primary outcome measure was either pain provocation and/or provocation pain relief concordant with the type of discography performed.

For all diagnostic interventions:

- At least 2 of the review authors independently, in an unblinded standardized manner, assessed the outcomes measures. Any disagreements between reviewers were resolved by a third author and consensus.

- $\quad$ Types of Therapeutic Outcome Measures

- The primary outcome parameter was pain relief with short-term defined as up to 6 months and long-term defined as 12 months.

- The secondary outcome measures were functional improvement; change in psychological status; return to work; reduction or elimination of opioid use, other drugs, or other interventions; and complications.

- At least 2 of the review authors independently, in an unblinded standardized manner, as- sessed the outcomes measures. Any disagreements between reviewers were resolved by a third author and consensus.

\subsubsection{Literature Search}

Searches were performed from the following sources without language restrictions:

1. PubMed from 1966

www.ncbi.nlm.nih.gov/sites/entrez?db=pubmed

2. EMBASE from 1980

www.embase.com

3. Cochrane Library www.thecochranelibrary.com/view/0/index.html

4. U.S. National Guideline Clearinghouse (NGC) www.guideline.gov

5. Previous systematic reviews and cross references

6. Clinical Trials

clinicaltrials.gov

The search period included articles from 1966 through 2012.

\subsubsection{Search Strategy}

The search strategy emphasized treating chronic spinal, non-cancer pain of various origins and spinal interventions.

At least 2 of the review authors independently, in an unblinded standardized manner, performed each search. All searches were combined to obtain a unified search strategy. Any disagreements between reviewers were resolved by a third author and consensus.

\subsubsection{Data Collection and Analysis}

The reviews focused on randomized trials, observational studies, diagnostic accuracy studies, and reports of complications. The population of interest was patients suffering from chronic pain of spinal origin. Only epidural interventions, facet joint interventions, sacroiliac joint interventions, discography, vertebroplasty, kyphoplasty, percutaneous disc decompression, spinal cord stimulation, and implantable infusion systems were included. Reports without appropriate diagnosis, nonsystematic reviews, book chapters, and case reports were excluded.

\section{- Selection of Studies}

- In an unblinded, standardized manner, 2 review authors screened the abstracts of all identified studies against the inclusion criteria.

- $\quad$ All articles with possible relevance were then retrieved in full text for a comprehensive as- 
sessment of internal validity, quality, and adherence to inclusion criteria.

\section{- Inclusion and Exclusion Criteria}

The following inclusion and exclusion criteria were established.

1. Are the patients described in sufficient detail to allow you to decide whether they are comparable to those that are seen in interventional pain management clinical practice?

A. Setting - office, hospital, outpatient, inpatient

B. Physician - interventional pain physician, general physician, anesthesiologist, physiatrist, neurologist, rheumatologist, orthopedic surgeon, neurosurgeon, etc.

C. Patient characteristics - duration of pain

D. Previous noninterventional techniques or surgical intervention

2. Is the intervention described well enough to enable you to provide the same for patients in interventional pain management settings?
A. Nature of intervention
B. Frequency of intervention
C. Duration of intervention

3. Were clinically relevant outcomes measured?
A. Proportion of pain relief
B. Disorder/specific disability
C. Functional improvement
D. Allocation of eligible and ineligible patients to return to work
E. Ability to work

\subsubsection{Clinical Relevance}

- The clinical relevance of the included studies was evaluated according to 5 questions recommended by the Cochrane Back Review Group (Table 2) (418). Each question was scored as positive $(+)$ if the clini- cal relevance item was met, negative (-) if the item was not met, and unclear (?) if data were not available to answer the question.

\subsubsection{Study Design Assessment}

RCTs are considered to provide the most internally valid evidence for medical decision-making. In the specialty of interventional pain management, results from clinical trials, both randomized and observational, with substantial impact on patient care, have been ruled ineffective based on flawed methodology of evidence synthesis $(34,50,52,404,444-460)$. Smith and Pell (461) in their famous metaanalysis, proved that the evidence from randomized trials may be inaccurate. They attempted a metaanalysis, reviewing the available randomized trials supporting the use of parachutes to prevent injuries caused by jumping out of an airplane. There were no trials available which had been done, and they concluded that there was insufficient evidence to recommend the use of parachutes. Realizing that very few interventions in medicine work quite as definitively as parachutes, this attempted metaanalysis reminds us that some interventions are of such intuitive value that they do not require RCTs.

The WHO defines a clinical trial as "any research study that prospectively assigns human participants or groups of humans to one or more health-related interventions to evaluate the effects on health outcomes (120)." Very few studies in interventional pain management are RCTs and treatments even in surgery are only half as likely to be based on RCTs as treatments in internal medicine $(34,50,52,445-460,462-465)$. There are multiple studies and opinions for and against randomized trials and observational studies and their importance.

Table 2. Clinical relevance questions.

\begin{tabular}{|c|c|c|c|}
\hline & $\mathbf{P}(+)$ & N (-) & U (unclear) \\
\hline $\begin{array}{l}\text { A) Are the patients described in detail so that one can decide whe } \\
\text { those who are treated in clinical practice? }\end{array}$ & & & \\
\hline $\begin{array}{l}\text { B) Are the interventions and treatment settings described in suffic } \\
\text { clinical practice? }\end{array}$ & & & \\
\hline C) Were clinically relevant outcomes measured and reported? & & & \\
\hline D) Is the size of the effect clinically meaningful? & & & \\
\hline E) Do the likely treatment benefits outweigh the potential harms? & & & \\
\hline
\end{tabular}

Scoring adapted and modified from Staal JB, et al. Injection therapy for subacute and chronic low-back pain. Cochrane Database Syst Rev 2008; 3:CD001824 (418). 
Two components of a randomized trial include randomization and a control group. The randomization and a control group is always a critical decision in designing a clinical trial, as the choice effects the inferences that can be drawn from the trial. However, many ignore the fact that there are various types of control designs in randomized trials. These are placebo control, active control, dose response, placebo + active, placebo + dose response, active + dose response, and finally the best design being placebo + active + dose response. Table 3 shows specific control types based on objectives (466). Most commonly utilized designs in clinical research are placebo control and active control; however, due to various difficulties with designing a true placebo in interventional pain management, active control designs are utilized. An active control design shows existence of effect and also compares therapies in contrast to a placebo control which measures absolute effect size and shows existence of effect. Both have their advantages and disadvantages.

It is essential in interventional pain management or any type of analysis to realize the difference between placebo control and active control. Many researchers have been tending to consider active controls as placebo controls and one of the treatments as placebo. It has been repeatedly shown that local anesthetics and steroids both provide long-term relief $(42,213,214,237,245,265,267,276,314-319-340,345,400-$ 402,467-492). Overall there is no significant evidence that steroids provide long-term relief compared to local anesthetic only except in very specific circumstances.

However, placebo-control is an extremely difficult issue with interventional trials as demonstrated by Gerszten et al (493). Furthermore, there is a great deal of misunderstanding in relation to active-control trials and placebo-control trials. This misunderstanding con- tinues to emerge in interventional pain management, resulting in inappropriate analysis of the evidence. In fact, multiple studies that have considered themselves as placebo-controlled in interventional pain management settings $(2,29,54,454,494-499)$ have utilized local anesthetic injection, in essence producing a facet joint nerve block. As the literature illustrates, a facet joint nerve block can provide on average 13 to 16 weeks of prolonged relief $(335,337,338)$. This may have been problematic in interpretation in many placebo controlled interventional trials (395-397,500-503). Consequently, these studies could be construed as activecontrol trials even though sham treatment was utilized. Similarly, multiple studies in the evaluation of epidural treatment have utilized local anesthetic and called them placebo studies. Proper terminology may be that these are sham-controlled but not placebo-controlled. It is not always feasible to perform placebo-controlled studies in an interventional setting, and the absence of these studies has led to some third party payers denying payment for effective therapies.

It has been widely reported by Cochrane reviewers and others that placebo effect studies are susceptible to response bias and to other types of biases. Hróbjartsson et al (504) reviewed the pervasive and complex connection between the placebo effect and bias. Ever since the concept of the placebo was brought to the attention of the medical community by Beecher (505) in his classic 1955 JAMA article, "The Powerful Placebo," in which he presented a review of assorted placebo-control trials, and argued that the substantial improvement in the condition of patients receiving placebo was caused by the placebo intervention. Nevertheless, Beecher's analysis committed the very fallacy that underlies the need for controlled trials. The observed response to placebo in randomized trials does not itself provide any reli-

Table 3. Description of specific control types based on objectives.

\begin{tabular}{||l|c|c|c|c|c|c|c||}
\hline \multirow{2}{*}{ Trial Objective } & \multicolumn{9}{|c|}{ Type of Control } \\
\cline { 2 - 9 } & $\begin{array}{c}\text { Placebo } \\
\text { Control }\end{array}$ & $\begin{array}{c}\text { Active } \\
\text { Control }\end{array}$ & $\begin{array}{c}\text { Dose } \\
\text { Response } \\
(\mathbf{D} / \mathbf{R})\end{array}$ & $\begin{array}{c}\text { Placebo } \\
+ \\
\text { Active }\end{array}$ & $\begin{array}{c}\text { Placebo } \\
+ \\
\text { D/R }\end{array}$ & $\begin{array}{c}\text { Active } \\
+ \\
\text { D/R }\end{array}$ & $\begin{array}{c}\text { Placebo }+ \\
\text { Active }+ \\
\text { D/R }\end{array}$ \\
\hline Measure Absolute effect size & $\mathrm{Y}$ & $\mathrm{N}$ & $\mathrm{N}$ & $\mathrm{Y}$ & $\mathrm{Y}$ & $\mathrm{N}$ & $\mathrm{Y}$ \\
\hline Show existence of effect & $\mathrm{Y}$ & $\mathrm{Y}$ & $\mathrm{Y}$ & $\mathrm{Y}$ & $\mathrm{Y}$ & $\mathrm{Y}$ & $\mathrm{Y}$ \\
\hline Show dose-response relationship & $\mathrm{N}$ & $\mathrm{N}$ & $\mathrm{Y}$ & $\mathrm{N}$ & $\mathrm{Y}$ & $\mathrm{Y}$ & $\mathrm{Y}$ \\
\hline Compare therapies & $\mathrm{N}$ & $\mathrm{Y}$ & $\mathrm{N}$ & $\mathrm{Y}$ & $\mathrm{N}$ & $\mathrm{P}$ & $\mathrm{Y}$ \\
\hline
\end{tabular}

Source: International Conference on Harmonisation of Technical Requirements for Registration of Pharmaceuticals for Human Use. ICH Harmonised Tripartite Guideline. Choice of Control Group and Related Issues in Clinical Trials E10. July 20, 2000 (466). 
able, unbiased, evidence of a placebo effect -an outcome caused by receiving a sham treatment disguised to be indistinguishable from an active medical intervention. Further, unbiased assessment of the placebo effect requires comparison of placebo interventions with a suitable control group in order to distinguish an effect of the placebo intervention from confounding factors, for example the natural history of the condition under investigation or regression to the mean (506). Even though Beecher's approach were clearly recognized as flawed in the late 1990's (507), by that time the notion of 'powerful placebo' became deeply rooted. Meanwhile methodologists haven't started anchoring to every study results to the natural history of the condition under investigation or regression to the mean. However, Krogsbøll et al in (508) reference to spontaneous improvement in randomized clinical trials and metaanalysis of 3-armed trials comparing no treatment, placebo, and active intervention, dispelled these myths. They showed that the conditions that had most pronounced spontaneous improvement were nausea $45 \%$, smoking $40 \%$, depression $35 \%$, phobia $34 \%$, and acute pain $25 \%$. They also showed that overall, across all conditions and interventions there was a statistically significant change from baseline in all 3 arms. However, for chronic pain no treatment contributed to very small improvement and placebo response was also less than $30 \%$, whereas active treatment showed effect of $60 \%$. Assessment of standardized mean difference for changes from baseline group by acute or chronic conditions showed no change in the no treatment group. Consequently, authors concluded that spontaneous improvement and effect of placebo contributed importantly to the observed treatment effect in actively treated patients, but the relative importance of these factors differed according to clinical condition and intervention. Further, in 2001, in sharp contrast, the power of placebo was challenged by a systematic review published in the New England Journal of Medicine (509). This review identified 114 randomized clinical trials including placebo and no treatment groups, and reported no evidence of overall effects of placebo for objective and binary outcomes and a small, and doubtfully clinically relevant, effect for continuous subjective outcomes, such as pain. These findings are clearly incompatible with Beecher's classic position and present methodologists view of spontaneous improvement of the disorder or disease. While some academic commentators either pointed out that worthwhile effects could still exist in some settings (510), or saw the review as a necessary scientific correc- tion to set the bar differently for claims concerning placebo (511), some media commentators interpreted the result as demonstrating the placebo effect to be a myth (512). Even though review which was updated in 2004 showed similar findings (513), the latest update from 2010 reported more multifaceted results (514). The recent systematic review showed that large analgesic effects of placebo interventions were found in several well conducted trials and a considerable variation in effect could in part be explained by differences in trial design, for example, effect of placebo was larger when the intervention was a device as compared with pill placebo. Overall popular fascination with the placebo effect, specifically methodologists who do not like any type of interventions in medicine, fueled fascination with the placebo effect with unrealistic assessments of its therapeutic effects to rule out any treatment effects. On the same token, some have suggested the therapeutic potential of placebos (515). However, all the metaanalysis $(511,513,514)$ involving progressively larger number of studies and subjects, performed for Cochrane review, challenges the belief that in general that the placebo is powerful. Consequently, estimating the size of the effect of placebo is not only subject to considerable uncertainty, but seems to be almost impossible. Hróbjartsson et al (504) in their methodological analysis and discussion of placebo effect studies and their susceptibility to response bias and to other types of biases, showed that the difference between placebo and no-treatment remains an approximately and fairly crude reflection of the true effect of placebo intervention. They showed that a main problem is response bias in trials with outcomes that are based on patient's reports. Other biases involve differential co-intervention and patient drop-outs, publication bias, and outcome reporting bias, however, they have ignored the bias of the methodologists and improper analysis, and lack of consideration of injection of an inactive solution into active structure. Consequently, extrapolation of results to clinical settings are challenging because of lack of clear identification of the causal factors in many clinical trials, and the non-clinical settings and short duration of most laboratory experiments. They (504) concluded that creative experimental efforts are needed to assess rigorously the clinical significance of placebo interventions and investigate the component elements that may contribute to therapeutic benefit. In fact, nonanalgesic solutions (e.g., saline) injected into painful structures have been reported to result in significant activity or even pain relief not only for spinal pain, but also for 
other chronic pain conditions (516-526). The placebo and nocebo effects, and decisions to consider all local anesthetic injections as placebo, are due to a lack of understanding about the scientific basis for placebo and nocebo $(50,518,519,527-541)$. Further, the hazards of evidence-based medicine have been well described in the literature. Thus, it is essential to understand not only the study design but placebo and nocebo influences on the outcomes.

\subsubsection{Methodological Quality or Validity Assessment}

The methodological quality assessment was performed by 2 review authors who independently assessed, in an unblinded standardized manner, the internal validity of all the studies. The methodological quality assessment was performed in such a manner as to avoid any discrepancies, which when identified were evaluated by a third reviewer and settled by consensus. Authors with a perceived $\mathrm{COI}$ for any manuscript were recused from reviewing the manuscript.

For adverse effects, confounding factors, etc., it was not possible to use quality assessment criteria. Thus, these were considered based on the interpretation of the reports published and critical analysis of the literature.

The quality of each individual article used in this analysis was assessed using Cochrane review criteria (Table 4) (417) for randomized trials, the NewcastleOttawa Scale for observational studies (Tables 5 and 6) (419), and the QAREL checklist for diagnostic accuracy studies (Table 7) (425). For nonrandomized observational studies, the patient population was required to have at least 50 total or at least 25 in each group if there were comparison groups. Even though none of these instruments or criteria has been systematically assessed, the advantages and disadvantages of each system were debated.

Each study was evaluated by at least 2 authors for stated criteria and any disagreements discussed with a third reviewer.

The QAREL checklist (425) has been validated and also utilized in multiple systematic reviews (421-426). Each study in the final sample of eligible manuscripts was assessed using a 12-item appraisal checklist designed to assess the quality and applicability of studies. The face validity of these checklists was established by consultation with methodology experts (425) and comparison with quality appraisal checklists used in other systematic reviews examining diagnostic reliability
(420,427-434). This checklist was also developed in accordance with the Standards for the Reporting Studies of Diagnostic Accuracy Studies (STARD) (422) and the QUADAS (423) appraisal tool. Studies were not given an overall numeric quality score; instead, each item was considered separately and graded as "yes," "no," "unclear," or "not applicable."

All studies were required to meet a minimum of $50 \%$ of applicable criteria. Studies scoring less were also described and provided with an opinion and a critical analysis.

\subsubsection{Measurement of Treatment Effect in Data Synthesis (Meta-Analysis)}

Data were summarized using meta-analysis when at least 5 studies per type of disorder were available meeting the inclusion criteria.

\subsubsection{Outcome Measures}

Conclusions of both qualitative and quantitative outcome measures were evaluated. Qualitative (the direction of a treatment effect) and quantitative (the magnitude of a treatment effect) conclusions were evaluated. Random-effects meta-analysis to pool data was also used (542-544).

The minimum amount of change in pain score to be clinically meaningful has been described as a 2-point change on a scale of 0 to 10 (or 20 percentage points), based on findings in trials studying general chronic pain (545), chronic musculoskeletal pain (546), and chronic low back pain $(26,434,436,547,548)$. However, recent studies evaluating interventional techniques have used $>50 \%$ pain relief as the cutoff threshold for clinically meaningful improvement in pain relief or functional status (276,304-306,311,314-321,323-330,333$340,345,549)$. Consequently, for analysis in these systematic reviews, we utilized clinically meaningful pain relief of at least a 3-point change on an 11-point scale of 0 to 10 , or $50 \%$ pain relief from the baseline, and/or a functional status improvement of $40 \%$ or more as clinically significant.

Outcomes may be assessed between the groups or in the same group from baseline to post treatment, however, some methodologists tend to focus only on between the groups. This essentially provides lack of improvement or lack of difference between the groups in an active control trial, non-inferiority, or equivalence trial. Thus, it is essential that outcomes be monitored pretreatment and posttreatment rather than between the groups or utilizing both methodologies. Conse- 
Table 4. Randomized controlled trials quality rating system.

\begin{tabular}{|c|c|c|c|}
\hline $\bar{A}$ & $\begin{array}{l}\text { 1. Was the method } \\
\text { of randomization } \\
\text { adequate? }\end{array}$ & $\begin{array}{l}\text { A random (unpredictable) assignment sequence. Examples of adequate methods are coin toss (for studies with } 2 \\
\text { groups), rolling a die (for studies with } 2 \text { or more groups), drawing of balls of different colors, drawing of ballots } \\
\text { with the study group labels from a dark bag, computer-generated random sequence, pre-ordered sealed envelopes, } \\
\text { sequentially-ordered vials, telephone call to a central office, and pre-ordered list of treatment assignments. Examples } \\
\text { of inadequate methods are: alternation, birth date, social insurance/ security number, date in which they are invited to } \\
\text { participate in the study, and hospital registration number. }\end{array}$ & $\begin{array}{l}\text { Yes/No/ } \\
\text { Unsure }\end{array}$ \\
\hline B & $\begin{array}{l}\text { 2. Was the treatment } \\
\text { allocation concealed? }\end{array}$ & $\begin{array}{l}\text { Assignment generated by an independent person not responsible for determining the eligibility of the } \\
\text { patients. This person has no information about the persons included in the trial and has no influence on the } \\
\text { assignment sequence or on the decision about eligibility of the patient. }\end{array}$ & $\begin{array}{l}\text { Yes/No/ } \\
\text { Unsure }\end{array}$ \\
\hline \multirow[t]{4}{*}{$\mathrm{C}$} & \multicolumn{3}{|c|}{ Was knowledge of the allocated interventions adequately prevented during the study? } \\
\hline & $\begin{array}{l}\text { 3. Was the patient } \\
\text { blinded to the } \\
\text { intervention? }\end{array}$ & $\begin{array}{l}\text { This item should be scored "yes" if the index and control groups are indistinguishable for the patients or if } \\
\text { the success of blinding was tested among the patients and it was successful. }\end{array}$ & $\begin{array}{l}\text { Yes/No/ } \\
\text { Unsure }\end{array}$ \\
\hline & $\begin{array}{l}\text { 4. Was the care } \\
\text { provider blinded to the } \\
\text { intervention? }\end{array}$ & $\begin{array}{l}\text { This item should be scored "yes" if the index and control groups are indistinguishable for the care providers } \\
\text { or if the success of blinding was tested among the care providers and it was successful. }\end{array}$ & $\begin{array}{l}\text { Yes/No/ } \\
\text { Unsure }\end{array}$ \\
\hline & $\begin{array}{l}\text { 5. Was the outcome } \\
\text { assessor blinded to the } \\
\text { intervention? }\end{array}$ & $\begin{array}{l}\text { Adequacy of blinding should be assessed for the primary outcomes. This item should be scored "yes" if the success } \\
\text { of blinding was tested among the outcome assessors and it was successful or: } \\
\text {-for patient-reported outcomes in which the patient is the outcome assessor (e.g., pain, disability): the blinding } \\
\text { procedure is adequate for outcome assessors if participant blinding is scored "yes" } \\
\text {-for outcome criteria assessed during scheduled visit and that supposes a contact between participants and } \\
\text { outcome assessors (e.g., clinical examination): the blinding procedure is adequate if patients are blinded, and the } \\
\text { treatment or adverse effects of the treatment cannot be noticed during clinical examination } \\
\text {-for outcome criteria that do not suppose a contact with participants (e.g., radiography, magnetic resonance } \\
\text { imaging): the blinding procedure is adequate if the treatment or adverse effects of the treatment cannot be noticed } \\
\text { when assessing the main outcome } \\
\text {-for outcome criteria that are clinical or therapeutic events that will be determined by the interaction between } \\
\text { patients and care providers (e.g., co-interventions, hospitalization length, treatment failure), in which the care } \\
\text { provider is the outcome assessor: the blinding procedure is adequate for outcome assessors if item "4" (caregivers) } \\
\text { is scored "yes" } \\
\text {-for outcome criteria that are assessed from data of the medical forms: the blinding procedure is adequate if the } \\
\text { treatment or adverse effects of the treatment cannot be noticed on the extracted data. }\end{array}$ & $\begin{array}{l}\text { Yes/No/ } \\
\text { Unsure }\end{array}$ \\
\hline \multirow[t]{3}{*}{$\mathrm{D}$} & \multicolumn{3}{|c|}{ Were incomplete outcome data adequately addressed? } \\
\hline & $\begin{array}{l}\text { 6. Was the drop-out } \\
\text { rate described and } \\
\text { acceptable? }\end{array}$ & $\begin{array}{l}\text { The number of participants who were included in the study but did not complete the observation period or } \\
\text { were not included in the analysis must be described and reasons given. If the percentage of withdrawals and } \\
\text { drop-outs does not exceed } 20 \% \text { for short-term follow-up and } 30 \% \text { for long-term follow-up and does not lead to } \\
\text { substantial bias a "yes" is scored. (N.B. these percentages are arbitrary, not supported by literature). }\end{array}$ & $\begin{array}{l}\text { Yes/No/ } \\
\text { Unsure }\end{array}$ \\
\hline & $\begin{array}{l}\text { 7. Were all randomized } \\
\text { participants analyzed in } \\
\text { the group to which they } \\
\text { were allocated? }\end{array}$ & $\begin{array}{l}\text { All randomized patients are reported/analyzed in the group they were allocated to by randomization for the } \\
\text { most important moments of effect measurement (minus missing values) irrespective of non-compliance and } \\
\text { co-interventions. }\end{array}$ & $\begin{array}{l}\text { Yes/No/ } \\
\text { Unsure }\end{array}$ \\
\hline $\mathrm{E}$ & $\begin{array}{l}\text { 8. Are reports of the } \\
\text { study free of suggestion } \\
\text { of selective outcome } \\
\text { reporting? }\end{array}$ & $\begin{array}{l}\text { In order to receive a "yes," the review author determines if all the results from all pre-specified outcomes } \\
\text { have been adequately reported in the published report of the trial. This information is either obtained by } \\
\text { comparing the protocol and the report, or in the absence of the protocol, assessing that the published report } \\
\text { includes enough information to make this judgment. }\end{array}$ & $\begin{array}{l}\text { Yes/No/ } \\
\text { Unsure }\end{array}$ \\
\hline \multirow[t]{5}{*}{$\mathrm{F}$} & \multicolumn{3}{|c|}{ Other sources of potential bias: } \\
\hline & $\begin{array}{l}\text { 9. Were the groups similar } \\
\text { at baseline regarding } \\
\text { the most important } \\
\text { prognostic indicators? }\end{array}$ & $\begin{array}{l}\text { In order to receive a "yes," groups have to be similar at baseline regarding demographic factors, duration } \\
\text { and severity of complaints, percentage of patients with neurological symptoms, and value of main outcome } \\
\text { measure(s). }\end{array}$ & $\begin{array}{l}\text { Yes/No/ } \\
\text { Unsure }\end{array}$ \\
\hline & $\begin{array}{l}\text { 10. Were co-interventions } \\
\text { avoided or similar? }\end{array}$ & $\begin{array}{l}\text { This item should be scored "yes" if there were no co-interventions or they were similar between the index } \\
\text { and control groups. }\end{array}$ & $\begin{array}{l}\text { Yes/No/ } \\
\text { Unsure }\end{array}$ \\
\hline & $\begin{array}{l}\text { 11. Was the compliance } \\
\text { acceptable in all groups? }\end{array}$ & $\begin{array}{l}\text { The reviewer determines if the compliance with the interventions is acceptable, based on the reported } \\
\text { intensity, duration, number and frequency of sessions for both the index intervention and control } \\
\text { intervention(s). For example, physiotherapy treatment is usually administered over several sessions; therefore } \\
\text { it is necessary to assess how many sessions each patient attended. For single-session interventions (e.g., } \\
\text { surgery), this item is irrelevant. }\end{array}$ & $\begin{array}{l}\text { Yes/No/ } \\
\text { Unsure }\end{array}$ \\
\hline & $\begin{array}{l}\text { 12. Was the timing of } \\
\text { the outcome assessment } \\
\text { similar in all groups? }\end{array}$ & $\begin{array}{l}\text { Timing of outcome assessment should be identical for all intervention groups and for all important outcome } \\
\text { assessments. }\end{array}$ & $\begin{array}{l}\text { Yes/No/ } \\
\text { Unsure }\end{array}$ \\
\hline
\end{tabular}

Adapted and modified from Furlan AD, et al; Editorial Board, Cochrane Back Review Group. 2009 updated method guidelines for systematic reviews in the Cochrane Back Review Group. Spine (Phila Pa 1976) 2009; 34:1929-1941 (417). 
Table 5. Newcastle-Ottawa quality assessment scale: Case control studies.

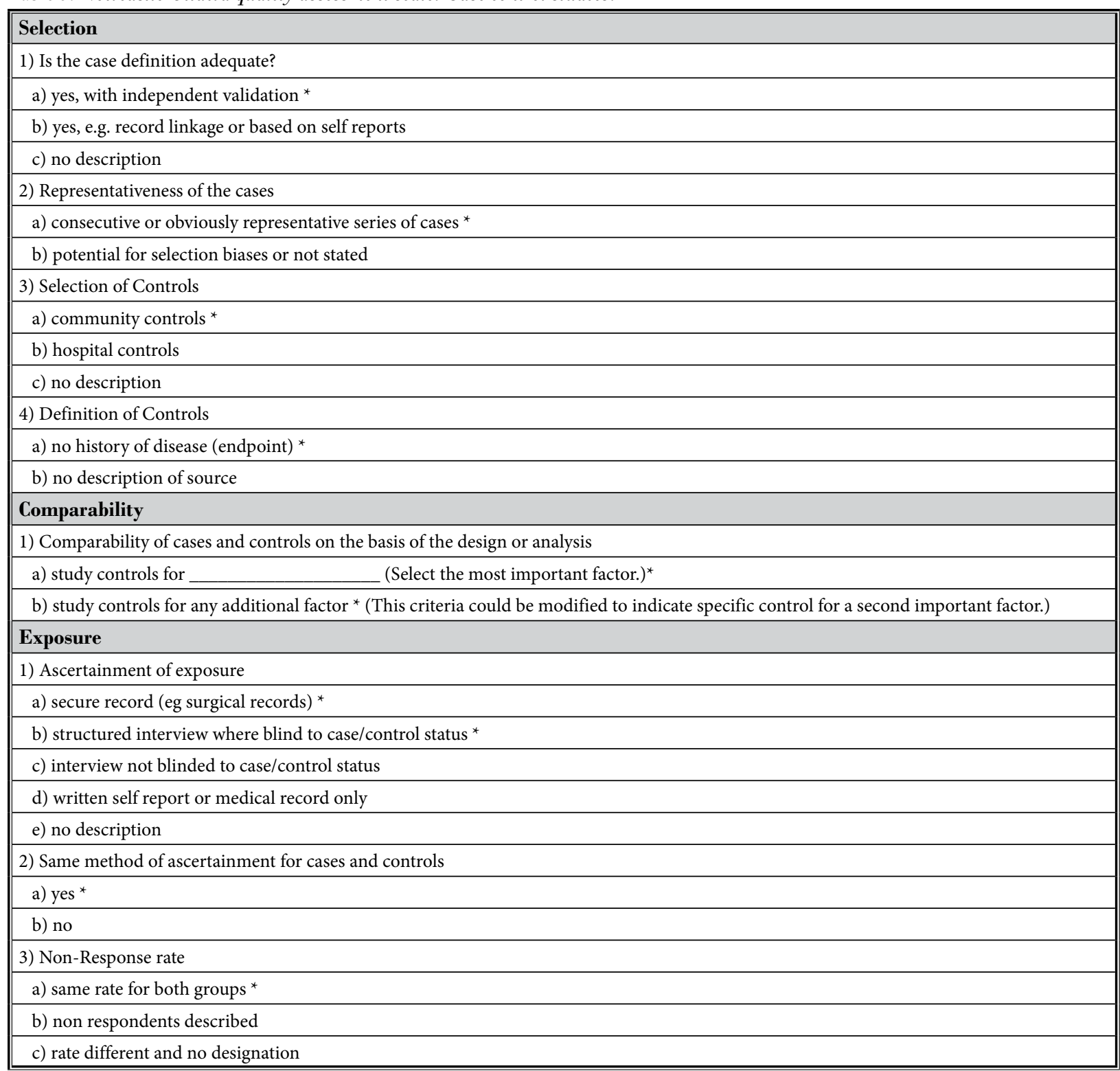

Note: A study can be awarded a maximum of one star for each numbered item within the Selection and Exposure categories. A maximum of two stars can be given for Comparability.

Wells GA, et al. The Newcastle-Ottawa Scale (NOS) for assessing the quality of nonrandomized studies in meta-analysis. www.ohri.ca/programs/ clinical_epidemiology/oxford.asp (419).

quently, in all the systematic reviews and the evidence assessment for interventional pain management, the outcomes have been assessed based on the design between the groups and in the same group pre and post treatment.

\subsubsection{Outcome of the Studies}

Randomized trials were judged to be positive if the intervention was clinically relevant and effective, either with a placebo control or an active control. This indicates that the difference in effect for the primary 
Table 6. Newcastle-Ottawa quality assessment scale for cohort studies.

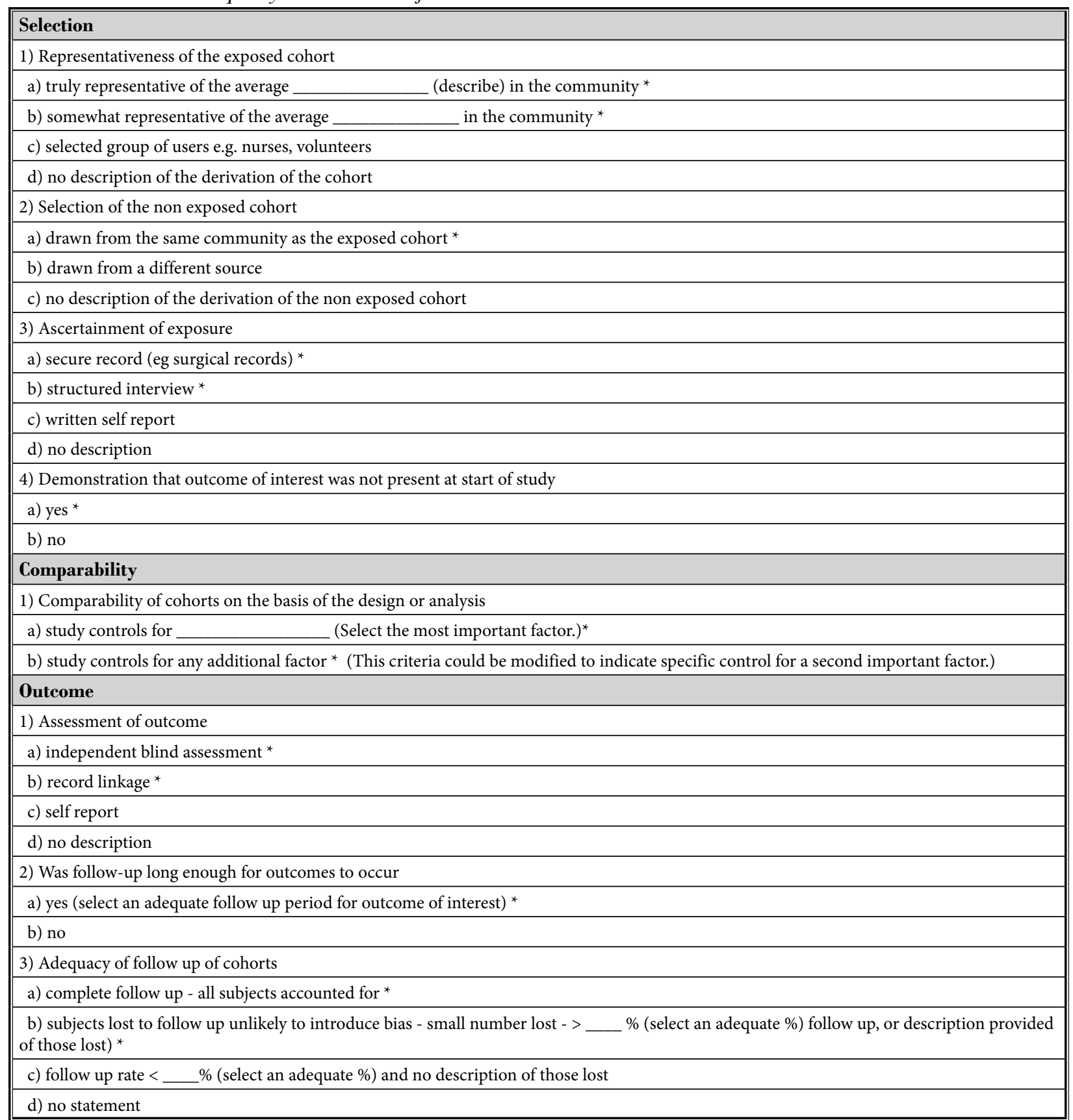

Note: A study can be awarded a maximum of one star for each numbered item within the Selection and Outcome categories. A maximum of two stars can be given for Comparability.

Wells GA, et al. The Newcastle-Ottawa Scale (NOS) for assessing the quality of nonrandomized studies in meta-analysis. www.ohri.ca/programs/ clinical_epidemiology/oxford.asp (419).

outcome measure is statistically significant on the conventional $5 \%$ level. In a negative study, no significant difference between the treatment groups or no improvement from baseline is identified.
Observational studies were judged to be positive if the intervention was effective, with outcomes reported at one month, 3 months, 6 months, and one year.

The outcomes were judged as improvement in at 
Table 7. Quality Appraisal of Diagnostic Reliability (QAREL) checklist.

\begin{tabular}{|c|c|c|c|c|}
\hline Item & Yes & No & Unclear & N/A \\
\hline $\begin{array}{l}\text { 1. Was the test evaluated in a spectrum of subjects representative of patients who would normally } \\
\text { receive the test in clinical practice? }\end{array}$ & & & & \\
\hline $\begin{array}{l}\text { 2. Was the test performed by examiners representative of those who would normally perform the test } \\
\text { in practice? }\end{array}$ & & & & \\
\hline 3. Were raters blinded to the reference standard for the target disorder being evaluated? & & & & \\
\hline 4. Were raters blinded to the findings of other raters during the study? & & & & \\
\hline 5. Were raters blinded to their own prior outcomes of the test under evaluation? & & & & \\
\hline 6. Were raters blinded to clinical information that may have influenced the test outcome? & & & & \\
\hline 7. Were raters blinded to additional cues, not intended to form part of the diagnostic test procedure? & & & & \\
\hline 8. Was the order in which raters examined subjects varied? & & & & \\
\hline 9. Were appropriate statistical measures of agreement used? & & & & \\
\hline 10. Was the application and interpretation of the test appropriate? & & & & \\
\hline $\begin{array}{l}\text { 11. Was the time interval between measurements suitable in relation to the stability of the variable } \\
\text { being measured? }\end{array}$ & & & & \\
\hline 12. If there were dropouts from the study, was this less than $20 \%$ of the sample. & & & & \\
\hline TOTAL & & & & \\
\hline
\end{tabular}

Lucas N, et al. The development of a quality appraisal tool for studies of diagnostic reliability (QAREL). J Clin Epidemiol 2010; 63:854-861 (425).

Table 8. Method for grading the overall strength of the evidence for an intervention.

\begin{tabular}{|l|l||}
\hline \multicolumn{1}{|c|}{ Grade } & \multicolumn{1}{c|}{ Definition } \\
\hline Good & $\begin{array}{l}\text { Evidence includes consistent results from well-designed, well-conducted studies in representative populations that directly } \\
\text { assess effects on health outcomes (at least 2 consistent, higher-quality RCTs or studies of diagnostic test accuracy). }\end{array}$ \\
\hline Fair & $\begin{array}{l}\text { Evidence is sufficient to determine effects on health outcomes, but the strength of the evidence is limited by the number, } \\
\text { quality, size, or consistency of included studies; generalizability to routine practice; or indirect nature of the evidence on health } \\
\text { outcomes (at least one higher-quality trial or study of diagnostic test accuracy of sufficient sample size; 2 or more higher- } \\
\text { quality trials or studies of diagnostic test accuracy with some inconsistency; at least 2 consistent, lower-quality trials or studies } \\
\text { of diagnostic test accuracy, or multiple consistent observational studies with no significant methodological flaws). }\end{array}$ \\
\hline Limited or poor & $\begin{array}{l}\text { Evidence is insufficient to assess effects on health outcomes because of limited number or power of studies, large and } \\
\text { unexplained inconsistency between higher-quality trials, important flaws in trial design or conduct, gaps in the chain of } \\
\text { evidence, or lack of information on important health outcomes. }\end{array}$ \\
\hline \hline
\end{tabular}

Adapted from methods developed by U.S. Preventive Services Task Force $(54,550)$.

least $40 \%$ of patients at distinct reference points with positive or negative results reported at one month, 3 months, 6 months, and one year.

Outcomes included the prevalence of pain and false-positive rate. Based on the above parameters, the reliability of the data derived from each study was assessed.

The advantages and disadvantages of various methodologies available are too extensive to be described in this manuscript. These have been described in various other manuscripts in the past $(28-31,69-72)$.

\subsubsection{Analysis of Evidence}

Evidence analysis was performed based on United States Preventive Task Force (USPSTF) criteria as illustrated in Table 8 , which has been utilized by multiple authors (550).

The analysis was conducted using 3 levels of evidence ranging from good, fair, and limited or poor.

\subsubsection{Grading Recommendations}

As recommended by the IOM, for each recommendation, information was provided with an explanation 
of the reasoning underlying the recommendation, including a clear description of potential benefits and harms; a summary of relevant available evidence, description of the quality, quantity, and consistency of the aggregate available evidence; an explanation of the part played by values, opinion, theory, and clinical experience in deriving the recommendations; a rating of the level of confidence, a rating of the strength of recommendation, and a description and explanation of any differences of opinion regarding the recommendation.

In grading recommendations, the grading of recommendations from USPSTF was utilized (Table 8).

\subsubsection{External Review}

All the systematic reviews underwent peer review prior to publication. The guidelines were posted for comment from the ASIPP membership and others on the website and also widely advertised in the ASIPP newsletter for comments.

\subsubsection{Updating}

Updating of clinical practice guidelines is crucial. Clinical practice guidelines have become increasingly popular over the last 2 decades, with evolving methodologies to develop guidelines. In the preparation of these guidelines, we have not only given significant attention to the selection and appraisal of the available literature through systematic reviews, through the utilization of appropriate grading systems, which continue to evolve, and through assessment of the strength of recommendations; since the first guideline, ASIPP has focused on updating them. Each guideline has included a timeline for updating. These guidelines become effective January 1, 2013, and expire December 31, 2015. Meanwhile, the updating process will be initiated and completed. In a recent international survey, AlonsoCoello et al (69) found that, among the institutions responding, $92 \%$ reported updating their guidelines, with $86 \%$ reporting a formal procedure for doing so. However, only $53 \%$ had a formal process for deciding when a guideline becomes out of date. Interventional pain management, as an evolving specialty, continues to progress with publications. Even though we have decided on updating in 3 years, we will once again assess the evidence within one year and re-evaluate the timeline.

\section{Acknowledgments}

The authors wish to thank Vidyasagar Pampati, MSc, for statistical assistance; Sekar Edem for assistance in the search of the literature; Alvaro F. Gómez, MA, and Laurie Swick, BS for manuscript review; and Tonie M. Hatton and Diane E. Neihoff, transcriptionists, for their assistance in preparation of this manuscript. We would like to thank the editorial board of Pain Physician for review and criticism in improving the manuscript.

\section{Author Affiliations}

Dr. Manchikanti is Medical Director of the Pain Management Center of Paducah, Paducah, KY, and Clinical Professor, Anesthesiology and Perioperative Medicine, University of Louisville, Louisville, KY.

Dr. Falco is Medical Director of Mid Atlantic Spine \& Pain Physicians, Newark, DE; Director, Pain Medicine Fellowship Program, Temple University Hospital, Philadelphia, PA; and Associate Professor, Department of PM\&R, Temple University Medical School, Philadelphia, PA.

Dr. Singh is Medical Director, Spine Pain Diagnostics Associates, Niagara, WI.

Dr. Benyamin is the Medical Director, Millennium Pain Center, Bloomington, IL, and Clinical Assistant

Professor of Surgery, College of Medicine, University of Illinois, Urbana-Champaign, IL.

Dr. Racz is Professor and Chairman Emeritus, Texas Tech University Health Sciences Center, Lubbock, TX.

Dr. Helm is Medical Director, The Helm Center for Pain Management, Laguna Hills, CA.

Dr. Caraway, St. Mary's Pain Relief Center, Huntington, WV.

Dr. Calodney is a Staff Physician and Director and Research Coordinator Implantable Therapies at NeuroCare Network, Tyler, TX.

Dr. Snook is Medical Director of Metropolitan Pain Management Consultants, Inc., Sacramento, CA

Dr. Smith is Professor and Academic Director of Pain Management for Albany Medical College Department of Anesthesiology, Albany, NY.

Dr. Gupta is a Consultant in Pain Medicine and Anaesthesia, Bradford Teaching Hospital NHS Foundation Trust, Bradford Royal Infirmary, Bradford, United Kingdom.

Dr. Ward is a Consultant in Pain Medicine, Brighton and Sussex University Hospitals NHS Trust, Council Member of the British Pain Society, a Fellow of the Faculty of Pain Medicine of the Royal College of Anaesthetists and Secretary of the British Pain Society Interventional Pain Medicine Special Interest Group, United Kingdom.

Dr. Grider is Medical Director, UK HealthCare Pain 
Services, Division Chief, Pain and Regional Anesthesia, and Associate Professor, Department of Anesthesiology, University of Kentucky, Lexington, KY.

Dr. Hirsch is Vice Chief of Interventional Care, Chief of Minimally Invasive Spine Surgery, Service Line Chief of Interventional Radiology, Director of Endovascular Neurosurgery and Neuroendovascular Program, Massachusetts General Hospital; and Associate Professor, Harvard Medical School, Boston, MA.

\section{Disclaimer}

There was no external funding in preparation of this manuscript.

The authors are solely responsible for the content of this article. No statement on this article should be construed as an official position of ASIPP. The guidelines do not represent "standard of care."

\section{Conflict of Interest:}

Dr. Falco is a consultant for St. Jude Medical Inc. and Joimax Inc.

Dr. Benyamin is a consultant with Bioness and Nevro; serves on the advisory boards of Vertos Medical and Nuvo Pharma; teaches/lectures for Vertos Medical, Boston Scientific, Neurotherm, and Bioness; and receives research/grants from Alfred Mann Foundation, Teknon Foundation, Spinal Restoration, Inc., Bioness, Boston Scientific, Vertos Medical, Medtronic, Kimberly Clarke, Epimed, BioDelivery Sciences International, Inc., Theravance, Mundipharma Research, Cephalon/Teva, AstraZeneca, and Purdue Pharma, LP.

Dr. Helm is a clinical investigator with Epimed and receives research support from Cephalon/Teva, AstraZeneca, and Purdue Pharma, LP. He has attended an advisory group meeting for Activas.

Dr. Caraway is a consultant for Medtronic, Inc., Spinal Modulation, Inc., and Vertos, Inc.

Dr. Grider is an educational trainer for Vertos Medical.

\section{References}

1. Gagliardi AR, Brouwers MC. Integrating guideline development and implementation: Analysis of guideline development manual instructions for generating implementation advice. Implement Sci 2012; 7:67.

2. Manchikanti L, Benyamin RM, Fal- 7 . co FJE, Caraway DL, Datta S, Hirsch JA. Guidelines warfare over interventional techniques: Is there a lack of discourse or straw man? Pain Physician 2012; 15:E1E26.

3. Manchikanti L, Caraway DL, Parr AT, Fellows B, Hirsch JA. Patient Protection and Affordable Care Act of 2010: Reforming health care reform for the new decade. Pain Physician 2011; 14:E35-E67.

4. Manchikanti L, Hirsch JA. Obamacare 2012: Prognosis unclear for interventional pain management. Pain Physician 2012; 15:E629-E640.

5. Manchikanti L, Caraway DL, Falco FJE, Benyamin RM, Hansen $\mathrm{H}$, Hirsch JA. CMS proposal for interventional pain management by nurse anesthetists: Evidence by proclamation with poor prognosis. Pain Physician 2012; 15:E641-E664.

6. Manchikanti L, Falco FJ, Benyamin RM, Helm S 2nd, Parr AT, Hirsch JA. The impact of comparative effectiveness re- search on interventional pain management: Evolution from Medicare Modernization Act to Patient Protection and Affordable Care Act and the Patient-Centered Outcomes Research Institute. Pain Physician 2011; 14:E249-E282.

7. Manchikanti L, Helm II S, Hirsch JA. The evolution of the Patient-Centered Outcome Research Institute. J Neurointervent Surg 2012; 4:157-162.

8. Manchikanti L, Falco FJE, Singh V, Benyamin RM, Hirsch JA. The Independent Payment Advisory Board. Pain Physician 2011; 14:E313-E342.

9. Manchikanti L, Hirsch JA. The Independent Payment Advisory Board: Impact on neurointerventionalists. J Neurointerv Surg 2011; Published Online First: October 11, 2011.

10. Bredesen P. Fresh Medicine: How to Fix Reform and Build a Sustainable Health Care System. First Edition. Atlantic Monthly Press, New York, 2010.

11. U.S. Department of Health and Human Services Agency for Healthcare Research and Quality (AHRQ).

www.ahrq.gov

12. Loblaw DA, Prestrud AA, Somerfield MR, Oliver TK, Brouwers MC, Nam RK, Lyman GH, Basch E. American Society of Clinical Oncology Clinical Practice Guidelines: Formal systematic reviewbased consensus methodology. J Clin Oncol 2012; 30:3136-3140.

13. Tricoci P, Allen JM, Kramer JM, Califf RM, Smith SC Jr. Scientific evidence underlying the ACC/AHA clinical practice guidelines. JAMA 2009; 301:831-841. Erratum in: JAMA 2009; 301:1544.

14. Greene JA, Jones DS, Podolsky SH. Therapeutic evolution and the challenge of rational medicine. N Engl J Med 2012; 367:1077-1082.

15. Butterworth JF 4th, Rathmell JP. Standard care, standards for care, or standard of care? Anesthesiology 2010; 112:277-278.

16. Graham R, Mancher M, Wolman DM, Greenfield S, Steinberg E (eds); Committee on Standards for Developing Trustworthy Clinical Practice Guidelines; Institute of Medicine. Clinical Practice Guidelines We Can Trust. The National Academies Press, Washington, DC, 2011.

17. Field MJ, Lohr KN (eds). Committee to Advise the Public Health Service on Clinical Practice Guidelines, Institute of Medicine. Clinical Practice Guidelines. Directions for a New Program. National 
Academy Press, Washington, 1990.

18. McGlynn EA, Asch SM, Adams J, Keesey J, Hicks J, DeCristofaro A, Kerr EA. The quality of health care delivered to adults in the United States. NEJM 2003 348:2635-2645.

19. FitzGerald JM, Boulet LP, Mclvor RA, Zimmerman S, Chapman KR. Asthma control in Canada remains suboptimal: The Reality of Asthma Control (TRAC) study. Can Respir ] 2006, 13:253-259.

20. Brown LC, Johnson JA, Majumdar SR, Tsuyuki RT, McAlister FA. Evidence of suboptimal management of cardiovascular risk in patients with type 2 diabetes mellitus and symptomatic atherosclerosis. CMA] 2004, 171:1189-1192.

21. Roberts VI, Esler CN, Harper WM. What impact have NICE guidelines had on the trends of hip arthroplasty since their publication? J Bone Joint Surg 2007, 89:864-867.

22. Milchak JL, Carter BL, James PA, Ardery $\mathrm{G}$. Measuring adherence to practice guidelines for management of hypertension. Hypertension 2004, 44:602-608.

23. Grol R. Successes and failures in the implementation of evidence-based guidelines for clinical practice. Med Care 2001; 39:II46-II54.

24. Grol R, Grimshaw J. From best evidence to best practice: Effective implementation of change in patients' care. Lancet 2003; 362:1225-1230.

25. Manchikanti L, Singh V, Helm S, Schultz DM, Datta S, Hirsch J. An introduction to an evidence-based approach to interventional techniques in the management of chronic spinal pain. Pain Physician 2009; 12:E1-E33.

26. Manchikanti L, Benyamin RM, Helm S, Hirsch JA. Evidence-based medicine, systematic reviews, and guidelines in interventional pain management: Part 3: Systematic reviews and meta-analysis of randomized trials. Pain Physician 2009; 12:35-72.

27. Manchikanti L, Derby R, Wolfer LR, Singh V, Datta S, Hirsch JA. Evidencebased medicine, systematic reviews, and guidelines in interventional pain management: Part 7: Systematic reviews and meta-analyses of diagnostic accuracy studies. Pain Physician 2009; 12:929-963.

28. Manchikanti L, Datta S, Derby R, Wolfer LR, Benyamin RM, Hirsch JA. A critical review of the American Pain Society clinical practice guidelines for interventiona techniques: Part 1. Diagnostic interventions. Pain Physician 2010; 13:E141-E174.
29. Manchikanti L, Datta S, Gupta S, Munglani R, Bryce DA, Ward SP, Benyamin RM, Sharma ML, Helm II S, Fellows B, Hirsch JA. A critical review of the American Pain Society clinical practice guidelines for interventional techniques: Part 2. Therapeutic interventions. Pain Physician 2010; 13:E215-E264.

30. Manchikanti L, Falco FJE, Boswell MV, Hirsch JA. Facts, fallacies, and politics of comparative effectiveness research: Part 1. Basic considerations. Pain Physician 2010; 13:E23-E54.

31. Manchikanti L, Falco FJE, Boswell MV Hirsch JA. Facts, fallacies, and politics of comparative effectiveness research: Part 2. Implications for interventional pain management. Pain Physician 2010; 13:E55-E79.

32. Chou R, Atlas SJ, Loeser JD, Rosenquist RW, Stanos SP. Guideline warfare over interventional therapies for low back pain: Can we raise the level of discourse? J Pain 2011; 12:833-839.

33. Eden J, Wheatley B, McNeil B, Sox $\mathrm{H}$. Knowing What Works in Health Care: $A$ Roadmap for the Nation. National Academies Press, Washington, DC, 2008.

34. American College of Occupational and Environmental Medicine. Low Back Disorders Chapter. In: Occupational Medicine Practice Guidelines: Evaluation and Management of Common Health Problems and Functional Recovery of Workers. Second Edition. American College of Occupational and Environmental Medicine, Elk Grove Village, 2007.

35. HAYES, Inc. Independent Health Technology Assessment Company. www. hayesinc.com

36. Dennison PL, Kennedy CW. Official Disability Guidelines. 16th ed. Work Loss Data Institute, Encinitas, 2011.

37. Phurrough S, Salive M, O'Connor D, Schafer J. Decision Memo for Thermal Intradiscal Procedures. 2008 [cited September 30, 2008]. www.cms. $\mathrm{hhs}$.gov/mcd/viewdecision me-

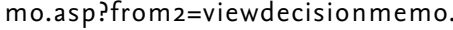
asp\&id $=215 \&$

38. Phurrough S, Salive M, O'Connor D, Schafer J. Proposed Coverage Decision Memorandum for Lumbar Artificial Disc Replacement. [cited May 25, 2007]. www1.cms.hhs. gov/mcd/viewdraftdecisionmemo. asp? from $2=$ viewdraftdecisionmemo. asp\&id $=197 \&$

39. Centers for Medicare and Medicaid Services (CMS). Health Technology Assessment (HTA) Database: Percutaneous ky- phoplasty for vertebral fractures caused by osteoporosis and malignancy. Blue Cross Blue Shield Association (BCBS) Chicago, 2005.

40. Anthem Blue Cross Blue Shield (BCBS) Health and Medical Insurance. www.anthem.com

41. Aetna Health and Medical Insurance. www.aetna.com/index.htm

42. Manchikanti L, Boswell MV, Singh V Benyamin RM, Fellows B, Abdi S, Buenaventura RM, Conn A, Datta S, Derby R, Falco FJE, Erhart S, Diwan S, Hayek SM, Helm S, Parr AT, Schultz DM, Smith HS, Wolfer LR, Hirsch JA. Comprehensive evidence-based guidelines for interventional techniques in the management of chronic spinal pain. Pain Physician 2009; 12:699-802.

43. Cigna Health and Medical Insurance. www.cigna.com

44. ECRI Institute. www.ecri.org

45. Health Technology Assessment, Washington State Health Care Authority. Spinal Injections. Final Report. Spectrum Research, Inc., December 14, 2010. www.hta.hca.wa.gov/documents/spinal_injection_final_report.pdf

46. Manchikanti L, Abdi S, Atluri S, Balog CC, Benyamin RM, Boswell MV, Brown KR, Bruel BM, Bryce DA, Burks PA, Burton AW, Calodney AK, Caraway DL, Cash KA, Christo PJ, Damron KS, Datta S, Deer TR, Diwan S, Eriator I, Falco FJE, Fellows F, Geffert S, Gharibo CG, Glaser SE, Grider JS, Hameed H, Hameed M, Hansen H, Harned ME, Hayek SM, Helm II S, Hirsch JA, Janata JW, Kaye AD, Kaye AM, Kloth DS, Koyyalagunta D, Lee M, Malla Y, Manchikanti KN, McManus CD, Pampati V, Parr AT, Pasupuleti R, Patel VB, Sehgal N, Silverman SM, Singh V, Smith HS, Snook LT, Solanki DR, Tracy DH, Vallejo R, Wargo BW. American Society of Interventional Pain Physicians (ASIPP) guidelines for responsible opioid prescribing in chronic non-cancer pain: Part I - Evidence assessment. Pain Physician 2012; 15:S1-S66.

47. Manchikanti L, Abdi S, Atluri S, Balog CC, Benyamin RM, Boswell MV, Brown KR, Bruel BM, Bryce DA, Burks PA, Burton AW, Calodney AK, Caraway DL, Cash KA, Christo PJ, Damron KS, Datta S, Deer TR, Diwan S, Eriator I, Falco FJE, Fellows F, Geffert S, Gharibo CG, Glaser SE, Grider JS, Hameed H, Hameed $M$, Hansen $H$, Harned ME, Hayek SM, Helm II S, Hirsch JA, Janata JW, Kaye AD, Kaye AM, Kloth DS, Koyyalagunta D, Lee M, Malla Y, Manchikanti KN, McManus CD, Pampati V, Parr AT, Pasupule- 
ti R, Patel VB, Sehgal N, Silverman SM, Singh V, Smith HS, Snook LT, Solanki DR, Tracy DH, Vallejo R, Wargo BW. American Society of Interventional Pain Physicians (ASIPP) guidelines for responsible opioid prescribing in chronic non-cancer pain: Part 2-Guidance. Pain Physician 2012; 15:S67-S116.

48. The Cochrane Collaboration. Evidence Health Care. www.cochrane.org/docs/ ebm.htm

49. Benzon HT, Connis RT, De Leon-Casasola OA, Glass DD, Korevaar WC, Cynwyd B, Mekhail NA, Merrill DG, Nickinovich DG, Rathmell JP, Sang CN, Simon DL. Practice guidelines for chronic pain management: An updated report by the American Society of Anesthesiologists Task Force on Chronic Pain Management and the American Society of Regional Anesthesia and Pain Medicine. Anesthesiology 2010; 112:810-833.

50. Nelemans PJ, Debie RA, DeVet HC, Sturmans F. Injection therapy for subacute and chronic benign low back pain. Spine (Phila Pa 1976) 2001; 26:501-515.

51. Bigos SJ, Boyer OR, Braen GR, Brown K, Deyo R, Haldeman S, Hart JL, Johnson EW, Keller R, Kido D, Liang $\mathrm{MH}$ Nelson RM, Nordin M, Owen BD, Pope $\mathrm{MH}$, Schwartz RK, Stewart DH, Susman J, Triano JJ, Tripp LC, Turk DC, Watts C, Weinstein JN. Acute Low Back Problems in Adults. Clinical Practice Guideline No. 14, AHCPR Publication No. 950642. Rockville, Maryland. U.S.A., Agency for Health Care Policy and Research, Public Health Service, U.S., Department of Health and Human Services, December, 1994, pp 1-60.

52. Airaksinen O, Brox Jl, Cedraschi C, Hildebrandt J, Klaber-Moffett J, Kovacs F, Mannion AF, Reis S, Staal JB, Ursin H, Zanoli G. Chapter 4: European guidelines for the management of chronic nonspecific low back pain. Eur Spine J 2006; 15:S192-S300.

53. Intradiscal Electrothermal Therapy (IDET). Technology Assessment Update. Washington State Department of Labor and Industries, Office of the Medical Director; September 30, 2003.

54. Chou R, Huffman L. Guideline for the Evaluation and Management of Low Back Pain: Evidence Review. American Pain Society, Glenview, IL, 2009.

www.americanpainsociety.org/uploads/ pdfs/LBPEvidRev.pdf

55. U.S. Department of Health and Human Services, Agency for Healthcare Research and Quality (AHRQ), National
Guideline Clearinghouse Guideline Index. www.guideline.gov/browse/guideline_index.aspx

56. Pinto RZ, Maher CG, Ferreria ML, Hancock M, Oliveira VC, McLachlan AJ, Koes B, Ferreira PH. Epidural corticosteroid injections in the management of sciatica: A systematic review and meta-analysis. Ann Intern Med 2012; doi:10.7326/0003-4819-157-12$201212180-00564$.

57. Francke AL, Smit MC, de Veer AJE, Mistiaen P. Factors influencing the implementation of clinical guidelines for health care professionals. BMC Med Inform Dec Mak 2008; 8:38.

58. Baiardini I, Braido F, Bonini M, Compalati E, Canonica GW. Why do doctors and patients not follow guidelines? Curr Opin Allergy Clin Immunol 2009; 9:228233.

59. Timmermans S, Mauck A. The promises and pitfalls of evidence-based medicine. Health Aff 2005; 24:18-28.

6o. Davis DA, Taylor-Vaisey A. Translating guidelines into practice: A systematic review of theoretic concepts, practical experience and research evidence in the adoption of clinical practice guidelines. CMA] 1997; 157:408-416.

61. Grilli R, Magrini N, Penna A, Mura G, Liberati A. Practice guidelines developed by speciality societies: The need for critical appraisal. Lancet 2000; 355:103-106.

62. Ward JE, Grieco V. Why we need guidelines for guidelines: A study of the quality of clinical practice guidelines in Australia. Med J Aust 1996; 156:574-576.

63. Sackett DL, Rosenberg WM, Gray JA, Haynes RB, Richardson WS. Evidence based medicine: What it is and what it isn't. BM] 1996; 312:71-72.

64. Saarni SI, Gylling HA. Evidence based medicine guidelines: A solution to rationing or politics disguised as science? J Med Ethics 2004; 30:171-175.

65. Hotopf M. The pragmatic randomized controlled trial. Adv Psychiatr Treat 2002; 8:326-333.

66. Williams DD, Garner J. The case against 'the evidence': A different perspective on evidence-based medicine. $\mathrm{Br}$ J Psychiatry 2002; 180:8-12.

67. Hotopf M, Lewis G, Normand C. Putting trials on trial: The costs and consequences of small trials in depression: $\mathrm{A}$ systematic review of methodology. J Epidemiol Community Health 1997; 51:354358.

68. Gagliardi AR, Brouwers MC, Palda VA,
Lemieux-Charles L, Grimshaw JM. How can we improve guideline use? A conceptual framework of implementability. Implement Sci 2011; 6:26.

69. Alonso-Coello P, Martínez García L, Carrasco JM, Solà I, Qureshi S, Burgers JS; Updating Guidelines Working Group. The updating of clinical practice guidelines: Insights from an international survey. Implement Sci 2011; 6:107.

70. Qaseem A, Forland F, Macbeth F, Ollenschläger $G$, Phillips $S$, van der Wees $P$; Board of Trustees of the Guidelines International Network. Guidelines International Network: Toward international standards for clinical practice guidelines. Ann Intern Med 2012; 156:525-531.

71. Song P, Gao J, Kokudo N, Dong J, Tang W. "Knowledge into action" - Exploration of an appropriate approach for constructing evidence-based clinical practice guidelines for hepatocellular carcinoma. Biosci Trends 2012; 6:147-152.

72. Sniderman AD, Furberg $C D$. Why guideline - making requires reform. JAMA 2009; 301:429-431.

73. Eden J, Wheatley B, McNeil B, Sox H. Developing trusted clinical practice guidelines. In: Knowing What Works in Health Care: A Roadmap for the Nation. National Academies Press, Washington, DC, 2008, pp 121-152.

74. Steinbrook R. Guidance for guidelines. N Engl J Med 2007; 356:331-333.

75. Grimshaw JM, Russell IT. Effect of clinical guidelines on medical practice: $A$ systematic review of rigorous evaluations. Lancet 1993; 342:1317-1322.

76. Mitchell JB, Ballard DJ, Whisnant JP, Ammering CJ, Samsa GP, Matchar DB. What role do neurologists play in determining the costs and outcomes of stroke patients? Stroke 1996; 27:19371943.

77. Wong JH, Findlay JM, Suarez-Almazor ME. Regional performance of carotid endarterectomy. Appropriateness, outcomes, and risk factors for complications. Stroke 1997; 28:891-898.

78. Gill P, Dowell AC, Neal RD, Smith N, Heywood P, Wilson AE. Evidence based general practice: $A$ retrospective study of interventions in one training practice. BMJ 1996; 30:819-821.

79. Manchikanti L, Falco FJE, Singh V, Pampati V, Parr AT, Benyamin RM, Fellows $B$, Hirsch JA. Utilization patterns of interventional techniques in managing chronic pain in the Medicare population: Analysis of growth from 2000 to 2011. Pain Physician 2012; 15:E969-E982. 
8o. Manchikanti L, Singh V, Caraway DL, Benyamin RM, Hirsch JA. Medicare physician payment systems: Impact of 2011 schedule on interventional pain management. Pain Physician 2011; 14:E5-E33.

81. Manchikanti L, Hirsch JA. Medicare physician payment rules for 2011: A primer for the neurointerventionalist. ] Neurointervent Surg 2011; 3:399-402.

82. Manchikanti L, Hirsch JA. Medicare physician payment rules for 2011: A primer for the neurointerventionalist. AJNR Am J Neuroradiol 2011; 32:E101-E104.

83. Manchikanti L, Singh V, Caraway DL, Benyamin RM, Falco FJE, Hirsch JA. Physician payment outlook for 2012: Déjà Vu. Pain Physician 2012; 15:E27-E52.

84. Manchikanti L, Hirsch JA. Physician payment outlook for 2012. ] Neurolntervent Surg 2012; 4:463-467.

85. Manchikanti L, Singh V, Hirsch JA. Saga of payment systems of ambulatory surgery centers for interventional techniques: An update. Pain Physician 2012; 15:109-130.

86. Manchikanti L, Parr AT, Singh V, Fellows B. Ambulatory surgery centers and interventional techniques: A look at long-term survival. Pain Physician 2011; 14:E177-E215.

87. Manchikanti L, Pampati V, Falco FJE, Hirsch JA. Growth of spinal interventional pain management techniques: Analysis of utilization trends and Medicare expenditures 2000 to 2008. Spine (Phila Pa 1976) 2012 July 11 [Epub ahead of print].

88. Abbott ZI, Nair KV, Allen RR, Akuthota VR. Utilization characteristics of spinal interventions. Spine ] 2012; 1:35-43.

89. US Department of Health and Human Services. Office of Inspector General (OIG). Medicare Payments for Facet Joint Injection Services (OEI-05-0700200). September 2008. www.oig.hhs. gov/oei/reports/oei-05-07-00200.pdf

90. US Department of Health and Human Services. Office of Inspector General (OIG). Inappropriate Medicare Payments for Transforaminal Epidural Injection Services (OEl-05-09-00030). August 2010. http://oig.hhs.gov/oei/reports/oei-05-09-00030.pdf

91. Centers for Medicare and Medicaid Services. www.cms.hhs.gov

92. Department of Health and Human Services. Office of the Inspector General. Prevalence and Qualifications of Nonphysicians Who Performed Medicare Physician Services. August 2009 http://oig.hhs. gov/oei/reports/oei-09-06-00430.pdf

93. Noridian Administrative Services, Medicare Part B, Paravertebral Facet Joint Blockade - Effective November 26, 2012. www. noridianmedicare.com/provider/updates/docs/paravertebral_facet_ joint_nerve_blockade.pdf\% ${ }_{3} f$

94. Makhinson M. Biases in the evaluation of psychiatric clinical evidence. J Nerv Ment Dis 2012; 200:76-82.

95. Cymet T. Evidence-based medicine: How it is different from what we have always done? Md Med 2012; 13:10.

96. Greenhalgh T. Why do we always end up here? Evidence-based medicine's conceptual cul-de-sacs and some off-road alternative routes. J Prim Health Care 2012; 4:92-97.

97. Audrey S. Qualitative research in evidence-based medicine: Improving decision-making and participation in randomized controlled trials of cancer treatments. Palliat Med 2011; 25:758-765.

98. Croft P, Malmivaara A, van Tulder M. The pros and cons of evidence-based medicine. Spine (Phila Pa 1976) 2011; 36:E1121-E1125.

99. He J, Du L, Liu G, Fu J, He X, Yu J, Shang L. Quality assessment of reporting of randomization, allocation concealment, and blinding in traditional Chinese medicine RCTs: A review of 3159 RCTs identified from 260 systematic reviews. Trials 2011; 12:122.

100. Zwolsman S, Te Pas E, Hooft L, Wieringa-de Waard M, van Dijk N. Barriers to GPs' use of evidence-based medicine: A systematic review. $\mathrm{Br}$ J Gen Pract 2012; 62:e511-e521.

101. Villas Boas PJ, Spagnuolo RS, Kamegasawa A, Braz LG, Polachini do Valle A, Jorge EC, Yoo HH, Cataneo AJ, Corrêa I, Fukushima FB, do Nascimento P, Módolo NS, Teixeira MS, de Oliveira Vidal EI, Daher SR, El Dib R. Systematic reviews showed insufficient evidence for clinical practice in 2004: What about in 2011? The next appeal for the evidencebased medicine age. J Eval Clin Pract 2012; [Epub ahead of print].

102. Varma J, Rodriguez R, Mansi IA. Reasoning and evidence-based medicine: Common pitfalls. South Med J 2012; 105:167-172.

103. Rosner AL. Evidence-based medicine: Revisiting the pyramid of priorities. J Bodyw Mov Ther 2012; 16:42-49.

104. Rhee JS, Daramola OO. No need to fear evidence-based medicine. Arch Facial Plast Surg 2012; 14:89-92.
105. Woolf S, Schünemann HJ, Eccles MP, Grimshaw JM, Shekelle P. Developing clinical practice guidelines: Types of evidence and outcomes; values and economics, synthesis, grading, and presentation and deriving recommendations. Implement Sci 2012; 7:61.

106. Shekelle PG, Woolf SH, Eccles M, Grimshaw J. Clinical guidelines: Developing guidelines. BMJ 1999; 318:593-596.

107. National Institute for Health and Clinical Excellence (NICE).

www.nice.org.uk

108. Brouwers MC, Kho ME, Browman GP, Burgers JS, Cluzeau F, Feder G, Fervers B, Graham ID, Hanna SE, Makarski J; AGREE Next Steps Consortium, Development of the AGREE II, part 2: Assessment of validity of items and tools to support application. CMA] 2010; 182:E472-E478.

109. World Health Organization. Global Programme on Evidence for Health Policy. Geneva: World Health Organization, Geneva, 2003.

http://whqlibdoc.who.int/hq/2003/EIP_ GPE_EQC_2003_1.pdf

110. Scottish Intercollegiate Guidelines Network. SIGN 50: A Guideline Developer's Handbook. Scottish Intercollegiate Guidelines Network Edinburgh, Scotland, 2008.

www.sign.ac.uk/guidelines/fulltext/50/ index.html

111. National Health and Medical Research Council. Procedures and Requirements for Meeting the 2011 NHMRC Standard for Clinical Practice Guidelines.National Health and Medical Research Council, Melbourne, Australia, 2011.

112. Eden J, Levit L, Berg A, Morton S (eds); Committee on Standards for Systematic Reviews of Comparative Effectiveness Research; Institute of Medicine. Finding What Works in Health Care. Standards for Systematic Reviews. The National Academies Press, Washington, DC, 2011.

113. Kuehn BM. IOM sets out "gold standard" practices for creating guidelines, systematic reviews. JAMA 2011; 305:1846-1848.

114. Manchikanti L. Singh V, Datta S, Cohen SP, Hirsch JA. Comprehensive review of epidemiology, scope, and impact of spinal pain. Pain Physician 2009: 12:E35E7o.

115. The National Uniform Claims Committee. Specialty Designation for Interventional Pain Management- og. www. cms.hhs.gov/transmittals/Downloads/ 
ri77gb3.pdf

116. Medicare Payment Advisory Commission Report to the Congress. Paying for Interventional Pain Services in Ambulatory Settings. December 2001.

117. Committee on Comparative Effectiveness Research Prioritization, Institute of Medicine. Initial National Priorities for Comparative Effectiveness Research. National Academy of Sciences, Washington DC, 2009.

118. Wright RW, Brand RA, Dunn W, Spindler KP. How to write a systematic review. Clin Orthop Relat Res 2007; 455:2329.

119. Pai M, McCulloch M, Gorman JD, Pai $N$, Enanoria W, Kennedy G, Tharyan $P$, Colford JM. Systematic reviews and meta-analyses: An illustrated, step-by-step guide. Natl Med J India 2004; 17:86-95.

120. World Health Organization. International Clinical Trials Registry Platform (ICTRP). 2007. www.who.int/entity/ictrp/ en/

121. Altman DG, Schulz KF, Moher D, Egger M, Davidoff F, Elbourne D, Gøtzsche PC, Lang T; CONSORT GROUP (Consolidated Standards of Reporting Trials). The revised CONSORT statement for reporting randomized trials: Explanation and elaboration. Ann Intern Med 2001; 134:663-694.

122. Zwarenstein $M$, Treweek $S$, Gagnier J, Altman DG, Tunis S, Haynes B, Oxman AD, Moher D; CONSORT group; Pragmatic Trials in Healthcare (Practihc) group. Improving the reporting of pragmatic trials: An extension of the CONSORT statement. BMJ 2008; 337:a2390.

123. Stroup DF, Berlin JA, Morton SC, Olkin I, Williamson GD, Rennie D, Moher D, Becker BJ, Sipe TA, Thacker SB. Metaanalysis of observational studies in epidemiology: A proposal for reporting. Meta-analysis of Observational Studies in Epidemiology (MOOSE) group. JAMA 2000; 283:2008-2012.

124. Bossuyt PM, Reitsma JB, Bruns DE, Gatsonis CA, Glasziou PP, Irwig LM, Lijmer JG, Moher D, Rennie D, de Vet HC; STARD Group. Towards complete and accurate reporting of studies of diagnostic accuracy: The STARD initiative. Fam Pract 2004; 21:4-10.

125. Merskey H, Bogduk N; Task Force on Taxonomy of the International Association for the Study of Pain. Classification of Chronic Pain: Descriptions of Chronic Pain Syndromes and Definition of Pain Terms. 2nd ed. IASP Press, Seattle, WA 1994.
126. Institute of Medicine (IOM). Relieving Pain in America: A Blueprint for Transforming Prevention, Care, Education, and Research. The National Academies Press, Washington, DC, 2011.

127. Freburger JK, Holmes GM, Agans RP, Jackman AM, Darter JD, Wallace AS, Castel LD, Kalsbeek WD, Carey TS. The rising prevalence of chronic low back pain. Arch Intern Med 2009; 169:251-258.

128. Hoy DG, Bain C, Williams G, March L, Brooks $\mathrm{P}$, Blyth F, Woolf A, Vos T, Buchbinder R. A systematic review of the global prevalence of low back pain. Arthritis Rheum 2012; 64:2028-2037.

129. Hoy D, Brooks P, Blyth F, Buchbinder R. The epidemiology of low back pain. Best Pract Res Clin Rheumatol 2010; 24:769781.

130. Hoy DG, Protani M, De R, Buchbinder $R$. The epidemiology of neck pain. Best Pract Res Clin Rheumatol 2010; 24:783792.

131. Cassidy JD, Carroll LJ, Côté P. The Saskatchewan Health and Back Pain Survey. The prevalence of low back pain and related disability in Saskatchewan adults. Spine (Phila Pa 1976) 1998; 23:1860-1867.

132. Côté P, Cassidy JD, Carroll L. The Saskatchewan Health and Back Pain Survey. The prevalence of neck pain and related disability in Saskatchewan adults. Spine (Phila Pa 1976) 1998; 23:1689-1698.

133. Martin BI, Deyo RA, Mirza SK, Turner JA, Comstock BA, Hollingworth W, Sullivan SD. Expenditures and health status among adults with back and neck problems. JAMA 2008; 299:656-664.

134. Martin BI, Turner JA, Mirza SK, Lee MJ, Comstock BA, Deyo RA. Trends in health care expenditures, utilization, and health status among US adults with spine problems, 1997-2006. Spine (Phila Pa 1976) 2009: 34:2077-2084.

135. Leigh JP. Economic burden of occupational injury and illness in the United States. Milbank Q 2011; 89:728-772.

136. Bhushan A, Leigh JP. National trends in occupational injuries before and after 1992 and predictors of workers' compensation costs. Public Health Rep 2011; 126:625-634.

137. Gaskin DJ, Richard P. The economic costs of pain in the United States. J Pain 2012; 13:715-724.

138. Becker A, Held H, Redaelli M, Strauch K, Chenot JF, Leonhardt C, Keller S, Baum $E$, Pfingsten $M$, Hildebrandt J, Basler HD, Kochen MM, Donner-Banzhoff N. Low back pain in primary care: Costs of care and prediction of future health care utilization. Spine (Phila Pa 1976) 2010; 35:1714-1720.

139. Pryce R, Johnson M, Goytan M, Passmore $\mathrm{S}$, Berrington N, Kriellaars D. Relationship between ambulatory performance and self-rated disability in patients with lumbar spinal stenosis. Spine (Phila Pa 1976) 2012; 37:1316-1323.

140. Hoy DG, March L, Brooks P, Woolf A, Blyth F, Vos T, Buchbinder R. Measuring the global burden of low back pain. Best Pract Res Clin Rheumatol 2010; 24:155165.

141. Cecchi F, Debolini P, Lova RM, Macchi C, Bandinelli S, Bartali B, Lauretani F, Benvenuti E, Hicks G, Ferrucci L. Epidemiology of back pain in a representative cohort of Italian persons 65 years of age and older: The InCHIANTI study. Spine (Phila Pa 1976) 2006; 31:1149-1155.

142. Bressler HB, Keyes WJ, Rochon PA, Badley $\mathrm{E}$. The prevalence of low back pain in the elderly. A systematic review of the literature. Spine (Phila Pa 1976) 1999; 24:1813-1819.

143. Leigh JP, Markowitz SB, Fahs M, Shin C, Landrigan PJ. Occupational injury and illness in the United States. Estimates of costs, morbidity, and mortality. Arch Inter Med 1997; 157:1557-1568.

144. Leigh JP, Waehrer G, Miller TR, McCurdy SA. Costs differences across demographic groups and types of occupational injuries and illnesses. Am J Ind Med 2006; 49:845-853.

145. Dunning KK, Davis KG, Cook C, Kotowski SE, Hamrick C, Jewell G, Lockey J. Costs by industry and diagnosis among musculoskeletal claims in a state workers compensation system: 1999-2004. Am J Ind Med 2010; 53:276-284.

146. Deyo RA, Mirza SK, Turner JA, Martin BI. Overtreating chronic back pain: Time to back off? J Am Board Fam Med 2009; 22:62-68.

147. Deyo RA, Smith DH, Johnson ES, Donovan M, Tillotson CJ, Yang X, Petrik AF, Dobscha SK. Opioids for back pain patients: Primary care prescribing patterns and use of services. J Am Board Fam Med 2011; 24:717-727.

148. Ritzwoller DP, Crounse L, Shetterly S, Rublee D. The association of comorbidities, utilization and costs for patients identified with low back pain. BMC Musculoskelet Disord 2006; 7:72.

149. Du J, Leigh JP. Incidence of workers compensation indemnity claims across socio-demographic and job characteristics. Am J Ind Med 2011; 54:758-770.

150. Leigh JP, Hubert HB, Romano PS. Life- 
style risk factors predict healthcare costs in an aging cohort. Am J Prev Med 2005c; 29:379-387.

151. Webb R, Brammah T, Lunt $M$, Urwin $M$, Allison T, Symmons D. Prevalence and predictors of intense, chronic, and disabling neck and back pain in the UK general population. Spine (Phila Pa 1976) 2003; 28:1195-1202.

152. Akyüz G, Ozkök O. Evidence based rehabilitation in chronic pain syndromes. Agri 2012; 24:97-103.

153. Ohayon MM, Stingl JC. Prevalence and comorbidity of chronic pain in the German general population. J Psychiatr Res 2012; 46:444-450.

154. Haldeman S, Kopansky-Giles D, Hurwitz EL, Hoy D, Mark Erwin W, Dagenais S, Kawchuk G, Strömqvist B, Walsh $\mathrm{N}$. Advancements in the management of spine disorders. Best Pract Res Clin Rheumatol 2012; 26:263-280.

155. Ratcliffe GE, Enns MW, Belik S, Sareen J. Chronic pain conditions and suicidal ideation and suicide attempts. An epidemiologic perspective. Clin J Pain 2008; 24:204-210.

156. Martin BI, Mirza SK, Comstock BA, Gray DT, Kreuter W, Deyo RA. Are lumbar spine reoperation rates falling with greater use of fusion surgery and new surgical technology? Spine (Phila Pa 1976) 2007; 32:2119-2126.

157. Saastamoinen $P$, Leino-Arjas $P$, Laaksonen M, Lahelma E. Socio-economic differences in the prevalence of acute, chronic and disabling chronic pain among ageing employees. Pain 2005; 114:364-371.

158. Okoro CA, Zhao G, Li C, Balluz LS. Use of complementary and alternative medicine among USA adults with functional limitations: For treatment or general use? Complement Ther Med 2011; 19:208215

159. Okoro CA, Zhao G, Li C, Balluz LS. Has the use of complementary and alternative medicine therapies by U.S. Adults with chronic disease-related functional limitations changed from 2002 to 2007? J Altern Complement Med 2012 Oct 16. [Epub ahead of print]

160. Zodet MW, Stevans JM. The 2008 Prevalence of Chiropractic Use in the US Adult Population. J Manipulative Physiol Ther 2012; 35:580-588.

161. Stevans JM, Zodet MW. Clinical, demographic, and geographic determinants of variation in chiropractic episodes of care for adults using the 2005-2008 medical expenditure panel survey. J Manipulative Physiol Ther 2012; 35:589-599.

162. Davis MA, Sirovich BE, Weeks WB. Utilization and expenditures on chiropractic care in the United States from 1997 to 2006. Health Serv Res 2010; 45:748-761.

163. Machlin SR, Chevan J, Yu WW, Zodet MW. Determinants of utilization and expenditures for episodes of ambulatory physical therapy among adults. Phys Ther. 2011 Jul;91(7):1018-29.

164. Fritz JM, Childs JD, Wainner RS, Fly$\mathrm{nn}$ TW. Primary care referral of patients with low back pain to physical therapy: Impact on future health care utilization and costs. Spine (Phila Pa 1976) 2012; 37:2114-2121.

165. Freburger JK, Carey TS, Holmes GM. Physical therapy for chronic low back pain in North Carolina: Overuse, underuse, or misuse? Phys Ther 2011; 91:484495.

166. Chevan J, Riddle DL. Factors associated with care seeking from physicians, physical therapists, or chiropractors by persons with spinal pain: A populationbased study. J Orthop Sports Phys Ther 2011; 41:467-476.

167. Hansen SF, S Laursen AL, Jensen TS, Leboeuf-Yde C, Hestbæk L. The Nordic maintenance care program: What are the indications for maintenance care in patients with low back pain? A survey of the members of the Danish Chiropractors' Association. Chiropr Osteopat 2010; 18:25.

168. Bokov A, Istrelov A, Skorodumov A, Aleynik A, Simonov A, Mlyavykh S. An analysis of reasons for failed back surgery syndrome and partial results after different types of surgical lumbar nerve root decompression. Pain Physician 2011; 14:545-557.

169. Taylor RS. Spinal cord stimulation in complex regional pain syndrome and refractory neuropathic back and leg pain/failed back surgery syndrome: Results of a systematic review and metaanalysis. J Pain Symptom Manage 2006; 31:S13-S19.

170. Fritsch EW, Heisel J, Rupp S. The failed back surgery syndrome. Reasons, intraoperative findings, and long-term results: A report of 182 operative treatments. Spine (Phila Pa 1976) 1996; 21:626633.

171. Osterman H, Sund R, Seitsalo S, Keskimaki I. Risk of multiple reoperations after lumbar discectomy: A populationbased study. Spine (Phila Pa 1976) 2003;
28:621-627.

172. Bono CM, Lee CK. Critical analysis of trends in fusion for degenerative disc disease over the past 20 years: Influence of technique of fusion rate and clinical outcome. Spine (Phila Pa 1976) 2004; 29:455-463.

173. Hoppenstein R. A new approach to the failed back syndrome. Spine (Phila Pa 1976) 1980; 5:371-379.

174. Social Security Administration. Annual Statistical Report on the Social Security Disability Insurance Program, 2011. Baltimore, MD, Office of Research Evaluation and Statistics, 2011. www.ssa.gov/ policy/docs/statcomps/di_asr/2011/di_ asril.pdf

175. Ricci JA, Stewart WF, Chee E, Leotta C, Foley K, Hochberg MC. Back pain exacerbations and lost productive time costs in United States workers. Spine (Phila Pa 1976) 2006; 31:3052-3060.

176. Walker BF, Muller R, Grant WD. Low back pain in Australian adults: The economic burden. Asia Pac J Public Health 2003; 15:79-87.

177. Jhawar BS, Fuchs CS, Colditz GA, Stampfer MJ. Cardiovascular risk factors for physician-diagnosed lumbar disc herniation. Spine ] 2006; 6:684-691.

178. Gray DT, Deyo RA, Kreuter W, Mirza SK, Heagerty PJ, Comstock BA, Chan L. Population-based trends in volumes and rates of ambulatory lumbar spine surgery. Spine (Phila Pa 1976) 2006; 31:1957-1963.

179. Luo X, Pietrobon R, Hey L. Patterns and trends in opioid use among individuals with back pain in the United States. Spine (Phila Pa 1976) 2004; 29:884-890.

180. Ivanova JI, Birnbaum HG, Schiller M, Kantor E, Johnstone BM, Swindle RW. Real-world practice patterns, healthcare utilization, and costs in patients with low back pain: The long road to guideline-concordant care. Spine J 2011; 11:622-632.

181. Manchikanti L, Ailinani H, Koyyalagunta D, Datta S, Singh V, Eriator I, Sehgal N, Shah RV, Benyamin RM, Vallejo R, Fellows $B$, Christo PJ. A systematic review of randomized trials of long-term opioid management for chronic non-cancer pain. Pain Physician 2011; 14:91-121.

182. Colson J, Koyyalagunta D, Falco FJE, Manchikanti L. A systematic review of observational studies on the effectiveness of opioid therapy for cancer pain. Pain Physician 2011; 14:E85-E102.

183. Koyyalagunta D, Burton AW, Toro MP, 
Driver L, Novy DM. Opioid abuse in cancer pain: Report of two cases and presentation of an algorithm of multidisciplinary care. Pain Physiciain 2011; 14:E361-E371.

184. Manchikanti L, Helm II S, Fellows B, Janata JW, Pampati V, Grider JS, Boswell MV. Opioid epidemic in the United States. Pain Physician 2012; 15:ES9-ES38.

185. Christo PJ, Manchikanti L, Ruan X, Bottros $M$, Hansen $H$, Solanki D, Jordan AE, Colson J. Urine drug testing in chronic pain. Pain Physician 2011; 14:123-143.

186. Koyyalagunta D, Bruera E, Solanki DR, Nouri KH, Burton AW, Toro MP, Bruel BM, Manchikanti L. A systematic review of randomized trials on the effectiveness of opioids for cancer pain. Pain Physician 2012; 15:ES39-ES58.

187. Daitch J, Frey ME, Silver D, Mitnick C, Daitch D, Pergolizzi J Jr. Conversion of chronic pain patients from full-opioid agonists to sublingual buprenorphine. Pain Physician 2012; 15:ES59-ES66.

188. Sehgal N, Manchikanti L, Smith HS. Prescription opioid abuse in chronic pain: A review of opioid abuse predictors and strategies to curb opioid abuse. Pain Physician 2012; 15:ES67-ES92.

189. Smith HS. Opioids and neuropathic pain. Pain Physician 2012; 15:ES93-ES110.

190. De Maddalena C, Bellini M, Berra M, Meriggiola MC, Aloisi AM. Opioid-induced hypogonadism: why and how to treat it. Pain Physician 2012; 15:ES111ES118.

191. Owen GT, Burton AW, Schade CM, Passik $S$. Urine drug testing: current recommendations and best practices. Pain Physician 2012; 15:ES119-ES133.

192. Wang H, Fischer C, Chen G, Weinsheimer N, Gantz S, Schiltenwolf M. Does long-term opioid therapy reduce pain sensitivity of patients with chronic low back pain? Evidence from quantitative sensory testing. Pain Physician 2012; 15: ES135-ES143.

193. Smith HS, Elliott JA. Opioid-induced androgen deficiency (OPIAD). Pain Physician 2012; 15:ES145-ES156

194. Krashin DL, Merrill JO, Trescot AM. Opioids in the management of HIV-related pain. Pain Physician 2012; 15:ES157ES168.

195. Goodin A, Blumenschein K, Freeman PR, Talbert J. Consumer/patient encounters with prescription drug monitoring programs: evidence from a Medicaid population. Pain Physician 2012; 15:ES169-ES175.
196. Atluri S, Akbik H, Sudarshan G. Prevention of opioid abuse in chronic non-cancer pain: an algorithmic, evidence based approach. Pain Physician 2012; 15:ES177ES189.

197. Fischer B, Argento E. Prescription opioid related misuse, harms, diversion and interventions in Canada: A review. Pain Physician 2012; 15:ES191-203.

198. Nijs J, Kosek E, Van Oosterwijck J, Meeus $M$. Dysfunctional endogenous analgesia during exercise in patients with chronic pain: to exercise or not to exercise? Pain Physician 2012; 15:ES205-ES213.

199. Wilhelmi BG, Cohen SP. A framework for "driving under the influence of drugs" policy for the opioid using driver. Pain Physician 2012; 15:ES215-ES230.

200. Colson J, Helm S, Silverman SM. Officebased opioid dependence treatment. Pain Physician 2012; 15:ES231-ES236.

201. Pesce A, West C, Gonzales E, Rosenthal M, West R, Mikel C, Almazan P, Latyshev $S$, Horn P. Illicit drug use correlates with negative urine drug test results for prescribed hydrocodone, oxycodone, and morphine. Pain Physician 2012; 15:E687E692.

202. Korkmazsky M, Ghandehari J, Sanchez A, Lin HM, Pappagallo M. Feasibility study of rapid opioid rotation and titration. Pain Physician 2011; 14:71-82.

203. Manchikanti L, Singh V, Caraway DL, Benyamin RM. Breakthrough pain in chronic non-cancer pain: Fact, fiction, or abuse. Pain Physician 2011; 14:E103E117.

204. Solanki DR, Koyyalagunta D, Shah RV, Silverman SM, Manchikanti L. Monitoring opioid adherence in chronic pain patients: Assessment of risk of substance misuse. Pain Physician 2011; 14:E119-E131.

205. Lee $M$, Silverman $S M$, Hansen $\mathrm{H}, \mathrm{Pa}$ tel VB, Manchikanti L. A comprehensive review of opioid-induced hyperalgesia. Pain Physician 2011; 14:145-161.

206. Manchikanti L, Vallejo R, Manchikanti KN, Benyamin RM, Datta S, Christo PJ. Effectiveness of long-term opioid therapy for chronic non-cancer pain. Pain Physician 2011; 14:E133-E156.

207. Manchikanti L, Malla Y, Wargo BW, Fellows B. Comparative evaluation of the accuracy of immunoassay with liquid chromatography tandem mass spectrometry (LC/MS/MS) of urine drug testing (UDT) opioids and illicit drugs in chronic pain patients. Pain Physician 2011; 14:175-187.
208. Pesce A, West C, Rosenthal M, Mikel C, West R, Crews B, Almazan P, Latyshev $S$, Horn PS. Illicit drug use in the pain patient population decreases with continued drug testing. Pain Physician 2011; 14:189-193.

209. Manchikanti L, Malla Y, Wargo BW, Fellows B. Comparative evaluation of the accuracy of benzodiazepine testing in chronic pain patients utilizing immunoassay with liquid chromatography tandem mass spectrometry (LC/MS/MS) of urine drug testing. Pain Physician 2011; 14:259-270.

210. Gupta A, Patton C, Diskina D, Cheatle $M$. Retrospective review of physician opioid prescribing practices in patients with aberrant behaviors. Pain Physician 2011; 14:383-389.

211. Johnson F, Setnik B. Morphine sulfate and naltrexone hydrochloride extended-release capsules: naltrexone release, pharmacodynamics, and tolerability. Pain Physician 2011; 14:391-406.

212. Centers for Disease Control and Prevention. $C D C$ grand rounds: Prescription drug overdoses - a U.S. epidemic. MMWR Morb Mortal Wkly Rep 2012; 61:10-13.

213. Diwan SA, Manchikant L, Benyamin RM, Bryce DA, Geffert S, Hameed H, Sharma ML, Abdi S, Falco FJE. Effectiveness of cervical epidural injections in the management of chronic neck and upper extremity pain. Pain Physician 2012; 15:E405-E434.

214. Benyamin RM, Wang VC, Vallejo R, Singh V, Helm S II. A systematic evaluation of thoracic interlaminar epidural injections. Pain Physician 2012; 15:E497E514.

215. Schultz DM, Zhou X, Singal A, Musley S. Cardiovascular effects of spinal cord stimulation in hypertensive patients. Pain Physician 2011; 14:1-14.

216. Raffaeli W, Sarti D, Demartini L, Sotgiu A, Bonezzi C; Italian Ziconotide Group. Italian registry on long-term intrathecal ziconotide treatment. Pain Physician 2011; 14:15-24.

217. Kim CH, Issa MA. Spinal cord stimulation for the treatment of chronic renal pain secondary to uretero-pelvic junction obstruction. Pain Physician 2011; 14:55-59.

218. Gentile DA, Woodhouse J, Lynch P, Maier J, McJunkin T. Reliability and validity of the Global Pain Scale with chronic pain sufferers. Pain Physician 2011; 14:6170. 
219. Gomes LM, Garcia JB, Ribamar JS Jr Nascimento AG. Neurotoxicity of subarachnoid preservative-free $\mathrm{S}(+)$-ketamine in dogs. Pain Physician 2011; 14:83-90.

220. Smith HS, Harris R, Clauw D. Fibromyalgia: an afferent processing disorder leading to a complex pain generalized syndrome. Pain Physician 2011; 14:E217E245.

221. Deer TR, Smith HS, Burton AW, Pope JE, Doleys DM, Levy RM, Staats PS, Wallace MS, Webster LR, Rauck RL, Cousins M. Comprehensive consensus based guidelines on intrathecal drug delivery systems in the treatment of pain caused by cancer pain. Pain Physician 2011; 14:E283-E312.

222. Hayek SM, Deer TR, Pope JE, Panchal S), Patel VB. Intrathecal therapy for cancer and non-cancer pain. Pain Physician 2011; 14:219-248.

223. Hegarty D, Goroszeniuk T. Peripheral nerve stimulation of the thoracic paravertebral plexus for chronic neuropathic pain. Pain Physician 2011; 14:295-300.

224. Kharkar S, Ambady $P$, Yedatore V, Schwartzman RJ. Intramuscular botulinum toxin $\mathrm{A}(\mathrm{BtxA})$ in complex regional pain syndrome. Pain Physician 2011; 14:311-316.

225. Manchikanti L, Malla Y, Wargo BW, Cash KA, McManus CD, Damron KS, Jackson $\mathrm{SD}$, Pampati V, Fellows B. A prospective evaluation of bleeding risk of interventional techniques in chronic pain. Pain Physician 2011; 14:317-329.

226. Grider JS, Harned ME, Etscheidt MA. Patient selection and outcomes using a low-dose intrathecal opioid trialing method for chronic nonmalignant pain. Pain Physician 2011; 14:343-351.

227. Park CH, Lee SH, Park HS. Lumbar retrodiscal versus post-ganglionic transforaminal epidural steroid injection for the treatment of lumbar intervertebral disc herniations. Pain Physician 2011; 14:353-36o.

228. Kang SS, Hwang BM, Son HJ, Cheong IY, Lee SJ, Lee SH, Chung TY. The dosages of corticosteroid in transforaminal epidural steroid injections for lumbar radicular pain due to a herniated disc. Pain Physician 2011; 14:361-370.

229. Nagda JV, Davis CW, Bajwa ZH, Simopoulos TT. Retrospective review of the efficacy and safety of repeated pulsed and continuous radiofrequency lesioning of the dorsal root ganglion/segmental nerve for lumbar radicular pain. Pain Physician 2011; 14:371-376.
230. Falco FJE, Datta S, Sehgal N, Geffert $\mathrm{S}$, Onyewu $\mathrm{O}$, Singh $\mathrm{V}$, Benyamin RM, Gupta S, Ward SP, Manchikanti L. An update of systematic assessment of diagnostic accuracy of lumbar facet joint nerve blocks. Pain Physician 2012; 15:E868-E908.

231. Smith H. Painful osseous Metastases (POM). Pain Physician 2011; 14:E373$\mathrm{E} 4 \mathrm{O} 3$.

232. Schade CM, Schultz DM, Tamayo N, lyer S, Panken E. Automatic adaptation of neurostimulation therapy in response to changes in patient position: results of the Posture Responsive Spinal Cord Stimulation (PRS) Research Study. Pain Physician 2011; 14:407-417.

233. Kharkar S, Ambady P, Venkatesh Y, Schwartzman RJ. Intramuscular botulinum toxin in complex regional pain syndrome: case series and literature review. Pain Physician 2011; 14:419-424.

234. Manchikanti L, Malla Y, Wargo BW, Fellows B. Infection control practices (safe injection and medication vial utilization) for interventional techniques: Are they based on relative risk management or evidence? Pain Physician 2011; 14:425434.

235. Hirsch AE, Jha RM, Yoo AJ, Saxena A, Ozonoff A, Growney MJ, Hirsch JA. The use of vertebral augmentation and external beam radiation therapy in the multimodal management of malignant vertebral compression fractures. Pain Physician 2011; 14:447-458.

236. Manchikanti L, Malla Y, Wargo BW, Fellows B. Preoperative fasting before interventional techniques: Is it necessary or evidence-based? Pain Physician 2011; 14:459-467.

237. Falco FJE, Manchikanti L, Datta S, Sehgal N, Geffert S, Onyewu O, Zhu J, Coubarous S, Hameed M, Ward SP, Sharma M, Hameed H, Singh V, Boswell MV. An update of the effectiveness of therapeutic lumbar facet joint interventions. Pain Physician 2012; 15:E909-E953.

238. Amr YM. Effect of addition of epidural ketamine to steroid in lumbar radiculitis: one-year follow-up. Pain Physician 2011; 14:475-481.

239. Harned ME, Salles SS, Grider JS. An introduction to trialing intrathecal baclofen in patients with hemiparetic spasticity: a description of 3 cases. Pain Physician 2011; 14:483-489.

240. Smith HS. Painful rheumatoid arthritis. Pain Physician 2011; 14:E427-E458.

241. Gharibo CG, Varlotta GP, Rhame EE, Liu
EC, Bendo JA, Perloff MD. Interlaminar versus transforaminal epidural steroids for the treatment of subacute lumbar radicular pain: a randomized, blinded, prospective outcome study. Pain Physician 2011; 14:499-511.

242. Kim DD, Vakharyia R, Kroll HR, Shuster A. Rates of lead migration and stimulation loss in spinal cord stimulation: a retrospective comparison of laminotomy versus percutaneous implantation. Pain Physician 2011; 14:513-524.

243. Kim CH, Issa MA, Vaglienti RM. Use of observational mechanical gateway connector in spinal cord stimulation trials. Pain Physician 2011; 14:525-530.

244. Boogaard S, Heymans MW, Patijn J, de Vet HC, Faber CG, Peters ML, Loer SA, Zuurmond WW, Perez R. Predictors for persistent neuropathic pain--a Delphi survey. Pain Physician 2011; 14:559-568.

245. Falco FJE, Datta S, Manchikanti L, Sehgal N, Geffert S, Singh V, Smith HS, Boswell MV. An updated review of diagnostic utility of cervical facet joint injections. Pain Physician 2012; 15:E807-E838.

246. Schultz DM, Webster L, Kosek P, Dar U, Tan Y, Sun M. Sensor-driven positionadaptive spinal cord stimulation for chronic pain. Pain Physician 2012; 15:112 .

247. DePalma MJ, Ketchum JM, Saullo TR, Laplante BL. Is the history of a surgical discectomy related to the source of chronic low back pain? Pain Physician 2012; 15:E53-E58.

248. Hao J, Hu Z. Percutaneous cement vertebroplasty in the treatment of symptomatic vertebral hemangiomas. Pain Physician 2012; 15:43-49.

249. Varhabhatla NC, Zuo Z. Rising complication rates after intrathecal catheter and pump placement in the pediatric population: analysis of national data between 1997 and 2006. Pain Physician 2012; 15:65-74.

250. DePalma MJ, Ketchum JM, Saullo T. What is the source of chronic low back pain and does age play a role? Pain Med 2011; 12:224-233.

251. McGreevy K, Williams KA, Christo PJ. Cephalad lead migration following spinal cord stimulation implantation. Pain Physician 2012; 15:E79-E87.

252. Pak J. Autologous adipose tissue-derived stem cells induce persistent bone-like tissue in osteonecrotic femoral heads. Pain Physician 2012; 15:75-85.

253. Birkenmaier C, Baumert S, Schroeder C, Jansson V, Wegener B. A biomechani- 
cal evaluation of the epidural neurolysis procedure. Pain Physician 2012; 15:E89E97.

254. Gazelka HM, Burgher AH, Huntoon MA, Mantilla CB, Hoelzer BC. Determination of the particulate size and aggregation of clonidine and corticosteroids for epidural steroid injection. Pain Physician 2012; 15:87-93.

255. Wegener B, Rieskamp K, Büttner A, Habiyambere $V$, von Schultze-Pellangahr C, Schaffer V, Jansson V, Birkenmaier $C$. Experimental evaluation of the risk of extradiscal thermal damage in intradiscal electrothermal therapy (IDET). Pain Physician 2012; 15:E99-E106.

256. Kim H, Choi YL, Lee DK, Choi SS, Lee IO, Kong $\mathrm{MH}$, Kim NS, Lim SH, Lee $M$. The neurological safety of intrathecal acyclovir in rats. Pain Physician 2012; 15:E107-E113.

257. Magalhaes FN, Dotta L, Sasse A, Teixera MJ, Fonoff ET. Ozone therapy as a treatment for low back pain secondary to herniated disc: a systematic review and meta-analysis of randomized controlled trials. Pain Physician 2012; 15:E115-E129.

258. Wang $W$, Sun $Y H$, Wang $Y Y$, Wang $Y T$, Wang W, Li YQ, Wu SX. Treatment of functional chest pain with antidepressants: a meta-analysis. Pain Physician 2012; 15:E131-E142.

259. Manchikanti L, Malla Y, Wargo BW, Cash KA, Pampati V, Fellows B. A prospective evaluation of complications of 10,000 fluoroscopically directed epidural injections. Pain Physician 2012; 15:131-140.

26o. Stauber B, Ma L, Nazari R. Cardiopulmonary arrest following cervical epidural injection. Pain Physician 2012; 15:147152.

261. Wewalka M, Abdelrahimsai A, Wiesinger GF, Uher EM. CT-guided transforaminal epidural injections with local anesthetic, steroid, and tramadol for the treatment of persistent lumbar radicular pain. Pain Physician 2012; 15:153-159.

262. Wininger KL. Benefits of inferential statistical methods in radiation exposure studies: another look at percutaneous spinal cord stimulation mapping [trialing] procedures. Pain Physician 2012; 15:161-170.

263. Laplante BL, Ketchum JM, Saullo TR, DePalma MJ. Multivariable analysis of the relationship between pain referral patterns and the source of chronic low back pain. Pain Physician 2012; 15:171178.

264. Manchikanti L, Malla Y, Wargo BW, Cash
KA, Pampati V, Fellows B. Complications of fluoroscopically directed facet joint nerve blocks: A prospective evaluation of 7,500 episodes with 43,000 nerve blocks. Pain Physician 2012; 15:E143-E150.

265. Falco FJE, Manchikanti L, Datta S, Wargo BW, Geffert S, Bryce DA, Atluri S, Singh V, Benyamin RM, Sehgal N, Ward S, Helm II S, Gupta S, Boswell MV. Systematic review of therapeutic effectiveness of cervical facet joint interventions: An update. Pain Physician 2012; 15:E839E868.

266. Li J, Feng Y, Han J, Fan B, Wu D, Zhang D, Du D, Li H, Lim J, Wang J, Jin Y, Fu Z. Linguistic adaptation, validation and comparison of 3 routinely used neuropathic pain questionnaires. Pain Physician 2012; 15:179-186.

267. Atluri S, Singh V, Datta S, Geffert S, Sehgal N, Falco FJE. Diagnostic accuracy of thoracic facet joint nerve blocks: An update of the assessment of evidence. Pain Physician 2012; 15:E483-E496.

268. Wolter T, Kieselbach K. Cervical spinal cord stimulation: an analysis of 23 patients with long-term follow-up. Pain Physician 2012; 15:203-212.

269. Lee JH, Lee SH. Clinical effectiveness of percutaneous adhesiolysis using Navicath for the management of chronic pain due to lumbosacral disc herniation. Pain Physician 2012; 15:213-221.

270. Kang SS, Hwang BM, Son $\mathrm{H}$, Cheong IY, Lee SJ, Chung TY. Changes in bone mineral density in postmenopausal women treated with epidural steroid injections for lower back pain. Pain Physician 2012; 15:229-236.

271. Koman G, Alfieri A, Rachingter J, Strauss C, Scheller C. Erectile dysfunction as rare side effect in the simultaneous intrathecal application of morphine and clonidine. Pain Physician 2012; 15:E523E526.

272. Eom KS, Kim TY. Percutaneous vertebroplasty-induced adjacent vertebral compression fracture. Pain Physician 2012; 15:E527-E532.

273. Lee MG, Huh BK, Choi SS, Lee DK, Lim $B G$, Lee M. The effect of epidural resiniferatoxin in the neuropathic pain rat model. Pain Physician 2012; 5:287-296.

274. Gupta G, Radhakrishna M, Chankowsky J, Asenjo JF. Methylene blue in the treatment of discogenic low back pain. Pain Physician 2012; 15:333-338.

275. Mohamed AA, Fares KM, Mohamed SA. Efficacy of intrathecally administered dexmedetomidine versus dexmedeto- midine with fentanyl in patients undergoing major abdominal cancer surgery. Pain Physician 2012; 15:339-348.

276. Manchikanti KN, Atluri S, Singh V, Geffert S, Sehgal N, Falco FJE. An update of evaluation of therapeutic thoracic facet joint interventions. Pain Physician 2012; 15:E463-E481.

277. Manchikanti L, Falco FJE, Benyamin RM, Caraway DL, Helm II, S, Wargo BW, Hansen H, Parr AT, Singh S, Hirsch JA. Assessment of infection control practices for interventional techniques: A best evidence synthesis of safe injection practices and use of single-dose medication vials. Pain Physician 2012; 15:E573E614.

278. Manchikanti L, Singh V, Caraway DL, Benyamin RM, Falco FJE, Hirsch JA. Proposed physician payment schedule for 2013: Guarded prognosis for interventional pain management. Pain Physician 2012; 15:E615-E627.

279. Meeus M, Nijs J, Hamers V, Ickmans K, Oosterwijck JV. The efficacy of patient education in whiplash associated disorders: a systematic review. Pain Physician 2012; 15:351-361.

280. Duarte RV, Raphael JH, Haque MS, Southall JL, Ashford RL. A predictive model for intrathecal opioid dose escalation for chronic non-cancer pain. Pain Physician 2012; 15:363-369.

281. Newmark JL, Mehra A, Singla AK. Radiocontrast media allergic reactions and interventional pain practice--a review. Pain Physician 2012; 15:E665-E675.

282. Andersen $\mathrm{LL}$, Andersen $\mathrm{CH}$, Sundstrup E, Jakobsen MD, Mortensen OS, Zebis MK. Central adaptation of pain perception in response to rehabilitation of musculoskeletal pain: randomized controlled trial. Pain Physician 2012; 15:385394.

283. Dupoiron D, Bore F, Lefebvre-Kuntz D, Brenet $\mathrm{O}$, Debourmont $\mathrm{S}$, Dixmerias F, Buisset N, Lebrec N, Monnin D. Ziconotide adverse events in patients with cancer pain: a multicenter observational study of a slow titration, multidrug protocol. Pain Physician 2012; 15:395-403.

284. Daenen L, Nijs J, Roussel N, Wouters K, Cras P. Altered perception of distorted visual feedback occurs soon after whiplash injury: an experimental study of central nervous system processing. Pain Physician 2012; 15:405-413.

285. Kim HJ, Park JH, Shin KM, Kang SS, Kim IS, Hong SJ, Song CK, Park JC, Yeom JS. The efficacy of transforaminal epidur- 
al steroid injection by the conventional technique in far-lateral herniation of lumbar disc. Pain Physician 2012; 15:415420.

286. Simopoulos TT, Manchikanti L, Singh V, Gupta S, Hameed H, Diwan S, Cohen SP. A systematic evaluation of prevalence and diagnostic accuracy of sacroiliac joint interventions. Pain Physician 2012; 15:E305-E344.

287. Kemp J, Despres O, Dufour A. Unreliability of the visual analog scale in experimental pain assessment: a sensitivity and evoked potentials study. Pain Physician 2012; 15:E693-E699.

288. Beall DP, Deer TR, Wilsey JT, Walsh AJ, Block JH, McKay WF, Zanella JM. Tissue distribution of clonidine following intraforaminal implantation of biodegradable pellets: potential alternative to epidural steroid for radiculopathy. Pain Physician 2012; 15:E701-E710.

289. Manchikanti L, Benyamin RM, Swicegood JR, Falco FJE, Datta S, Pampati V, Fellows B, Hirsch JA. Assessment of practice patterns of perioperative management of antiplatelet and anticoagulant therapy in interventional pain management. Pain Physician 2012; 15:E955E968.

290. Gupta S, Gupta M, Nath S, Hess GM. Survey of European pain medicine practice. Pain Physician 2012; 15:E983-E994.

291. Yi Y, Hwang BM, Son H, Cheong IY. Low bone mineral density, but not epidural steroid injection, is associated with fracture in postmenopausal women with low back pain. Pain Physician 2012; 15:441-449.

292. Deer TR, Kim C, Bowman R, Ranson MT, Yee BS. Study of percutaneous lumbar decompression and treatment algorithm for patients suffering from neurogenic claudication. Pain Physician 2012; 15:451-460.

293. Chon JY, Moon HS. Salivary cortisol concentration changes after epidural steroid injection. Pain Physician 2012; 15:461-466.

294. Kosturakis A, Gebhardt R. SynchroMed II intrathecal pump memory errors due to repeated magnetic resonance imaging. Pain Physician 2012; 15:475-477.

295. Sisk J, Palma M, Cooper C, Eltahawy E, Atallah J. Use of eptifibatide as a bridge antiplatelet agent for intrathecal drug delivery system placement. Pain Physician 2012; 15:479-483.

296. Heitzer E, Sandner-Kiesling A, Schippinger W, Stohscheer I, Osprian I, Bitsche S, Eisner F, Verebes J, Hof- mann G, Samonigg H. IL-7, IL-18, MCP1, MIP1-beta, and OPG as biomarkers for pain treatment response in patients with cancer. Pain Physician 2012; 15:499510.

297. Chang-Chien GC, Candido KD, Knezevic NN. Digital subtraction angiography does not reliably prevent paraplegia associated with lumbar transforaminal epidural steroid injection. Pain Physician 2012; 15:515-523.

298. Peng B, Fu X, Pang X, Li D, Liu W, Gao $\mathrm{C}$, Yang $\mathrm{H}$. Prospective clinical study on natural history of discogenic low back pain at 4 years of follow-up. Pain Physician 2012; 15:525-532.

299. Hansen H, Manchikanti L, Simopoulous TT, Christo PJ, Gupta S, Smith HS, Hameed $\mathrm{H}$, Cohen SP. A systematic evaluation of the therapeutic effectiveness of sacroiliac joint interventions. Pain Physician 2012; 15:E247-E278.

300. Wang W, Mei XP, Chen L, Tang J, Li JL, Wu SX, Xu LX, Li YQ. Triptolide Prevents and Attenuates Neuropathic Pain via Inhibiting Central Immune Response. Pain Physician 2012; 15:E995-E1006.

301. Helm S II, Benyamin RM, Chopra P, Deer TR, Justiz R. Percutaneous adhesiolysis in the management of chronic low back pain in post lumbar surgery syndrome and spinal stenosis: A systematic review. Pain Physician 2012; 15:E435-E462.

302. Helm II S, Colson J, Chopra P, Deer TR, Justiz R, Hameed M. Spinal endoscopic adhesiolysis in post lumbar surgery syndrome: An update of assessment of evidence. Pain Physician 2013; 16:SE125SE150.

303. Singh V, Manchikanti L, Calodney AK, Staats PS, Falco FJE, Caraway DL, Hirsch JA, Cohen SP. Percutaneous lumbar laser disc decompression: An update of current evidence. Pain Physician 2013; 16:229-SE260.

304. Manchikanti L, Singh V, Calodney AK, Helm II S, Deer TR, Benyamin RM, Falco FJE, Hirsch JA. Percutaneous lumbar mechanical disc decompression utilizing Dekompressor ${ }^{\circledR}$ : An update of current evidence. Pain Physician 2013; 16:SE1-SE24.

305. Manchikanti L, Singh V, Falco, FJE, Calodney AK, Onyewu O, Helm S, Benyamin R, Hirsch JA. An updated review of automated percutaneous mechanical lumbar discectomy for the contained herniated lumbar disc. Pain Physician 2013; 16:SE151-SE184.

306. Manchikanti L, Falco FJE, Benyamin
RM, Caraway DL, Deer TR, Singh V, Hameed $\mathrm{H}$, Hirsch JA. An update of the systematic assessment of mechanical lumbar disc decompression with nucleoplasty. Pain Physician 2013; 16:SE25SE54.

307. Helm SII, Deer TR, Manchikanti L, Datta S, Chopra P, Singh V, Hirsch JA. Effectiveness of thermal annular procedures in treating discogenic low back pain. Pain Physician 2012; 15:E279-E304.

308. Smith HS, Colson J, Sehgal N. An update of evaluation of intravenous sedation on diagnostic spinal injection procedures. Pain Physician 2013; 16:SE217SE228.

309. Falco FJE, Patel V, Geffert S, Zhu J, Onyewu O, Coubarous $S$, Justiz R, Smith HS. Intrathecal infusion systems for long-term management of chronic noncancer pain: An update of assessment of evidence. Pain Physician 2013; 16:SE185SE216.

310. Benyamin RM, Manchikanti L, Chiravuri S, Christo P, Deer TR, Falco FJE, Geffert $S$, Staats P, Barinidharan G. Spinal cord stimulation for patients with failed back surgery syndrome. Pain Physician 2013; 16:SE.

311. Manchikanti L, Benyamin RM, Singh V, Falco FJE, Hameed H, Derby R, Wolfer LR, Helm II S, Calodney AK, Datta S, Snook LT, Caraway DL, Hirsch JA, Cohen SP. An update of the systematic appraisal of the accuracy of utility of lumbar discography in chronic low back pain. Pain Physician 2013; 16:SE55-SE95.

312. Singh V, Manchikanti L, Onyewu O, Benyamin RM, Datta S, Geffert S, Parr AT, Falco FJE. An update of appraisal of accuracy of thoracic discography as a diagnostic test for chronic spinal pain. Pain Physician 2012; 15:E757-E775.

313. Onyewu O, Manchikanti L, Singh V, Geffert S, Helm II S, Hameed M, Falco FJE. An update of the appraisal of the accuracy and utility of cervical discography in chronic neck pain. Pain Physician 2012; 15:E777-E806.

314. Manchikanti L, Cash KA, Pampati V, Wargo BW, Malla Y. Cervical epidural injections in chronic discogenic neck pain without disc herniation or radiculitis: Preliminary results of a randomized, double-blind, controlled trial. Pain Physician 2010; 13:E265-E278.

315. Manchikanti L, Cash KA, Pampati V, Malla Y. Fluoroscopic cervical epidural injections in chronic axial or disc-related neck pain without disc herniation, facet joint pain, or radiculitis. J Pain Res 2012; 
5:227-236.

316. Manchikanti L, Cash KA, Pampati V, Wargo BW, Malla Y. The effectiveness of fluoroscopic cervical interlaminar epidural injections in managing chronic cervical disc herniation and radiculitis: Preliminary results of a randomized, double-blind, controlled trial. Pain Physician 2010; 13:223-236.

317. Manchikanti L, Cash KA, Pampati V, Wargo BW, Malla Y. Management of chronic pain of cervical disc herniation and radiculitis with fluoroscopic cervical interlaminar epidural injections. Int J Med Sci 2012; 9:424-434.

318. Manchikanti L, Malla Y, Cash KA, McManus CD, Pampati $V$. Fluoroscopic epidural injections in cervical spinal stenosis: Preliminary results of a randomized, double-blind, active control trial. Pain Physician 2012; 15:E59-E70.

319. Manchikanti L, Malla Y, Cash KA, McManus $C D$, Pampati V. Fluoroscopic cervical interlaminar epidural injections in managing chronic pain of cervical postsurgery syndrome: Preliminary results of a randomized, double-blind active control trial. Pain Physician 2012; 15:1326.

320. Manchikanti L, Buenaventura RM, Manchikanti KN, Ruan X, Gupta S, Smith HS, Christo PJ, Ward SP. Effectiveness of therapeutic lumbar transforaminal epidural steroid injections in managing lumbar spinal pain. Pain Physician 2012; 15: E199-E245.

321. Manchikanti L, Singh V, Cash KA, Pampati V, Falco FJE. The role of fluoroscopic interlaminar epidural injections in managing chronic pain of lumbar disc herniation or radiculitis: A randomized, double-blind trial. Pain Pract 2012 Dec. 27. [Epub ahead of print].

322. Parr AT, Manchikanti L, Hameed $\mathrm{H}$, Conn A, Manchikanti KN, Benyamin RM, Diwan S, Singh V, Abdi S. Caudal epidural injections in the management of chronic low back pain: A systematic appraisal of the literature. Pain Physician 2012; 15:E159-E198.

323. Manchikanti L, Cash KA, McManus CD, Pampati V, Benyamin R. Fluoroscopic lumbar interlaminar epidural injections in managing chronic lumbar axial or discogenic pain. J Pain Res 2012; 5:301311.

324. Manchikanti L, Cash KA, McManus CD, Damron KS, Pampati V, Falco FJE. Lumbar interlaminar epidural injections in central spinal stenosis: Preliminary results of a randomized, double-blind, active control trial. Pain Physician 2012; 15:51-63.

325. Manchikanti L, Cash KA, McManus CD, Pampati V, Benyamin RM. A preliminary report of a randomized double-blind, active controlled trial of fluoroscopic thoracic interlaminar epidural injections in managing chronic thoracic pain. Pain Physician 2010; 13:E357-E369.

326. Manchikanti L, Cash KA, McManus CD, Pampati V, Smith HS. One year results of a randomized, double-blind, active controlled trial of fluoroscopic caudal epidural injections with or without steroids in managing chronic discogenic low back pain without disc herniation or radiculitis. Pain Physician 2011; 14:25-36.

327. Manchikanti L, Cash KA, McManus CD, Pampati V. Fluoroscopic caudal epidural injections in managing chronic axial low back pain without disc herniation, radiculitis or facet joint pain. J Pain Res 2012; 5:381-390.

328. Manchikanti L, Singh V, Cash KA, Pampati V, Damron KS, Boswell MV. A randomized, controlled, double-blind trial of fluoroscopic caudal epidural injections in the treatment of lumbar disc herniation and radiculitis. Spine (Phila Pa 1976) 2011; 36:1897-1905.

329. Manchikanti L, Singh V, Cash KA, Pampati V, Damron KS, Boswell MV. Effect of fluoroscopically guided caudal epidural steroid or local anesthetic injections in the treatment of lumbar disc herniation and radiculitis: $A$ randomized, controlled, double blind trial with a two-year follow-up. Pain Physician 2012; 15:273-286.

330. Manchikanti L, Singh V, Cash KA, Pampati $\vee$, Datta S. Management of pain of post lumbar surgery syndrome: Oneyear results of a randomized, double double-blind, active controlled trial of fluoroscopic caudal epidural injections. Pain Physician 2010; 13:509-521.

331. Manchikanti L, Singh V, Cash KA, Pampati V, Datta S. Fluoroscopic caudal epidural injections in managing post lumbar surgery syndrome: Two-year results of a randomized, double-blind, activecontrol trial. Int J Med Sci 2012; 9:582-591.

332. Benyamin RM, Manchikanti L, Parr AT, Diwan SA, Singh V, Falco FJE, Datta S, Abdi S, Hirsch JA. The effectiveness of lumbar interlaminar epidural injections in managing chronic low back and lower extremity pain. Pain Physician 2012; 15:E363-E404.

333. Manchikanti L, Cash KA, McManus CD, Pampati V, Fellows B. Fluoroscopic cau- dal epidural injections with or without steroids in managing pain of lumbar spinal stenosis: One year results of randomized, double-blind, active-controlled trial. J Spinal Disord Tech 2012; 25:226-234.

334. Manchikanti L, Cash KA, McManus CD, Pampati $V$, Fellows B. Results of 2-year follow-up of a randomized, doubleblind, controlled trial of fluoroscopic caudal epidural injections in central spinal stenosis. Pain Physician 2012; 15:371384 .

335. Manchikanti L, Singh V, Falco FJE, Cash KA, Pampati V. Evaluation of lumbar facet joint nerve blocks in managing chronic low back pain: A randomized, doubleblind, controlled trial with a 2-year follow-up. Int ] Med Sci 2010; 7:124-135.

336. Manchikanti L, Singh V, Falco FJ, Cash KA, Fellows B. Cervical medial branch blocks for chronic cervical facet joint pain: A randomized double-blind, controlled trial with one-year follow-up. Spine (Phila Pa 1976) 2008; 33:1813-1820.

337. Manchikanti L, Singh V, Falco FJE, Cash KA, Fellows B. Comparative outcomes of a 2-year follow-up of cervical medial branch blocks in management of chronic neck pain: A randomized, double-blind controlled trial. Pain Physician 2010; 13:437-450.

338. Manchikanti L, Singh V, Falco FJE, Cash KA, Pampati V, Fellows B. The role of thoracic medial branch blocks in managing chronic mid and upper back pain: A randomized, double-blind, activecontrol trial with a 2-year follow-up. Anesthesiol Res Pract 2012; 2012:585806.

339. Manchikanti L, Boswell MV, Singh V, Pampati V, Damron KS, Beyer CD. Prevalence of facet joint pain in chronic spinal pain of cervical, thoracic, and lumbar regions. BMC Musculoskelet Disord 2004; 5:15.

340. Manchukonda R, Manchikanti KN, Cash KA, Pampati V, Manchikanti L. Facet joint pain in chronic spinal pain: An evaluation of prevalence and false-positive rate of diagnostic blocks. J Spinal Disord Tech 2007; 20:539-545.

341. Hawkins J, Schofferman J. Serial therapeutic sacroiliac joint injections: A practice audit. Pain Med 2009; 10:850-853.

342. Liliang $\mathrm{PC}$, Lu K, Weng $\mathrm{HC}$, Liang $\mathrm{CL}$, Tsai YD, Chen HJ. The therapeutic efficacy of sacroiliac joint blocks with triamcinolone acetonide in the treatment of sacroiliac joint dysfunction without spondyloarthropathy. Spine (Phila Pa 1976) 2009; 34:896-900. 
343. Kim WM, Lee HG, Jeong CW, Kim CM, Yoon $\mathrm{MH}$. A randomized controlled trial of intra-articular prolotherapy versus steroid injection for sacroiliac joint pain. J Altern Complement Med 2010; 16:12851290.

344. Borowsky CD, Fagen G. Sources of sacroiliac region pain: Insights gained from a study comparing standard intra-articular injection with a technique combining intra- and peri-articular injection. Arch Phys Med Rehabil 2008; 89:20482056.

345. Manchikanti L, Singh V, Cash KA, Pampati $V$, Datta S. A comparative effectiveness evaluation of percutaneous adhesiolysis and epidural steroid injections in managing lumbar post surgery syndrome: A randomized, equivalence controlled trial. Pain Physician 2009;

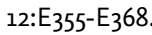

346. Heavner JE, Racz GB, Raj P. Percutaneous epidural neuroplasty: Prospective evaluation of $0.9 \% \mathrm{NaCl}$ versus $10 \%$ $\mathrm{NaCl}$ with or without hyaluronidase. Reg Anesth Pain Med 1999; 24:202-207.

347. Park $\mathrm{CH}$, Lee $\mathrm{SH}$, Jung JY. Dural sac cross-sectional area does not correlate with efficacy of percutaneous adhesiolysis in single level lumbar spinal stenosis. Pain Physician 2011; 14:377-382.

348. North RB, Kidd DH, Farrokhi F, Piantadosi SA. Spinal cord stimulation versus repeated lumbosacral spine surgery for chronic pain: A randomized, controlled trial. Neurosurgery 2005; 56:98-107.

349. Heidland A, Fazeli G, Klassen A, Sebekova $\mathrm{K}$, Hennemann $\mathrm{H}$, Bahner $\mathrm{U}$, Di lorio B. Neuromuscular electrostimulation techniques: historical aspects and current possibilities in treatment of pain and muscle waisting. Clin Nephrol 2013; 79):12-23.

350. Campbell CM, Jamison RN, Edwards RR. Psychological screening/phenotyping as predictors for spinal cord stimulation. Curr Pain Headache Rep 2013; 17:307.

351. Ultenius C, Song Z, Lin P, Meyerson BA, Linderoth B. Spinal GABAergic Mechanisms in the Effects of Spinal Cord Stimulation in a Rodent Model of Neuropathic Pain: Is GABA Synthesis Involved? Neuromodulation. 2012 Dec 14. [Epub ahead of print]

352. Vranken JH. Elucidation of pathophysiology and treatment of neuropathic pain. Cent Nerv Syst Agents Med Chem 2012; 12:304-314.

353. Moens M, Sunaert S, Mariën P, Brouns
R, De Smedt A, Droogmans S, Van Schuerbeek P, Peeters R, Poelaert J, Nuttin B. Spinal cord stimulation modulates cerebral function: an fMRI study. Neuroradiology 2012; 54:1399-1407.

354. Dias QM, Silveira JW, Reis GM, Costa KA, Rossaneis AC, Fais RS, Prado WA. The effect of intrathecal gabapentin on neuropathic pain is independent of the integrity of the dorsolateral funiculus in rats. Life Sci 2012; 91:837-842.

355. Pluijms WA, Slangen R, Bakkers M, Faber CG, Merkies IS, Kessels AG, Dirksen $C D$, Joosten EA, Reulen JP, van Dongen RT, Schaper NC, van Kleef M. Pain relief and quality-of-life improvement after spinal cord stimulation in painful diabetic polyneuropathy: a pilot study. $\mathrm{Br}$ ] Anaesth 2012; 109:623-629.

356. Nizard J, Raoul S, Nguyen JP, Lefaucheur JP. Invasive stimulation therapies for the treatment of refractory pain. Discov Med 2012; 14:237-246.

357. McGaraughty S, Chu KL, Cowart MD, Brioni JD. Antagonism of supraspinal histamine $\mathrm{H}_{3}$ receptors modulates spinal neuronal activity in neuropathic rats. J Pharmacol Exp Ther 2012; 343:13-20.

358. Yamaoka G, Horiuchi H, Morino T, Miura H, Ogata T. Different analgesic effects of adenosine between postoperative and neuropathic pain. J Orthop Sci. 2012 Sep 21. [Epub ahead of print]

359. Flagg A 2nd, McGreevy K, Williams K. Spinal cord stimulation in the treatment of cancer-related pain: "back to the origins". Curr Pain Headache Rep 2012; 16:343-349.

360. Barchini J, Tchachaghian S, Shamaa F, Jabbur SJ, Meyerson BA, Song Z, Linderoth B, Saadé NE. Spinal segmental and supraspinal mechanisms underlying the pain-relieving effects of spinal cord stimulation: an experimental study in a rat model of neuropathy. Neuroscience 2012; 215:196-208.

361. Smits $H$, van Kleef $M$, Holsheimer J, Joosten EA. Experimental Spinal Cord Stimulation and Neuropathic Pain: Mechanism of Action, Technical Aspects, and Effectiveness. Pain Pract 2012 Jul 11. [Epub ahead of print]

362. Münster T, Tiebel N, Seyer H, Maihöfner $C$. Modulation of somatosensory profiles by spinal cord stimulation in primary Raynaud's syndrome. Pain Pract 2012; 12:469-475.

363. Guan Y. Spinal cord stimulation: neurophysiological and neurochemical mechanisms of action. Curr Pain Headache
Rep 2012; 16:217-225

364. Wolter T, Kiemen A, Porzelius C, Kaube $\mathrm{H}$. Effects of sub-perception threshold spinal cord stimulation in neuropathic pain: a randomized controlled doubleblind crossover study. Eur J Pain 2012; 16:648-655.

365. Plow EB, Pascual-Leone A, Machado A. Brain stimulation in the treatment of chronic neuropathic and non-cancerous pain. J Pain 2012; 13:411-424.

366. Kapoor S. Pain management in postherpetic neuralgia: emerging new therapeutic options besides spinal cord stimulation. Neuromodulation 2012; 15:267.

367. Mailis A, Taenzer P. Evidence-based guideline for neuropathic pain interventional treatments: spinal cord stimulation, intravenous infusions, epidural injections and nerve blocks. Pain Res Manag 2012; 17:150-158.

368. Shanthanna $H$, Chan $P$, McChesney J, Paul J, Thabane L. Assessing the effectiveness of 'pulse radiofrequency treatment of dorsal root ganglion' in patients with chronic lumbar radicular pain: study protocol for a randomized control trial. Trials 2012; 13:52.

369. Shibuta K, Suzuki I, Shinoda M, Tsuboi Y, Honda K, Shimizu N, Sessle BJ, Iwata K. Organization of hyperactive microglial cells in trigeminal spinal subnucleus caudalis and upper cervical spinal cord associated with orofacial neuropathic pain. Brain Res 2012; 1451:74-86.

370. Hunter C, Davé N, Diwan S, Deer T. Neuromodulation of Pelvic Visceral Pain: Review of the Literature and Case Series of Potential Novel Targets for Treatment. Pain Pract 2012. [Epub ahead of print]

371. Yanamoto F, Murakawa K. The effects of temporary spinal cord stimulation (or spinal nerve root stimulation) on the management of early postherpetic neuralgia from one to six months of its onset. Neuromodulation 2012; 15:151-154; discussion 154.

372. Zeilhofer HU, Benke D, Yevenes GE. Chronic pain states: pharmacological strategies to restore diminished inhibitory spinal pain control. Annu Rev Pharmacol Toxicol 2012; 52:111-133.

373. Hama AT, Broadhead A, Lorrain DS, Sagen J. The antinociceptive effect of the asthma drug ibudilast in rat models of peripheral and central neuropathic pain. J Neurotrauma 2012; 29:600-610.

374. Moens M, Droogmans S, Spapen H, De Smedt A, Brouns R, Van Schuerbeek P, 
Luypaert R, Poelaert J, Nuttin B. Feasibility of cerebral magnetic resonance imaging in patients with externalised spinal cord stimulator. Clin Neurol Neurosurg 2012; 114:135-141.

375. Grau JW, Huie JR, Garraway SM, Hook MA, Crown ED, Baumbauer KM, Lee $\mathrm{KH}$, Hoy KC, Ferguson AR. Impact of behavioral control on the processing of nociceptive stimulation. Front Physiol 2012; 3:262.

376. Liu PY, Lu CL, Wang CC, Lee IH, Hsieh JC, Chen CC, Lee HF, Lin HC, Chang FY, Lee SD. Spinal microglia initiate and maintain hyperalgesia in a rat model of chronic pancreatitis. Gastroenterology 2012; 142:165-173.

377. Foreman RD, Linderoth B. Neural mechanisms of spinal cord stimulation. Int Rev Neurobiol 2012; 107:87-119.

378. Wolter T, Winkelmüller M. Continuous versus intermittent spinal cord stimulation: an analysis of factors influencing clinical efficacy. Neuromodulation 2012; 15:13-19; discussion 20.

379. Smits $H$, van Kleef M, Joosten EA. Spinal cord stimulation of dorsal columns in a rat model of neuropathic pain: evidence for a segmental spinal mechanism of pain relief. Pain 2012; 153:177-183.

380. Sarubbo S, Latini F, Tugnoli V, Quatrale R, Granieri E, Cavallo MA. Spinal anesthesia and minimal invasive laminotomy for paddle electrode placement in spinal cord stimulation: technical report and clinical results at long-term followup. ScientificWorldjournal 2012; 2012:201053.

381. Curto-Reyes V, Boto T, Hidalgo A, Menéndez L, Baamonde A. Antinociceptive effects induced through the stimulation of spinal cannabinoid type 2 receptors in chronically inflamed mice. Eur J Pharmacol 2011; 668:184-9.

382. Nguyen JP, Nizard J, Keravel Y, Lefaucheur JP. Invasive brain stimulation for the treatment of neuropathic pain. Nat Rev Neurol 2011; 7:699-709.

383. Kumar K, Rizvi S, Bnurs SB. Spinal cord stimulation is effective in management of complex regional pain syndrome 1 : fact or fiction. Neurosurgery 2011; 69:566578.

384. Williams KA, Gonzalez-Fernandez M, Hamzehzadeh S, Wilkinson I, Erdek MA, Plunkett A, Griffith S, Crooks M, Larkin T, Cohen SP. A multi-center analysis evaluating factors associated with spinal cord stimulation outcome in chronic pain patients. Pain Med 2011; 12:1142-
1153.

385. Coronel MF, Labombarda F, Roig P, Villar MJ, De Nicola AF, González SL. Progesterone prevents nerve injury-induced allodynia and spinal NMDA receptor upregulation in rats. Pain Med 2011; 12:1249-1261.

386. Abe K, Fujii Y, Nojima H. Evaluation of hyperalgesia in spared nerve injury model using mechanical, thermal, and chemical stimuli in the mouse. Neurol Res 2011; 33:656-662.

387. North RB, Kumar K, Wallace MS, Henderson JM, Shipley J, Hernandez J, Mekel-Bobrov N, Jaax KN. Spinal cord stimulation versus re-operation in patients with failed back surgery syndrome: an international multicenter randomized controlled trial (EVIDENCE study). Neuromodulation 2011; 14:330-335; discussion 335-336.

388. Truin $M$, van Kleef $M$, Linderoth $B$, Smits $\mathrm{H}$, Janssen SP, Joosten EA. Increased efficacy of early spinal cord stimulation in an animal model of neuropathic pain. Eur J Pain 2011; 15:111-117.

389. Dableh LJ, Yashpal K, Henry JL. Neuropathic pain as a process: reversal of chronification in an animal model. J Pain Res 2011; 4:315-23.

390. Aló KM, Abramova MV, Richter EO. Percutaneous peripheral nerve stimulation. Prog Neurol Surg 2011; 24:41-57.

391. Guan Y, Wacnik PW, Yang F, Carteret AF, Chung CY, Meyer RA, Raja SN. Spinal cord stimulation-induced analgesia: electrical stimulation of dorsal column and dorsal roots attenuates dorsal horn neuronal excitability in neuropathic rats. Anesthesiology 2010; 113:1392-1405.

392. Taylor RS, Taylor R, Fritzell P. Balloon kyphoplasty and vertebroplasty for vertebral compression fractures: A comparative systematic review of efficacy and safety. Spine (Phila Pa 1976) 2006; 31:2747-2755

393. Taylor RS, Fritzell P, Taylor RJ. Balloon kyphoplasty in the management of vertebral compression fractures: An updated systematic review and meta-analysis. Eur Spine ] 2007; 16:1085-1100.

394. Hulme PA, Krebs J, Ferguson SJ, Berlemann U. Vertebroplasty and kyphoplasty: A systematic review of 69 clinical studies. Spine (Phila Pa 1976) 2006; 31:1983-2001.

395. Ploeg WT, Veldhuizen AG, The B, Sietsma MS. Percutaneous vertebroplasty as a treatment for osteoporotic vertebral compression fractures: A systematic re- view. Eur Spine ] 2006; 15:1749-1758.

396. Buchbinder R, Osborne RH, Ebeling PR, Wark JD, Mitchell P, Wriedt C, Graves S, Staples MP, Murphy B. A randomized trial of vertebroplasty for painful osteoporotic vertebral fractures. $N$ Engl J Med 2009; 361:557-568.

397. Kallmes DF, Cornstock BA, Heagerty PJ, Turner JA, Wilson DJ, Diamond TH, Edwards R, Gray LA, Stout L, Owen S, Hollingworth W, Ghdoke B, Annesley-Williams DJ, Ralston SH, Jarvik JG. A randomized trial of vertebroplasty for osteoporotic spinal fractures. $N$ Engl ] Med 2009; 361:569-579.

398. Gill JB, Kuper M, Chin PC, Zhang Y, Schutt R Jr. Comparing pain reduction following kyphoplasty and vertebroplasty for osteoporotic vertebral compression fractures. Pain Physician 2007; 10:583-590.

399. Murphy AY, van Teijlingen ER, Gobbi MO. Inconsistent grading of evidence across countries: A review of low back pain guidelines. J Manipulative Physiol Ther 2006; 29:576-581.

40o. Manchikanti L, Singh V, Bakhit CE, Fellows $B$. Interventional techniques in the management of chronic pain. Part 1.0. Pain Physician 2000; 3:7-42.

401. Manchikanti L, Singh V, Kloth DS, Slipman CW, Jasper JF, Trescot AM, Varley KG, Atluri SL, Giron C, Curran MJ, Rivera JJ, Baha A, Bakhit CE, Reuter M. Interventional techniques in the management of chronic pain: Part 2.o. Pain Physician 2001; 4:24-96.

402. Manchikanti L, Staats $P$, Singh $V$, Schultz DM, Vilims BD, Jasper JF, Kloth DS, Trescot AM, Hansen HC, Falasca TD, Racz GB, Deer T, Burton AW, Helm S, Lou L, Bakhit CE, Dunbar EE, Atluri SL, Calodney AK, Hassenbusch S, Feler CA. Evidence-based practice guidelines for interventional techniques in the management of chronic spinal pain. Pain Physician 2003; 6:3-81.

403. Boswell MV, Shah RV, Everett CR, Sehgal N, Mckenzie-Brown AM, Abdi S, Bowman RC, Deer TR, Datta S, Colson JD, Spillane WF, Smith HS, LucasLevin LF, Burton AW, Chopra P, Staats PS, Wasserman RA, Manchikanti L. Interventional techniques in the management of chronic spinal pain: Evidencebased practice guidelines. Pain Physician 2005; 8:1-47.

404. Boswell MV, Trescot AM, Datta S, Schultz DM, Hansen HC, Abdi S, Sehgal N, Shah RV, Singh V, Benyamin RM, Patel VB, Buenaventura RM, Colson JD, Cord- 
ner HJ, Epter RS, Jasper JF, Dunbar EE, Atluri SL, Bowman RC, Deer TR, Swicegood JR, Staats PS, Smith HS, Burton AW, Kloth DS, Giordano J, Manchikant L. Interventional techniques: Evidencebased practice guidelines in the management of chronic spinal pain. Pain Physician 2007; 10:7-111.

405. Atluri S, Boswell MV, Hansen HC, Trescot AM, Singh V, Jordan AE. Guidelines for the use of controlled substances in the management of chronic pain. Pain Physician 2003; 6:233-257.

406. Trescot AM, Boswell MV, Atluri SL, Hansen HC, Deer TR, Abdi S, Jasper JF, Singh $V$, Jordan $A E$, Johnson BW, Cicala RS, Dunbar EE, Helm S, Varley KG, Suchdev PK, Swicegood JR, Calodney AK, Ogoke BA, Minore WS, Manchikanti L. Opioid guidelines in the management of chronic non-cancer pain. Pain Physician 2006; 9:1-40.

407. Trescot AM, Helm S, Hansen H, Benyamin R, Adlaka R, Patel S, Manchikanti L. Opioids in the management of chronic non-cancer pain: An update of American Society of Interventional Pain Physicians' (ASIPP) guidelines. Pain Physician 2008; 11:S5-S62.

408. U.S. Department of Health and Human Services. Agency for Healthcare Research and Quality. National Guideline Clearinghouse. Opioids in the management of chronic non-cancer pain: An update of American Society of the Interventional Pain Physicians' (ASIPP) guidelines, 2008. http://guidelines.gov/ content.aspx?id=12521

409. U.S. Department of Health and Human Services. Agency for Healthcare Research and Quality. National Guideline Clearinghouse. Comprehensive evidence-based guidelines for interventional techniques in the management of chronic spinal pain, 2009. http://guidelines.gov/content.aspx?id $=15136$

410. Shojania KG, Sampson M, Ansari MT, Ji J, Doucette S, Moher D. How quickly do systematic reviews go out of date? A survival analysis. Ann Intern Med 2007; 147:224-233.

411. Sampson M, Shojania KG, Garritty C, Horsley T, Ocampo M, Moher D. Systematic reviews can be produced and published faster. J Clin Epidemiol 2008; 61:531-536.

412. Shojania KG, Sampson M, Ansari MT, Ji J, Garritty C, Rader T, Moher D. Updating Systematic Reviews. Rockville (MD): Agency for Healthcare Research and Quality (US); 2007 Sep. Report No.: 07-
0087.AHRQ Technical Reviews.

413. Chung M, Newberry SJ, Ansari MT, Yu WW, Wu H, Lee J, Suttorp M, Gaylor JM, Motala A, Moher D, Balk EM, Shekelle PG. Two methods provide similar signals for the need to update systematic reviews. J Clin Epidemiol 2012; 65:660668.

414. Ollenschläger $G$, Marshall $C$, Qureshi $S$, Rosenbrand K, Burgers J, Mäkelä M, Slutsky J; Board of Trustees 2002, Guidelines International Network (G-I$\mathrm{N})$. Improving the quality of health care: Using international collaboration to inform guideline programmes by founding the Guidelines International Network (G-I-N). Qual Saf Health Care 2004; 13:455-460.

415. Sampson M, McGowan J, Cogo E, Grimshaw J, Moher D, Lefebvre C. An evidence-based practice guideline for the peer review of electronic search strategies. J Clin Epidemiol 2009; 62:944-952.

416. Sampson M, Shojania KG, McGowan J, Daniel R, Rader T, lansavichene AE, Ji J, Ansari MT, Moher D. Surveillance search techniques identified the need to update systematic reviews. J Clin Epidemiol 2008; 61:755-762.

417. Furlan AD, Pennick V, Bombardier $C$, van Tulder M; Editorial Board, Cochrane Back Review Group. 2009 updated method guidelines for systematic reviews in the Cochrane Back Review Group. Spine (Phila Pa 1976) 2009; 34:1929-1941.

418. Staal JB, de Bie R, de Vet HC, Hildebrandt J, Nelemans $P$. Injection therapy for subacute and chronic low-back pain. Cochrane Database Syst Rev 2008; 3:CDoo1824.

419. Wells GA, Shea B, O'Connell D, Peterson J, Welch V, Losos M, Tugwell P. The Newcastle-Ottawa Scale (NOS) for assessing the quality of nonrandomized studies in meta-analysis. www.ohri.ca/ programs/clinical_epidemiology/oxford.asp

420. Lucas N, Macaskill P, Irwig L, Moran R, Bogduk N. Reliability of physical examination for diagnosis of myofascial trigger points: A systematic review of the literature. Clin J Pain 2009; 25:80-89.

421. Manchikanti L, Derby R, Wolfer LR, Singh V, Datta S, Hirsch JA. Evidencebased medicine, systematic reviews, and guidelines in interventional pain management: Part 5. Diagnostic accuracy studies. Pain Physician 2009; 12:517-540.

422. Bossuyt PM, Reitsma JB, Bruns DE, Gatsonis CA, Glasziou PP, Irwig LM, Li- jmer JG, Moher D, Rennie D, de Vet HC; Standards for Reporting of Diagnostic Accuracy. Towards complete and accurate reporting of studies of diagnostic accuracy: The STARD Initiative. Ann Intern Med 2003; 138:40-44.

423. Whiting P, Rutjes A, Reitsma J, Bossuyt P, Kleijnen J. The development of QUADAS: A tools for the quality assessment of studies of diagnostic accuracy included in systematic reviews. BMC Med Res Methodol 2003; 3:25.

424. Whiting PF, Rutjes AW, Westwood ME, Mallett S, Deeks JJ, Reitsma JB, Leeflang MM, Sterne JA, Bossuyt PM; QUADAS-2 Group. QUADAS-2: A revised tool for the quality assessment of diagnostic accuracy studies. Ann Intern Med 2011; 155:529536.

425. Lucas NP, Macaskill P, Irwig L, Bogduk $N$. The development of a quality appraisal tool for studies of diagnostic reliability (QAREL). J Clin Epidemiol 2010; 63:854-861.

426. Singh $S$, Chang SM, Matchar DB, Bass EB. Chapter 7: Grading a body of evidence on diagnostic tests. J Gen Intern Med 2012; 27:47-55.

427. Lijmer JG, Mol BW, Heisterkamp S, Bonsel GJ, Prins $\mathrm{MH}$, van der Meulen $\mathrm{JH}$, Bossuyt PM. Empirical evidence of design-related bias in studies of diagnostic tests. JAMA 1999; 282:1061-1066.

428. Whiting $P$, Harbord R, Kleijnen J. No role for quality scores in systematic reviews of diagnostic accuracy studies. BMC Med Res Methodol 2005; 5:19.

429. Hestboek L, Leboeuf-Yde C. Are chiropractic tests for the lumbo-pelvic spine reliable and valid? A systematic critical literature review. J Manipulative Physiol Ther 2000; 23:258-275.

430. Hollerwoger D. Methodological quality and outcomes of studies addressing manual cervical spine examinations: A review. Man Ther 2006; 11:93-98.

431. May S, Littlewook C, Bishop A. Reliability of procedures used in the physical examination of non-specific low back pain: A systematic review. Aust J Physiother 2006; 52:91-102.

432. Stochkendahl MJ, Christensen HW, Hartvigsen J, Vach W, Haas M, Hestbaek L, Adams A, Bronfort G. Manual examination of the spine: A systematic critical literature review of reproducibility.] Manipulative Physiol Ther 2006; 29:475-485, 485.e1-10.

433. van Trijffel E, Anderegg Q, Bossuyt PM, Lucas C. Inter-examiner reliability of passive assessment of interver- 
tebral motion in the cervical and lumbar spine: A systematic review. Man Ther 2005; 10:256-269.

434. van Tulder M, Furlan A, Bombardier C, Bouter L; Editorial Board of the Cochrane Collaboration Back Review Group. Updated method guidelines for systematic reviews in the Cochrane Collaboration Back Review Group. Spine (Phila Pa 1976) 2003; 28:1290-1299.

435. Liberati A, Altman DG, TetzlaffJ, Mulrow C, Gøtzsche PC, loannidis JP, Clarke M, Devereaux PJ, Kleijnen J, Moher D. The PRISMA statement for reporting systematic reviews and meta-analyses of studies that evaluate health care interventions: Explanation and elaboration. Ann Intern Med 2009; 151:W65-W94.

436. Moher D, Cook DJ, Eastwood S, Olkin I, Rennie D, Stroup DF. Improving the quality of reports of meta-analyses of randomised controlled trials: The QUOROM statement. Quality of reporting of meta-analyses. Lancet 1999; 354:18961900.

437. Philips Z, Ginnelly L, Sculpher M, Claxton K, Golder S, Riemsma R, Woolacoot $\mathrm{N}$, Glanville J. Review of guidelines for good practice in decision-analytic modelling in health technology assessment. Health Technol Assess 2004; 8:iii-iv, ix-xi, 1-158.

438. Moher D, Hopewell S, Schulz KF, Montori V, Gøtzsche PC, Devereaux PJ, Elbourne D, Egger M, Altman DG. CONSORT 2010 explanation and elaboration: Updated guidelines for reporting parallel group randomised trials. BM] 2010; 340:c869.

439. Moher D, Schulz KF, Altman DG; CONSORT Group (Consolidated Standards of Reporting Trials). The CONSORT statement: Revised recommendations for improving the quality of reports of parallel-group randomized trials. J Am Podiatr Med Assoc 2001; 91:437-442.

440. Moher D, Schulz KF, Altman DG; CONSORT. The CONSORT statement: Revised recommendations for improving the quality of reports of parallel group randomized trials. BMC Med Res Methodol 2001; 1:2.

441. Vandenbroucke JP, von Elm E, Altman DG, Gøtzsche PC, Mulrow CD, Pocock SJ, Poole C, Schlesselman JJ, Egger M; STROBE Initiative. Strengthening the Reporting of Observational Studies in Epidemiology (STROBE): Explanation and elaboration. Ann Intern Med 2007; 147: W163-W194.

442. von Elm E, Altman DG, Egger M, Po- cock SJ, Gøtzsche PC, Vandenbroucke JP; STROBE Initiative. The Strengthening the Reporting of Observational Studies in Epidemiology (STROBE) Statement: Guidelines for reporting observational studies. Ann Intern Med 2007; 147:573-577.

443. Vandenbroucke JP, Von Elm E, Altman DG, Gøtzsche PC, Mulrow CD, Pocock SJ, Poole C, Schlesselman JJ, Egger M; Iniciativa STROBE. Strengthening the reporting of observational studies in epidemiology (STROBE): Explanation and elaboration. Gac Sanit 2009; 23:158.

444. Staal JB, de Bie R, de Vet HC, Hildebrandt J, Nelemans $P$. Injection therapy for subacute and chronic low back pain: An updated Cochrane review. Spine (Phila Pa 1976) 2009; 34:49-59.

445. American College of Occupational and Environmental Medicine (ACOEM) Chronic Pain. In Occupational Medicine Practice Guidelines: Evaluation and Management of Common Health Problems and Functional Recovery of Workers, Second Edition. American College of Occupational and Environmental Medicine Press, Elk Grove Village, 2008.

446. Manchikanti L, Singh V, Derby R, Schultz DM, Benyamin RM, Prager JP, Hirsch JA. Reassessment of evidence synthesis of occupational medicine practice guidelines for interventional pain management. Pain Physician 2008; 11:393482.

447. Manchikanti L, Singh V, Derby R, Helm S, Trescot AM, Staats PS, Prager JP, Hirsch JA. Review of occupational medicine practice guidelines for interventional pain management and potential implications. Pain Physician 2008; 11:271289.

448. Manchikanti L, Singh V, Helm S, Trescot AM, Hirsch JA. A critical appraisal of 2007 American College of Occupational and Environmental Medicine (ACOEM) practice guidelines for interventional pain management: $A n$ independent review utilizing AGREE, AMA, IOM, and other criteria. Pain Physician 2008; 11:291-310.

449. Chou R. Using evidence in pain practice: Part I: Assessing quality of systematic reviews and clinical practice guidelines. Pain Med 2008; 9:518-530.

450. Chou R. Using evidence in pain practice: Part II: Interpreting and applying systematic reviews and clinical practice guidelines. Pain Med 2008; 9:531-541.

451. Koes BW, Scholten RJ, Mens JM, Bouter LM. Efficacy of epidural steroid injec- tions for low-back pain and sciatica: A systematic review of randomized clinical trials. Pain 1995; 63:279-288.

452. Sanders SH, Harden RN, Benson SE, Vicente PJ. Clinical practice guidelines for chronic non-malignant pain syndrome patients II: An evidence-based approach. J Back Musc Rehabil 1999; 13:47-58.

453. van Tulder MWV, Koes BW, Bouter LM. Conservative treatment of acute and chronic nonspecific low back pain. A systematic review of randomized controlled trials of the most common interventions. Spine (Phila Pa 1976) 1997; 22:2128-2156.

454. Geurts JW, van Wijk RM, Stolker RJ, Groen GJ. Efficacy of radiofrequency procedures for the treatment of spinal pain: A systematic review of randomized clinical trials. Reg Anesth Pain Med 2001; 26:394-400.

455. Resnick DK, Choudhri TF, Dailey AT, Groff MW, Khoo L, Matz PG, Mummaneni P, Watters WC 3rd, Wang J, Walters BC, Hadley MN; American Association of Neurological Surgeons/Congress of Neurological Surgeons. Guidelines for the performance of fusion procedures for degenerative disease of the lumbar spine. Part 13: injection therapies, low-back pain, and lumbar fusion. J Neurosurg Spine 2005; 2:707-715.

456. Niemisto L, Kalso E, Malmivaara A, Seitsalo S, Hurri H. Cochrane Collaboration Back Review Group. Radiofrequency denervation for neck and back pain: $A$ systematic review within the framework of the Cochrane collaboration back review group. Spine (Phila Pa 1976) 2003, 28:1877-1888.

457. Levin $\mathrm{JH}$. Prospective, double-blind, randomized placebo-controlled trials in interventional spine: What the highest quality literature tells us. Spine J 2009; 9:690-703.

458. Bigos SJ, Boyer OR, Braen GR, Brown K, Deyo R. Acute Low Back Problems in Adults. Clinical Practice Guideline Number 4. AHCPR Publication No. 95-0642. Agency for Health Care Policy and Research, Public Health Service, US Department of Health and Human Services, Rockville, December 1994.

459. Carragee EJ, Hurwitz EL, Cheng I, Carroll LJ, Nordin M, Guzman J, Peloso P, Holm LW, Côté P, Hogg-Johnson S, van der Velde G, Cassidy JD, Haldeman S, Bone and Joint Decade 2000-2010 Task Force on Neck Pain and Its Associated Disorders. Treatment of neck pain: Injections and surgical interventions: Re- 
sults of the Bone and Joint Decade 2000-2010 Task Force on Neck Pain and Its Associated Disorders. Spine (Phila Pa 1976) 2008; 33:S153-S169.

460. Armon C, Argoff CE, Samuels J, Backonja MM; Therapeutics and Technology Assessment Subcommittee of the American Academy of Neurology. Assessment: Use of epidural steroid injections to treat radicular lumbosacral pain: Report of the Therapeutics and Technology Assessment Subcommittee of the American Academy of Neurology. Neurology 2007; 68:723-729.

461. Smith GC, Pell JP. Parachute use to prevent death and major trauma related to gravitational challenge: Systematic review of randomised controlled trials. Int J Prosthodont 2006; 19:126-128.

462. McLeod RS. Issues in surgical randomized controlled trials. World J Surg 1999; 23:1210-1214.

463. Solomon MJ, Laxamana A, Devore L, McLeod RS. Randomized controlled trials in surgery. Surgery 1994; 115:707-712.

464. Hardin WD Jr, Stylianos S, Lally KP. Evidence-based practice in pediatric surgery. J Pediatr Surg 1999; 34:908-912.

465. McCulloch P, Taylor I, Sasako M, Lovett B, Griffin D. Randomised trials in surgery: Problems and possible solutions. BM] 2002; 324:1448-1451.

466. International Conference on Harmonisation of Technical Requirements for Registration of Pharmaceuticals for Human Use. ICH Harmonised Tripartite Guideline. Choice of Control Group and Related Issues in Clinical Trials E1o. July 20, 2000.

467. Pasqualucci A, Varrassi G, Braschi A, Peduto VA, Brunelli A, Marinangeli $F$ Gori F, Colò F, Paladín A, Mojoli F. Epidural local anesthetic plus corticosteroid for the treatment of cervical brachial radicular pain: Single injection verus continuous infusion. Clin J Pain 2007; 23:551-557.

468. Pasqualucci A. Experimental and clinical studies about the preemptive analgesia with local anesthetics. Possible reasons of the failure. Minerva Anestesiol 1998 64:445-457.

469. Arner S, Lindblom U, Meyerson BA, Molander C. Prolonged relief of neuralgia after regional anesthetic block. A call for further experimental and systematic clinical studies. Pain 1990; 43:287-297.

470. Lavoie PA, Khazen T, Filion PR. Mechanisms of the inhibition of fast axonal transport by local anesthetics. Neuro- pharmacology 1989; 28:175-181.

471. Cassuto J, Sinclair R, Bonderovic M. Anti-inflammatory properties of local anesthetics and their present and potential clinical implications. Acta Anaesthesiol Scand 2006; 50:265-282.

472. Sato C, Sakai A, Ikeda Y, Suzuki H, Sakamoto $A$. The prolonged analgesic effect of epidural ropivacaine in a rat mode of neuropathic pain. Anesth Analg 2008; 106:313-320.

473. Tachihara H, Sekiguchi M, Kikuchi S, Konno S. Do corticosteroids produce additional benefit in nerve root infiltration for lumbar disc herniation. Spine (Phila Pa 1976) 2008; 33:743-747.

474. Cui W, Li Y, Li S, Wang R, Li J. Systemic administration of lidocaine reduces morphine requirements and postoperative pain of patients undergoing thoracic surgery after propofol-remifentanil based anaesthesia. Eur J Anaesthesiol 2010; 27:41-46.

475. Koppert W, Zeck S, Sittl R. Low dose lidocaine suppresses experimentally induced hyperalgesia in humans. Anesthesiology 1998; 89:1345-1353.

476. Koppert W, Ostermaier N, Sittl R, Weidner C, Schmelz M. Low dose lidocaine reduces secondary hyperalgesia by a central mode of action. Pain 2000; 85:217-224.

477. Kawamata M, Takahashi T, Kozuka Y, Nawa Y, Nishikawa K, Narimatsu E, Watanabe $H$, Namiki A. Experimental incision induced pain in human skin: effects of systemic lidocaine on flare formation and hyperalgesia. Pain 2002; 100:77-89.

478. Hollmann MW, Durieux M. Local anesthetics and the inflammatory response. Anesthesiology 2000; 93:858-875.

479. Sugimoto M, Uchida I, Mashimoto T. Local anaesthetics have different mechanisms and sites of action at the recombinant NMDA receptors. $\mathrm{Br}$ J Pharmaco 2003; 138:876-882.

480. Lehmann LJ, Pallares VS. Subdural injection of a local anesthetic with steroids: complication of epidural anesthesia. South Med J 1995; 88:467-469.

481. Wittenberg RH, Greskötter KR, Steffen $R$, Schoenfeld BL. Is epidural injection treatment with hypertonic saline solution in intervertebral disk displacement useful? (The effect of $\mathrm{NaCl}$ solution on intervertebral disk tissue). Z Orthop Ihre Grenzgeb 1990; 128:223-226.

482. Mao J, Chen LL. Systemic lidocaine for neuropathic pain relief. Pain 2000; 87:7-17
483. Melzack R, Coderre TJ, Katz J, Vaccarino AL. Central neuroplasticity and pathological pain. Ann N Y Acad Sci 2001; 933:157-174.

484. Onda A, Yabuki S, Kikuchi S, Satoh K, Myers RR. Effects of lidocaine on blood flow and endoneurial fluid pressure in a rat model of herniated nucleus pulposus. Spine (Phila Pa 1976) 2001; 26:21862191.

485. Ohtori S, Inoue G, Koshi T, Ito T, Doya $\mathrm{H}$, Saito T, Moriya H, Takahashi K. Upregulation of acid-sensing ion channel 3 in dorsal root ganglion neurons following application of nucleus pulposus on nerve root in rats. Spine (Phila Pa 1976) 2006; 31:2048-2052.

486. Murata Y, Onda A, Rydevik B, Takahashi K, Olmarker K. Distribution and appearance of tumor necrosis factor-alpha in the dorsal root ganglion exposed to experimental disc herniation in rats. Spine (Phila Pa 1976) 2004; 29:2235-2241.

487. Kato K, Kikuchi S, Konno S, Sekiguchi M. Participation of 5-hydroxytryptamine in pain-related behavior induced by nucleus pulposus applied on the nerve root in rats. Spine (Phila Pa 1976) 2008; 33:1330-1336.

488. Kim SJ, Kim WR, Kim HS, Park HW, Cho YW, Jang SH, Hwang SJ, Ahn SH. Abnormal spontaneous activities on needle electromyography and their relation with pain behavior and nerve fiber pathology in a rat model of lumbar disc herniation. Spine (Phila Pa 1976) 2011; 36:E1562-E1567.

489. Takebayashi T, Cavanaugh JM, Cüneyt Ozaktay A, Kallakuri S, Chen C. Effect of nucleus pulposus on the neural activity of dorsal root ganglion. Spine (Phila $\mathrm{Pa}$ 1976) 2001; 26:940-945.

490. Otoshi K, Kikuchi S, Kato K, Sekiguchi M, Konno S. Anti-HMGBi neutralization antibody improves pain-related behavior induced by application of autologous nucleus pulposus onto nerve roots in rats. Spine (Phila Pa 1976) 2011; 36:E692-E698.

491. Zhang KB, Zheng ZM, Liu H, Liu XG. The effects of punctured nucleus pulposus on lumbar radicular pain in rats: A behavioral and immunohistochemical study. J Neurosurg Spine 2009; 11:492500.

492. Zhang JJ, Song W, Luo WY, Wei M, Sun LB, Zou XN, Liao WM. Autologous nucleus pulposus transplantation to lumbar 5 dorsal root ganglion after epineurium dissection in rats: A modified model of non-compressive lumbar her- 
niated intervertebral disc. Chin Med J (Engl) 2011; 124:2009-2014.

493. Gerszten PC, Smuck M, Rathmell JP, Simopoulos TT, Bhagia SM, Mocek CK, Crabtree T, Bloch DA; SPINE Study Group. Plasma disc decompression compared with fluoroscopy-guided transforaminal epidural steroid injections for symptomatic contained lumbar disc herniation: A prospective, randomized, controlled trial. J Neurosurg Spine 2010; 12:357-371.

494. Nath S, Nath CA, Pettersson K. Percutaneous lumbar zygapophysial (facet) joint neurotomy using radiofrequency current, in the management of chronic low back pain. A randomized double-blind trial. Spine (Phila Pa 1976) 2008; 33:12911297.

495. Van Kleef M, Barendse GA, Kessels A, Voets HM, Weber WE, de Lange S. Randomized trial of radiofrequency lumbar facet denervation for chronic low back pain. Spine (Phila Pa 1976) 1999; 24:19371942.

496. Lord SM, Barnsley L, Wallis BJ, McDonald GJ, Bogduk N. Percutaneous radiofrequency neurotomy for chronic cervical zygapophyseal-joint pain. $N$ Engl J Med 1996; 335:1721-1726.

497. McDonald GJ, Lord SM, Bogduk N. Long-term follow-up of patients treated with cervical radiofrequency neurotomy for chronic neck pain. Neurosurgery 1999; 45:61-68.

498. Dreyfuss $P$, Halbrook B, Pauza K, Joshi A, McLarty J, Bogduk N. Efficacy and validity of radiofrequency neurotomy for chronic lumbar zygapophysial joint pain. Spine (Phila Pa 1976) 2000; 25:12701277.

499. Barnsley L. Percutaneous radiofrequency neurotomy for chronic neck pain: Outcomes in a series of consecutive patients. Pain Med 2005; 6:282-286.

500. Lotz JC. Trials of vertebroplasty for vertebral fractures. N Engl J Med 2009; 361:2098.

501. Grey A, Bolland M. Trials of vertebroplasty for vertebral fractures. N Engl J Med 2009; 361:2098-2099.

502. Clark W, Lyon S, Burnes J. Trials of vertebroplasty for vertebral fractures. $N$ Engl] Med 2009; 361:2097-2098.

503. Baerlocker MO, Munk PL, Liu DM. Trials of vertebroplasty for vertebral fractures. N Engl] Med 2009; 361:2098.

504. Hróbjartsson A, Kaptchuk TJ, Miller FG. Placebo effect studies are susceptible to response bias and to other types of bias- es. J Clin Epidemiol 2011; 64:1223-1229.

505. Beecher HK. The powerful placebo. J Am Med Assoc 1955; 159:1602-1606.

506. Hróbjartsson A. What are the main methodological problems in the estimation of placebo effects. J Clin Epidemiol 2002; 55:430-435.

507. Kienle GS, Kiene H. The powerful placebo effect: Fact or fiction?] Clin Epidemiol 1997; 50:1311-1318.

508. Krogsbøll LT, Hróbjartsson A, Gøtzsche PC. Spontaneous improvement in randomised clinical trials: Meta-analysis of three-armed trials comparing no treatment, placebo and active intervention. BMC Med Res Methodol 2009; 9:1.

509. Hróbjartson A, Gotzsche PC. Is the placebo powerless? An analysis of clinical trials comparing placebo with no treatment. N Eng J Med 2001; 344:1594-1602.

510. Brody H, Weismantel D. A challenge to core beliefs. Adv Mind Body Med 2001; 17:296-298.

511. Miller FG, Colloca L, Kaptchuk TJ. The placebo effect: Illness and interpersonal healing. Perspectives Bio Med 2009; 52:518-539.

512. Kolata G. Placebo effect is more myth than science, study says. The New York Times May 24, 2001. www.nytimes. $\mathrm{com} / 2001 / 05 / 24 /$ us/placebo-effect-ismore-myth-than-science-study-says. html

513. Hróbjartson A, Gotzsche PC. Is the placebo powerless? Update of a systematic review with 52 new randomized trials comparing placebo with no treatment. J Intern Med 2004; 256:91-100.

514. Hróbjartsson A, Gøtzsche PC. Placebo interventions for all clinical conditions. Cochrane Database Syst Rev 2010; 1:CDoo3974.

515. Meissner K, Höfner L, Fässler M, Linde K. Widespread use of pure and impure placebo interventions by GPs in Germany. Fam Pract 2012; 29:79-85.

516. Carette S, Marcoux S, Truchon R, Grondin C, Gagnon J, Allard Y, Latulippe M. A controlled trial of corticosteroid injections into facet joints for chronic low back pain. N Engl ] Med 1991; 325:10021007 .

517. Carette S, Leclaire R, Marcoux S, Morin F, Blaise GA, St-Pierre A, Truchon R, Parent $F$, Levesque J, Bergeron $V$, Montminy $\mathrm{P}$, Blanchette $\mathrm{C}$. Epidural corticosteroid injections for sciatica due to herniated nucleus pulposus. $N$ Engl J Med 1997; 336:1634-1640.

518. Karppinen J, Malmivaara A, Kurunlahti
M, Kyllonen E, Pienimaki T, Nieminen P, Ohinmaa A, Tervonen O, Vanharanta $H$. Periradicular infiltration for sciatica: A randomized controlled trial. Spine (Phila Pa 1976) 2001; 26:1059-1067.

519. Manchikanti L, Giordano J, Fellows B, Hirsch JA. Placebo and nocebo in interventional pain management: $A$ friend or a foe - or simply foes? Pain Physician 2011; 14:E157-E175.

520. Kang YM, Choi WS, Pickar JG. Electrophysiologic evidence for an intersegmental reflex pathway between lumbar paraspinal tissues. Spine (Phila Pa 1976) 2002; 27:E56-E63.

521. Pham Dang C, Lelong A, Guilley J, Nguyen JM, Volteau C, Venet G, Perrier C, Lejus C, Blanloeil Y. Effect on neurostimulation of injectates used for perineural space expansion before placement of a stimulating catheter: Normal saline versus dextrose $5 \%$ in water. Reg Anesth Pain Med 2009; 34:398-403.

522. Tsui BC, Kropelin B, Ganapathy S, Finucane B. Dextrose $5 \%$ in water: Fluid medium maintaining electrical stimulation of peripheral nerve during stimulating catheter placement. Acta Anaesthesiol Scand 2005; 49:1562-1565.

523. Indahl A, Kaigle AM, Reikeras O, Holm $\mathrm{SH}$. Interaction between the porcine lumbar intervertebral disc, zygapophysial joints, and paraspinal muscles. Spine (Phila Pa 1976) 1997; 22:2834-2840.

524. Indahl A, Kaigle A, Reikeras O, Holm S. Electromyographic response of the porcine multifidus musculature after nerve stimulation. Spine (Phila Pa 1976) 1995; 20:2652-2658.

525. Bhatia MT, Parikh LCJ. Epidural saline therapy in lumbo-sciatic syndrome. J Indian Med Assoc 1966; 47:537-542.

526. Gupta AK, Mital VK, Azmi RU. Observations of the management of lumbosciatic syndromes (sciatica) by epidural saline. J Indian Med Assoc 1970; 54:194-196.

527. Smuck M, Levin JH. RE: Manchikanti L, Singh V, Falco FJE, Cash KA, Fellows B. Cervical medial branch blocks for chronic cervical facet joint pain: A randomized double-blind, controlled trial with one-year follow-up. Spine (Phila Pa 1976) 2008; 33:1813-1820. Spine (Phila Pa 1976) 2009; 34:1116-1117.

528. Manchikanti L, Shah RV, Datta S, Singh V. Critical evaluation of interventional pain management literature provides inaccurate conclusions. Spine J 2009; 9:706-708.

529. Egsmose C, Lund B, Bach Andersen R. Hip joint distension in osteoarthrosis. $A$ 
triple-blind controlled study comparing the effect of intra-articular indoprofen with placebo. Scand J Rheumatol 1984; 13:238-242.

530. Häuser W, Bartram C, Bartram-Wunn E, Tölle T. Adverse events attributable to nocebo in randomized controlled drug trials in fibromyalgia syndrome and painful diabetic peripheral neuropathy: Systematic review. Clin J Pain 2012; 28:437-451.

531. Lyby PS, Forsberg JT, Asli O, Flaten MA. Induced fear reduces the effectiveness of a placebo intervention on pain. Pain 2012; 153:1114-1121.

532. Louhiala P, Puustinen R. Rethinking the placebo effect. J Med Ethics 2008; 34:107109.

533. Louhiala P. The ethics of the placebo in clinical practice revisited. J Med Ethics 2009; 35:407-409.

534. Concato J. When to randomize, or "Evidence-based medicine needs medicine-based evidence." Pharmacoepidemiol Drug Saf 2012; 21:6-12.

535. Manchikanti L, Pampati V, Damron KS. The role of placebo and nocebo effects of perioperative administration of sedatives and opioids in interventional pain management. Pain Physician 2005; 8:349-355.

536. Grigoras A, Lee P, Sattar F, Shorten G. Perioperative intravenous lidocaine de- creases the incidence of persistent pain after breast surgery. Clin J Pain 2012; 28:567-572.

537. Gelijns AC, Gabriel SE. Looking beyond translation--integrating clinical research with medical practice. $N$ Engl J Med 2012; 366:1659-1661.

538. Quill TE, Holloway RG. Evidence, preferences, recommendations--finding the right balance in patient care. $N$ Engl J Med 2012; 366:1653-1655.

539. Blease C. The principle of parity: The "placebo effect" and physician communication. J Med Ethics 2012; 38:199-203.

540. Bisby MA. Inhibition of axonal transport in nerves chronically treated with local anesthetics. Exp Neurol 1975; 47:481-489.

541. Livingston EH, McNutt RA. The hazards of evidence-based medicine: Assessing variations in care. JAMA 2011; 306:762763.

542. Higgins JP, Thompson SG, Deeks JJ, Altman DG. Measuring inconsistency in meta-analyses. BM] 2003; 327:557-560.

543. DerSimonian R, Laird N. Meta-analysis in clinical trials. Control Clin Trials 1986; 7:177-188.

544. Harbord R, Higgins J. METAREG: Stata module to perform meta-analysis regression. Boston College Department of Economics, Boston, MA. http://econ- papers.repec.org/software/bocbocode/ s446201.htm

545. Farrar JT. What is clinically meaningful: Outcome measures in pain clinical trials. Clin J Pain 2000; 16:S106-S112.

546. Salaffi F, Stancati A, Silvestri CA, Ciapetti A, Grassi W. Minimal clinically important changes in chronic musculoskeletal pain intensity measured on a numerical rating scale. Eur J Pain 2004; 8:283-291.

547. Bombardier C. Outcome assessments in the evaluation of treatment of spinal disorders: Summary and general recommendations. Spine (Phila Pa 1976) 2000; 25:3100-3103.

548. Hagg O, Fritzell P, Nordwall A. The clinical importance of changes in outcome scores after treatment for chronic low back pain. Eur Spine ] 2003; 12:12-20.

549. Soer R, Reneman MF, Vroomen PC, Stegeman P, Coppes MH. Responsiveness and minimal clinically important change of the pain disability index in patients with chronic back pain. Spine (Phila Pa 1976) 2012; 37:711-715.

550. Harris RP, Helfand M, Woolf SH, Lohr KN, Mulrow CD, Teutsch SM, Atkins D; Methods Work Group, Third US Preventive Services Task Force. Current methods of the US Preventive Services Task Force. Am J Prevent Med 2001; 20:21-35. 